\title{
2-Chloroquinoline-3-carbaldehydes: synthesis, reactions and applications
}

\author{
Bakr F. Abdel-Wahab, ${ }^{\text {a }}$ Rizk E. Khidre,, $*$ Abdelbasset A. Farahat, ${ }^{\text {d }}$ \\ and Abdel-Aziz Sayed El-Ahl ${ }^{\mathbf{e}}$ \\ ${ }^{a}$ Applied Organic Chemistry department, National Research Centre, Dokki, \\ 12622 Giza, Egypt \\ ${ }^{b}$ Chemical Industries Division, National Research Centre, Dokki, 12622 Giza, Egypt \\ ${ }^{c}$ Chemistry department, Faculty of Science, Jazan University, Saudi Arabia \\ ${ }^{d}$ Department of Pharmaceutical Organic Chemistry, Faculty of Pharmacy, \\ Mansoura University, Mansoura 35516, Egypt \\ ${ }^{e}$ Chemistry Department, University College Makkah, Umm Al-Qura University, Kingdom of \\ Saudi Arabia \\ E-mail: rizkkhidre@yahoo.com
}

\begin{abstract}
This review summarizes the synthetic methods, reactions and biological applications of 2chloroquinoline-3-carbaldehydes during the period from 1999 to 2011. The reactions are subdivided in groups that cover reactions at the chloro or aldehyde substituent and reactions which involve both groups. Most reaction types have been successfully applied and used in the production of biological active compounds.
\end{abstract}

Keywords: Vilsmeier-Haack reaction, quinolines, aldehydes

\section{Table of Contents}

1. Introduction

2. Synthetic Methods

2.1. Vilsmeier-Haack reaction

2.2. Oxidation of the corresponding alcohols

3. Chemical Reactions

3.1. Substitution reactions

3.2. Addition reactions at the aldehyde group

3.3. Reduction of the aldehyde group

3.4. Condensation reactions

3.4.1. Reactions with active methylene compounds 
3.4.2. Reactions with hydrazine, hydroxylamine, hydrazides, (thio)semicarbazide, and urea 3.4.3. Reactions with amines and amides

3.4.4. Miscellaneous reactions

\section{Conclusions}

5. References

\section{Introduction}

Interesting pharmacological properties have been associated with 2-chloroquinoline-3carbaldehydes and their derivatives. ${ }^{1,2}$ These compounds have shown antimicrobial, ${ }^{1-3}$ antimalarial, ${ }^{4,5}$ anti-inflammatory, ${ }^{6-9}$ antitumor, ${ }^{10,11}$ and anti-parasitic activity. ${ }^{12}$ Despite this versatile importance, and in connection to our previous review articles about biologically active heterocyclic systems, ${ }^{13}$ 2-chloroquinoline-3-carbaldehydes have not been previously reviewed. The main objective of the present survey is to provide the synthesis, reactions, and biological applications of 2-chloroquinoline-3-carbaldehydes from 1999 to the end of 2011 and provide useful and up-to-date data for organic and medicinal chemists.

\section{Synthetic Methods}

There have been a number of practically important routes to synthesise of 2-chloroquinoline-3carbaldehydes, e.g. (i) Vilsmeier-Haack reaction of acetanilides, (ii) oxidation of the corresponding alcohols.

\subsection{Vilsmeier-Haack reaction}

2-Chloroquinoline-3-carbaldehydes 2 were synthesized from acetanilides $\mathbf{1}$ via a VilsmeierHaack reaction either by traditional methods ${ }^{14-23}$ or by microwave, ${ }^{24}$ or ultrasonic irradiation (Scheme 1). ${ }^{25}$

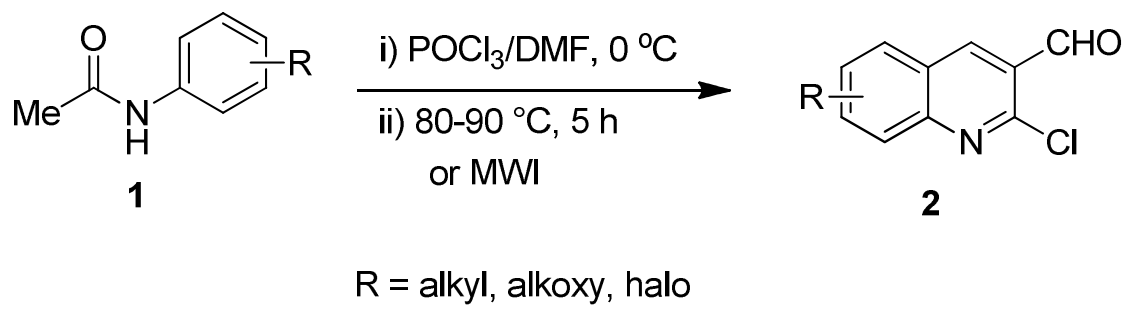

\section{Scheme 1}




\subsection{Oxidation of the corresponding alcohols}

(2-Chloroquinolin-3-yl)methanol $\mathbf{3}$ was oxidized to aldehyde $\mathbf{2}$ using a combination of diethyl diazene-1,2-dicarboxylate (DEAD) and catalytic $\mathrm{ZnBr}_{2}$ in refluxing toluene (Scheme 2). ${ }^{26}$

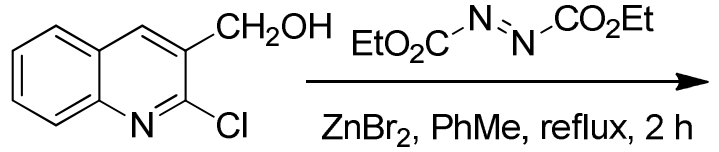

3<smiles>O=Cc1cc2ccccc2nc1Cl</smiles>

2

$86 \%$

\section{Scheme 2}

\section{Chemical Reactions}

\subsection{Substitution reactions}

Treatment of 2-chloroquinoline-3-carbaldehydes 2 with prenyl thiolate or prenyl alcoholate 4 in the presence of sodium hydroxide or potassium $t$-butoxide, furnished $S / O$-prenyl aldehydes $\mathbf{5}$ in $72-84 \%$ yield, respectively. $S / O$-prenyl aldehyde 5, underwent imino Diels-Alder reactions with various substituted anilines in the presence of $\mathrm{InCl}_{3}$ in acetonitrile resulting in the formation mixture of cis and trans products $\mathbf{7}$ and $\mathbf{8}$ in $55-71 \%$ yields by intramolecular cycloaddition reaction of the imine 6 generated in situ in the one pot-reaction (Scheme 3). ${ }^{14}$

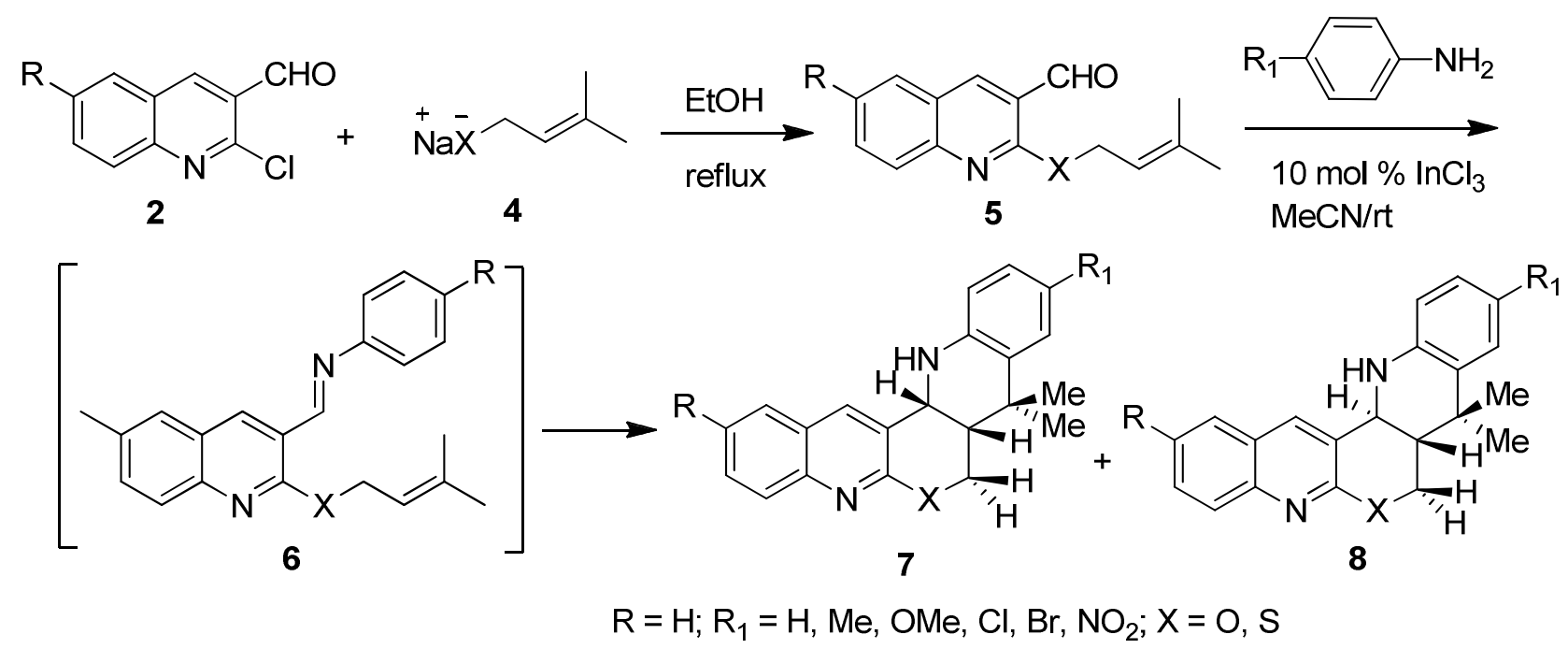

\section{Scheme 3}

Knoevenagel hetero Diels-Alder reaction of $5(\mathrm{X}=\mathrm{O})$ with $N, N^{\prime}$-dimethylbarbituric acid in water was carried out in the presence of piperidine at room temperature. The intermediate 
Knoevenagel adduct 9 was not isolated and allowed to cyclise at room temperature after $3 \mathrm{~h}$ stirring gave the cis-fused pentacyclic pyrano[2,3-b]quinoline derivatives $\mathbf{1 0}$ with high yield $(80 \%)$ and diastereoselectivity $(>99 \%)($ Scheme 4$){ }^{27}$

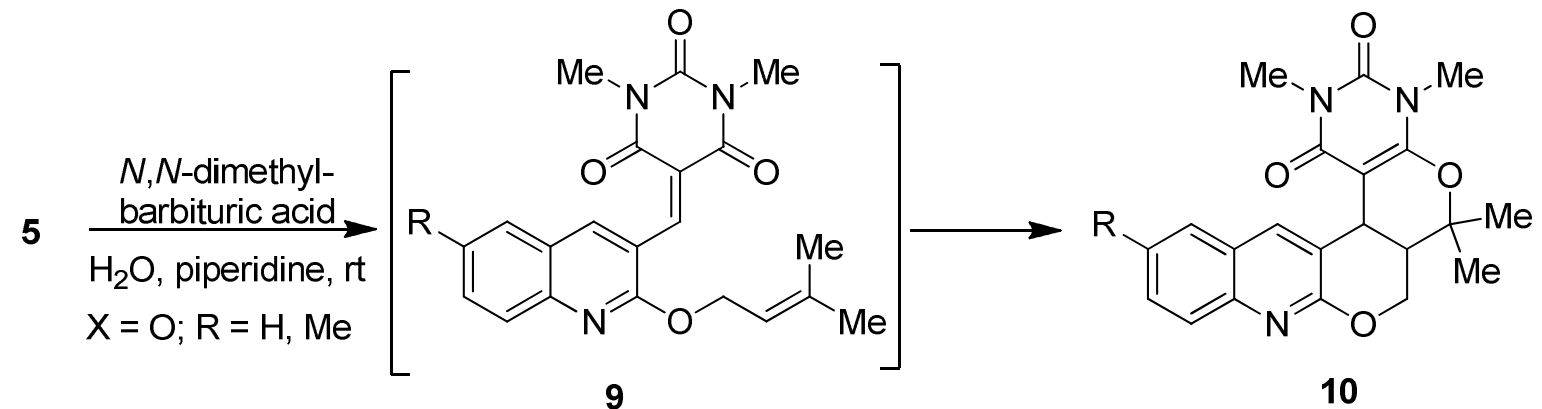

\section{Scheme 4}

Recently, tetrahydrocyclopenta[c]acridines $\mathbf{1 4}$ were synthesized from reaction of substituted aldehyde $\mathbf{2}$ with alkyne $\mathbf{1 1}$ in DMF in the presence of $\mathrm{Et}_{3} \mathrm{~N}$ to afford alkynyl quinolines $\mathbf{1 2}$ which were reacted with allyl magnesium bromide followed by Pauson-Khand cyclization using $\mathrm{Co}_{2}(\mathrm{CO})_{8}$ (Scheme 5). The synthesized compounds were used as kinase inhibitors in particular for treating cancer. ${ }^{11,12}$

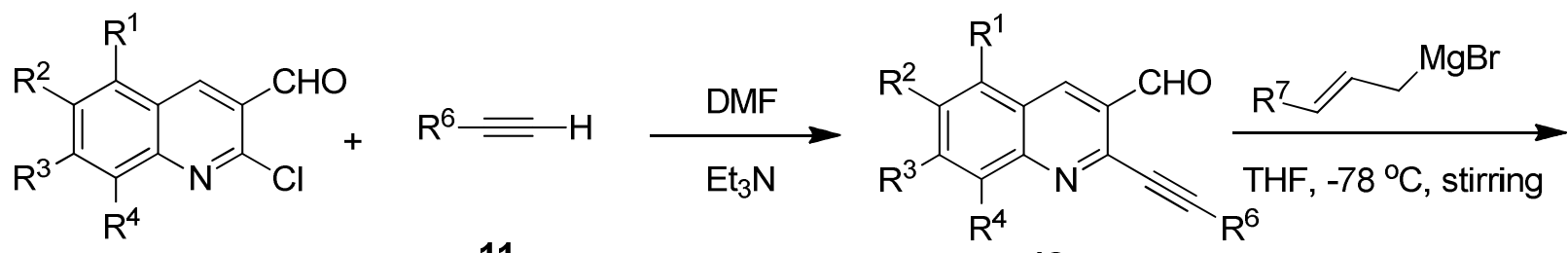

2

11

12<smiles>[R]C#Cc1nc2c([R4])c([R])c([R])c([R])c2cc1C([R8])CC=C[R]</smiles>

13

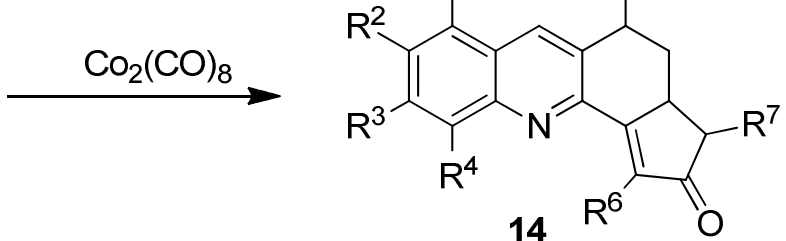

14

$R^{1}-R^{4}=H$, ether or polyether moiety, $N_{2}$, etc.; $R^{5}=O H$, halo, etc.; $R^{5}, R^{7}$, $=\mathrm{H}, \mathrm{C} 1-12$ alkyl; $\mathrm{R}^{6}=\mathrm{H}$, (un)substituted aryl, heteroaryl, etc.

\section{Scheme 5}


Similarly, a convenient and one-pot synthesis of 1-methoxy-3-phenyl-1H-pyrano[4,3- $b]$ quinoline $\mathbf{1 5}$ from reaction of aldehyde 2 with phenyl acetylene $\mathbf{1 1}\left(\mathrm{R}_{6}=\mathrm{Ph}\right)$ in acetonitrile in the presence of $\mathrm{Pd}(\mathrm{OAc})_{2}$ and triphenylphosphine was reported (Scheme 6). ${ }^{28}$<smiles>O=Cc1cc2ccccc2nc1Cl</smiles>

2

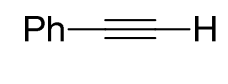

11

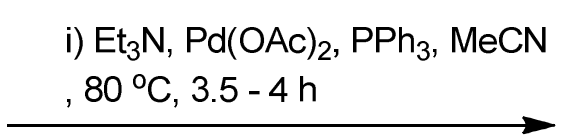

ii) $\mathrm{MeOH}, 80^{\circ} \mathrm{C}, 2-2.5 \mathrm{~h}$<smiles>COC1OC(c2ccccc2)=Cc2nc3ccccc3cc21</smiles>

$15,76 \%$

\section{Scheme 6}

Reaction of aldehydes 2 with phenylacetylene $\mathbf{1 1}\left(\mathrm{R}_{6}=\mathrm{Ph}\right)$ was carried out in the presence of $\mathrm{PdCl}_{2}$, triphenylphosphine, and triethylamine in acetonitrile at $80{ }^{\circ} \mathrm{C}$ under an inert atmosphere to give 2-(phenylethynyl)quinoline-3-carbaldehydes $\mathbf{1 6}$ in $87 \%$ yield. ${ }^{29-31}$ The later compounds were reacted with aqueous ammonia to afford 3-phenylbenzo[b][1,6]naphthyridine $\mathbf{1 7}$ in $88 \%$ yield (Scheme 7). ${ }^{31}$

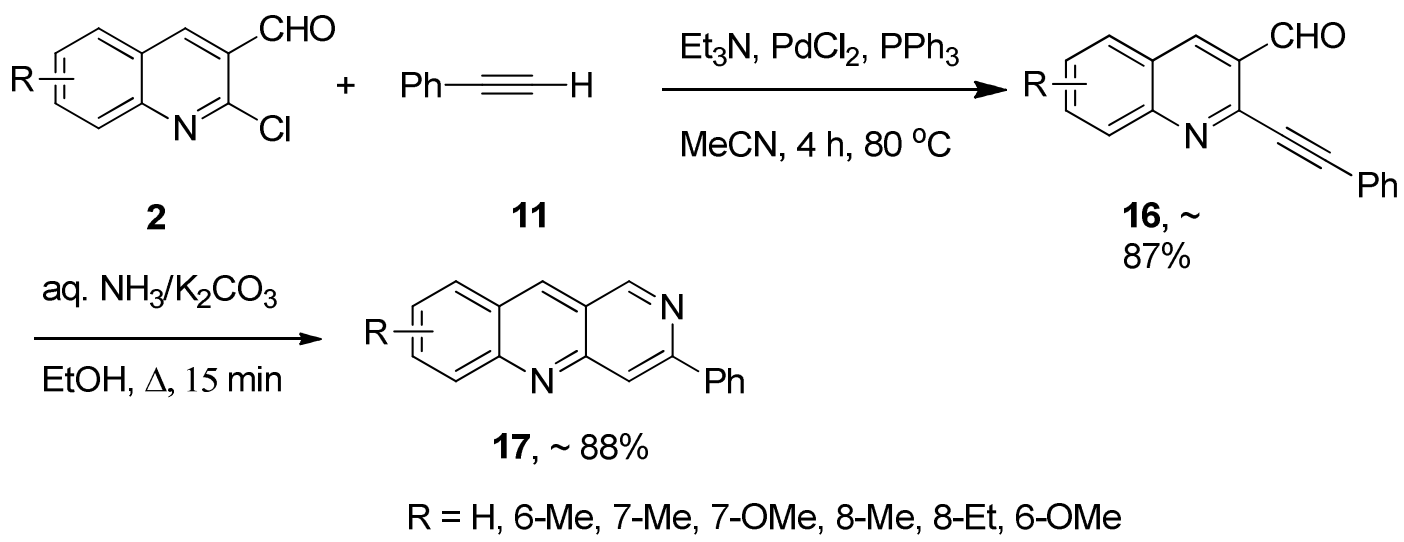

\section{Scheme 7}

Reaction of one equivalent of $S$-(-)-BINOL with 2.1 equivalent of aldehyde 2 in DMF in the presence of $\mathrm{K}_{2} \mathrm{CO}_{3}$ gave the dialdehyde 18, which was reduced to diol 19 using $\mathrm{NaBH}_{4}$ in methanol, followed by reaction with phosphorus tribromide $\left(\mathrm{PBr}_{3}\right)$ to give the dibromide 20 in $71 \%$ yield. Reaction of the dibromide 21 with 2.1 equivalent of benzimidazole in acetonitrile in the presence of aqueous $\mathrm{NaOH}$ for 2 days afforded the precyclophane 21 in $69 \%$ yields. Coupling of the precyclophane with one equivalent of 2,6-bis(bromomethyl)pyridine under reflux and under high dilution conditions for 5 days gave the quinolinophane 22 in $67 \%$ yield (Scheme 8). ${ }^{32}$ 


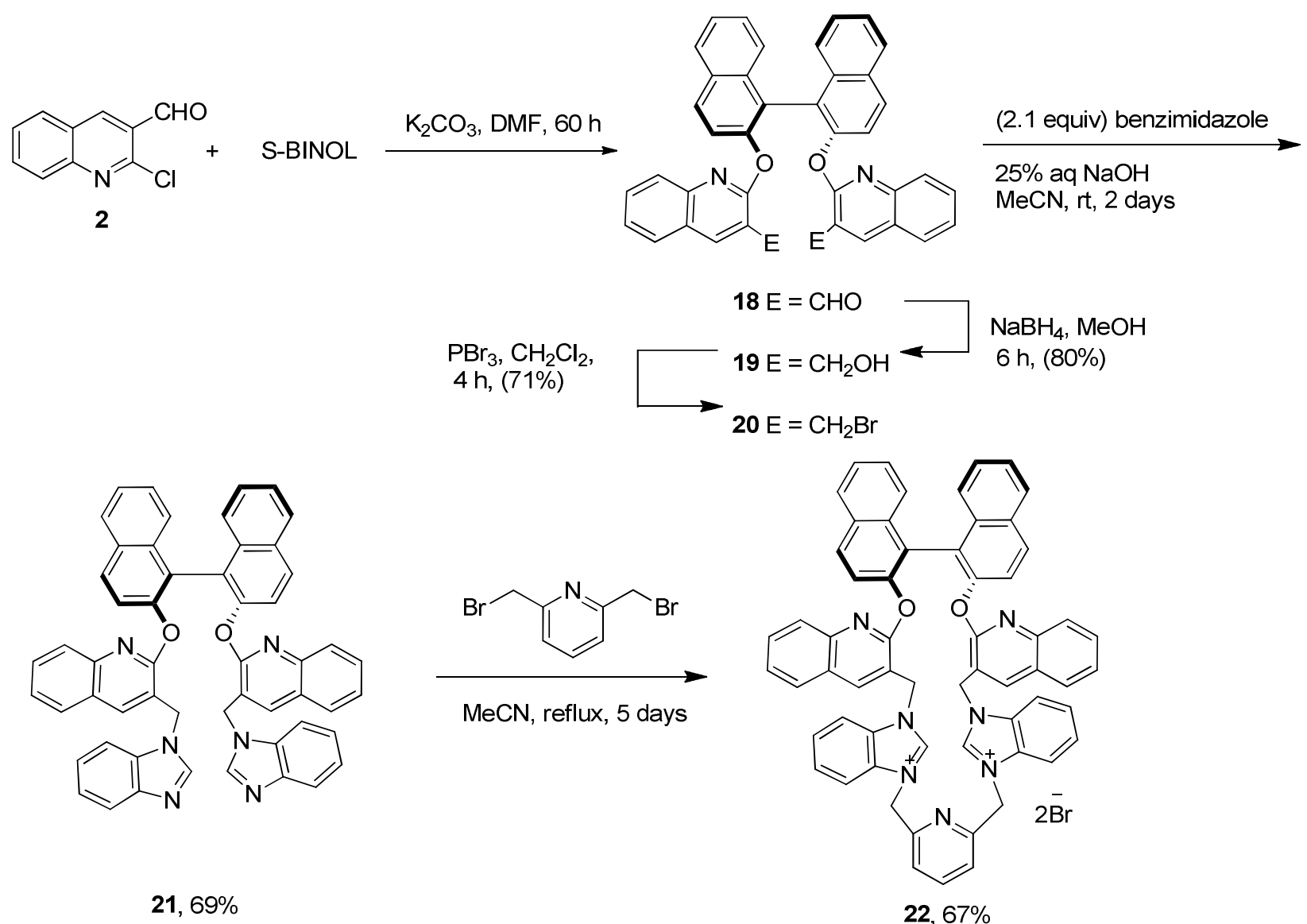

\section{Scheme 8}

3-(Quinolin-3-ylmethyl)quinazolin-4(3H)-one 27 (79\%) was synthesized via reaction of 3(bromomethyl)quinoline 25 with quinazolin-4(3H)-one 26 in DMF in the presence of $\mathrm{NaH}$ under ultrasound irradiation. 3-(Bromomethyl)quinoline 25 (77\%) was prepared by reduction of aldehyde 23, which resulted from reaction of aldehyde 2 with $p$-cresol in DMF in the presence of $\mathrm{K}_{2} \mathrm{CO}_{3}$, in methanol in the presence of $\mathrm{NaBH}_{4}$ followed by treated with $\mathrm{PBr}_{3}$ in dichloromethane under ice cold condition (Scheme 9). The synthesized compound was screened in vitro for antimicrobial activity. ${ }^{33}$ 

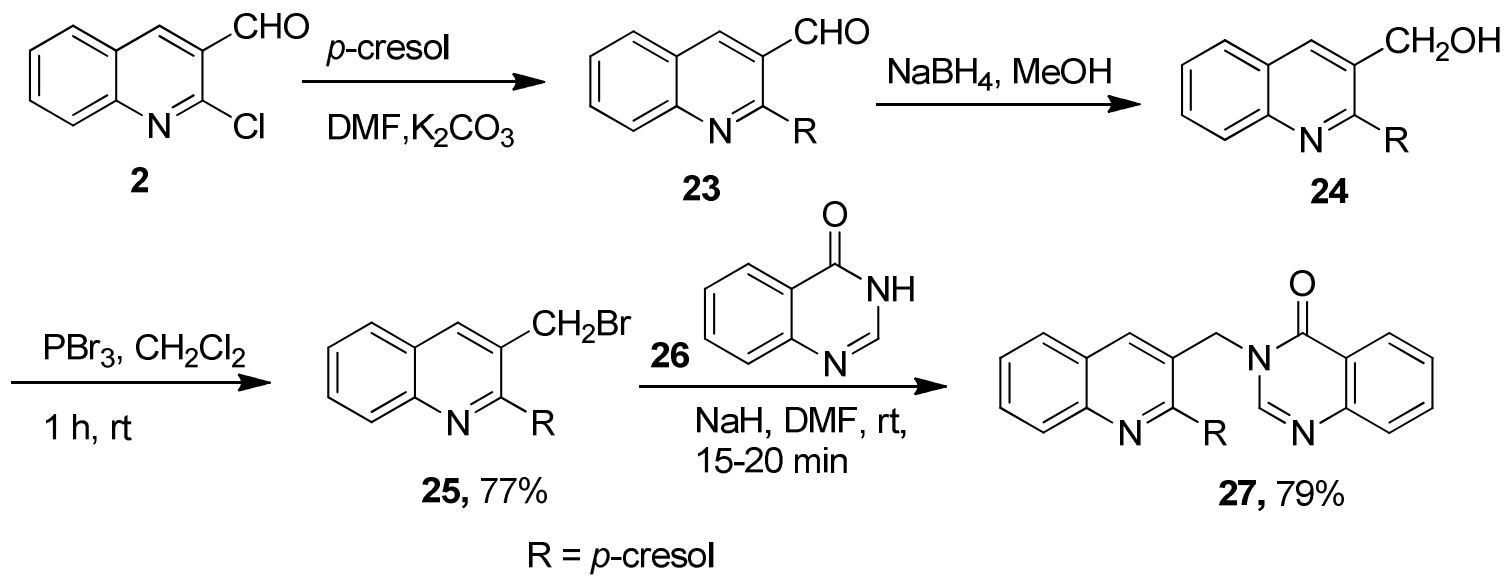

\section{Scheme 9}

The reaction of aldehyde 2 with ethanol in the presence of $\mathrm{KOH}$, afforded 2-ethoxy-3formylquinoline 28 which was reduced with $\mathrm{NaBH}_{4}$ in methanol to give the alcohol which on further reaction with $\mathrm{PPh}_{3}$ and $\mathrm{I}_{2}$ in the presence of imidazole in dry $\mathrm{CH}_{2} \mathrm{Cl}_{2}$ gave 2-ethoxy-3(iodomethyl)quinoline 29 in good yield. The later compound when reacted with sodium azide in DMF at $60{ }^{\circ} \mathrm{C}$ 3-(azidomethyl)-2-ethoxyquinoline $\mathbf{3 0}$ was obtained. Quinoline azide $\mathbf{3 0}$ was reacted with bis(propargyloxy)-(S)(-)-BINOL 31 in the presence of $\mathrm{CuSO}_{4} .5 \mathrm{H}_{2} \mathrm{O}$ and sodium ascorbate in a mixture of water and THF (1:3) at room temperature to give the bis-triazole chiral dendrimer 32 in excellent yield (Scheme 10). ${ }^{34}$

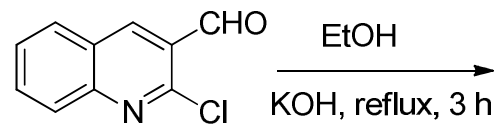

2<smiles>CCOc1nc2ccccc2cc1C=O</smiles>

28, $85 \%$

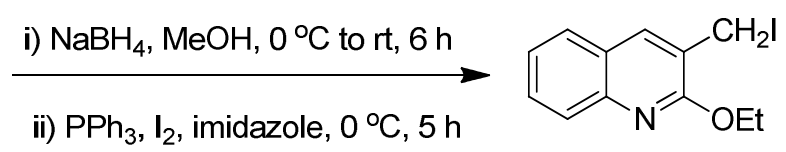

$29,72 \%$

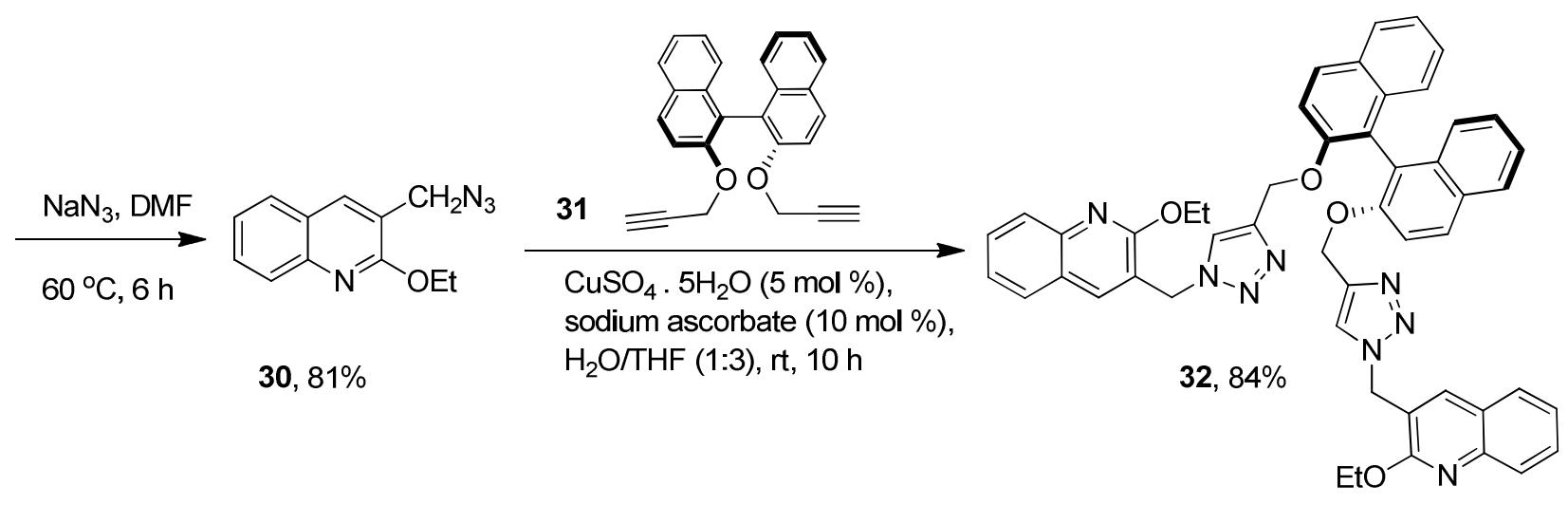

\section{Scheme 10}


Aldehyde 2 was treated with allyl alcohol in the presence of sodium hydroxide under phase transfer catalytic conditions to give allyl ether 33. Oxime 34 was prepared from reaction of allyl ether with hydroxylamine hydrochloride in the presence of aqueous sodium hydroxide. Compound 34 on treatment with $\mathrm{NaOCl}$ in the presence of $\mathrm{Et}_{3} \mathrm{~N}$ at $0-20{ }^{\circ} \mathrm{C}$ afforded dihydro- $3 \mathrm{H}$ $[1,2]$ oxazolo[3', 4':4,5]pyrano[2,3- $b$ ]quinoline $\mathbf{3 6}$ in excellent yields via 1,3-dipolar cycloaddition of the nitrile oxides (Scheme 11). ${ }^{35}$<smiles></smiles>

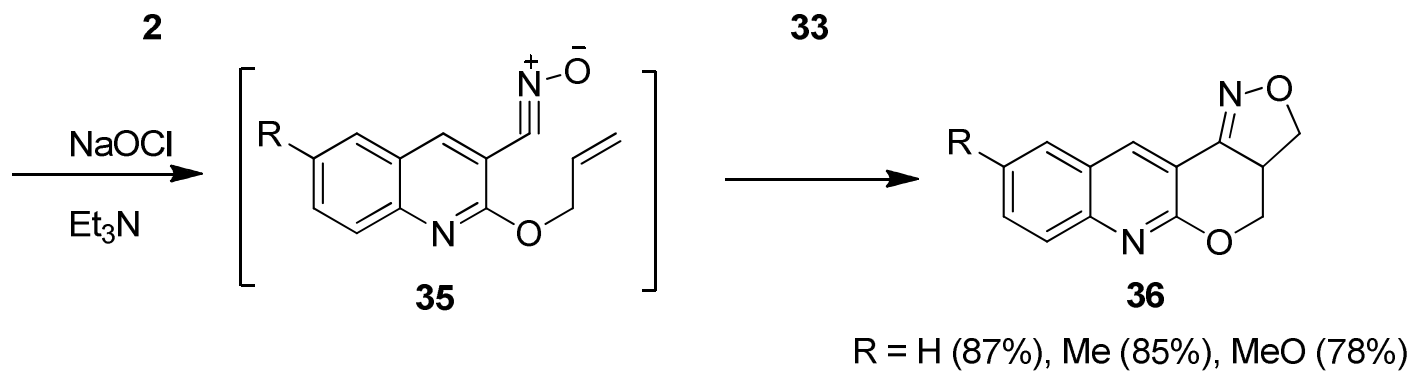

\section{Scheme 11}

3-Formyl-2-mercaptoquinolines 37 were synthesized in good yields by one-pot reaction of aldehyde 2 with sodium sulfide and hydrochloric acid in hot ethanol. ${ }^{36-38}$ Isothiazolo[5,4- $b$ ]quinolines 38 were obtained by reaction between $\mathbf{3 7}$ and hydroxylamine followed by cyclization with $\mathrm{Ac}_{2} \mathrm{O}$. Subsequently, compound 38 was oxidized with $\mathrm{H}_{2} \mathrm{O}_{2}$ in acetic acid to give $2 \mathrm{H}$ isothiazolo[5,4-b]quinoline 1,1-dioxides 39 (Scheme 12). ${ }^{38}$

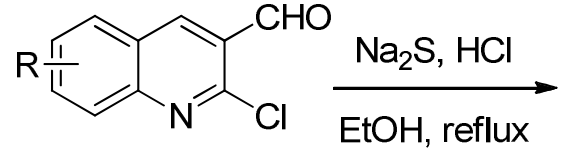

2<smiles>[R]c1ccc2cc(C=O)c(=S)[nH]c2c1</smiles>

$37,76-88 \%$

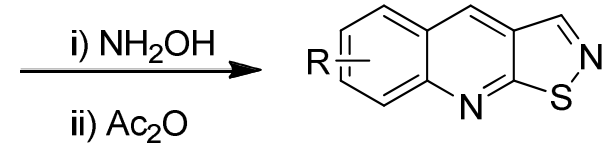

38

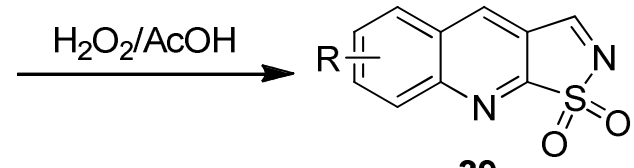

39

$\mathrm{R}=\mathrm{H}, 6-\mathrm{Me}$, 7-Me, 8-Me, 6-OMe, 7-OMe, 8-OMe, 6-Cl, 7-Cl, 6- $\mathrm{Br}$, $6,7-\mathrm{OMe}, 5,6,7-\mathrm{OMe}$

\section{Scheme 12}


2-hydroselenoquinoline-3-carbaldehydes $\mathbf{4 0}$ were synthesized in a quantitative yield by reaction of aldehydes 2 with sodium hydrogen selenide in ethanol. 2-hydroselenoquinoline-3carbaldehydes $\mathbf{4 0}$ were reacted with aniline in glacial acetic acid to give 3[(phenylimino)methyl]quinoline-2-selenol 41. Subsequently, the later compound was refluxed with a stoichiometric and nonstoichiometric amount of chloroacetyl chloride in DMF to afford the corresponding 3-[[(phenylimino)methyl]quinolin-2-yl] chloroethaneselenates 42 and [3-(3chloro-4-oxo-1-phenylazetidin-2-yl)quinolin-2-yl] chloroethaneselenates $\mathbf{4 3}$, respectively (Scheme 13). ${ }^{39}$

Selenopheno[2,3- $b$ ]quinoline-2-carboxamide 44 and phenyl(selenopheno[2,3- $b$ ]quinolin-2yl)methanone 45 were prepared in good yields by treating 2-(hydroseleno)quinoline-3carbaldehyde with 2-chloroacetamide and phenacyl bromide, respectively under solvent free microwave irradiation in one pot reaction (Scheme 14). ${ }^{40}$<smiles>[R]c1cc2cc(C=O)c(Cl)nc2cc1[R]</smiles>

2 i) $\mathrm{NaBH}_{4}, \mathrm{Se}, \mathrm{H}_{2} \mathrm{O}$

ii) $\mathrm{EtOH}$, reflux<smiles>[R]c1cc2cc(C=O)c(S)nc2cc1[R]</smiles>

40, $70-80 \%$

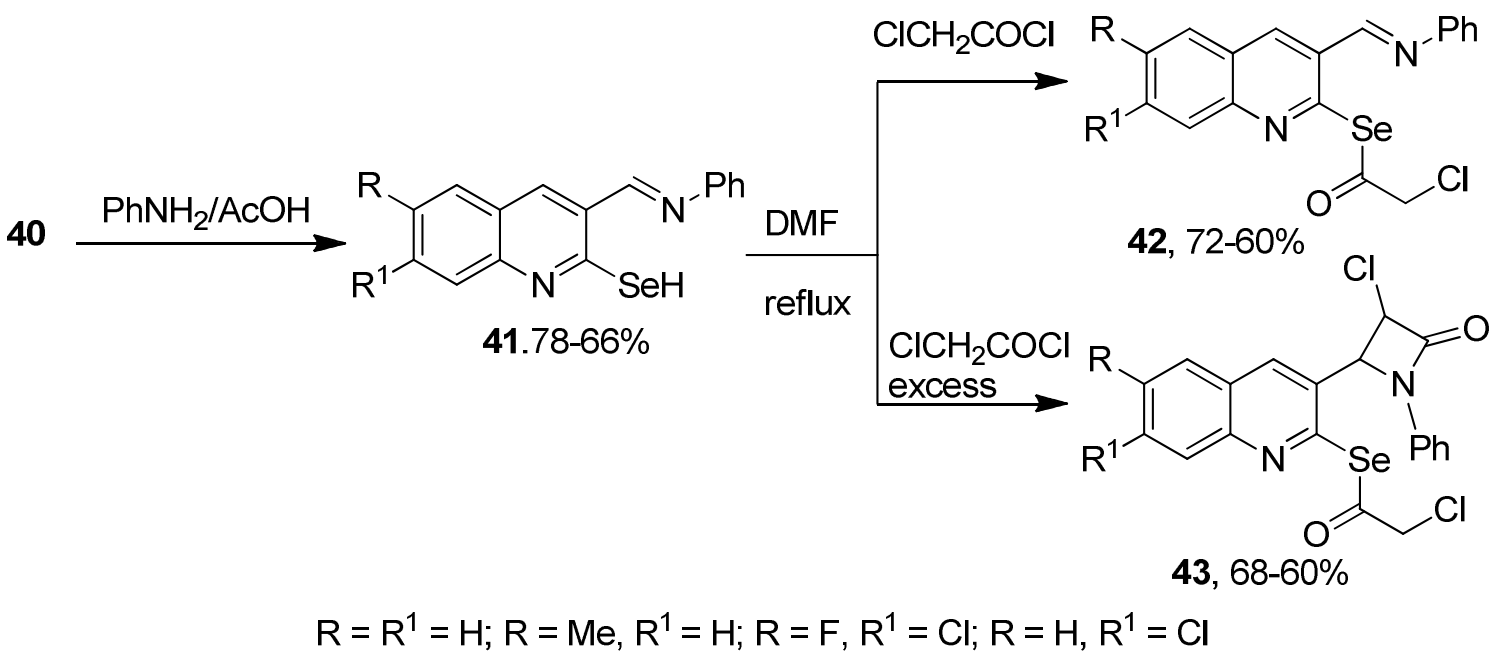

\section{Scheme 13}




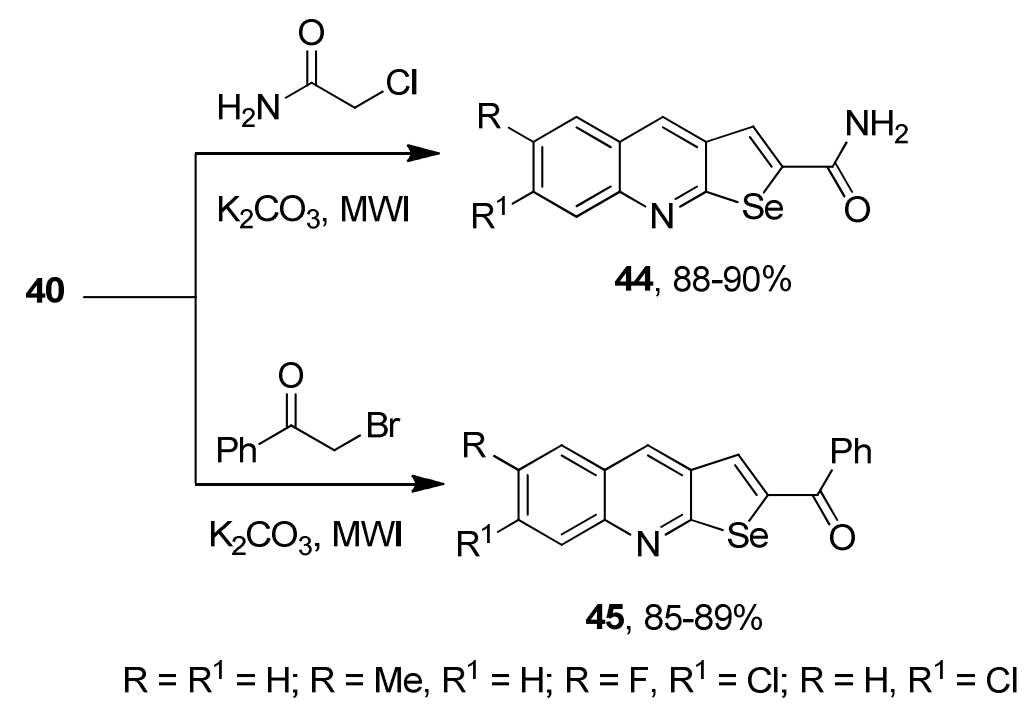

\section{Scheme 14}

2-(Naphthalen-2-ylthio)quinoline-3-carbaldehyde 47 was prepared from reaction between aldehyde 2 and naphthalene-2-thiol 46 in $\mathrm{K}_{2} \mathrm{CO}_{3} / \mathrm{DMF}$ (Scheme 15). ${ }^{41}$

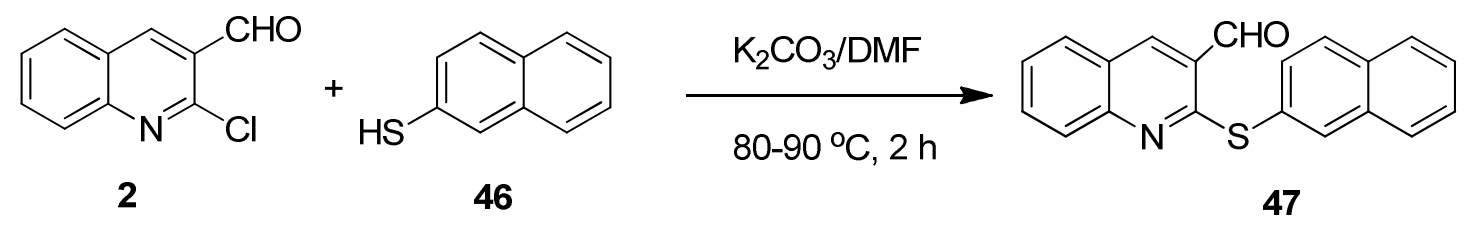

\section{Scheme 15}

2-(5-Aryl-4H-1,2,4-triazol-3-ylthio)quinoline-3-carbaldehydes $\mathbf{4 9}$ were prepared by reaction of aldehyde 2 with 5-aryl-4H-1,2,4-triazole-3-thiol 48 in refluxing ethanol in the presence of pyridine. The later compound on reaction with substituted acetophenone gave 1-aryl-2-(2-aryl$9 H-[1,2,4]$ triazolo[3,2-b][1,3]thiazino[6,5-b]quinolin-9-yl)ethanones $\mathbf{5 0}$ (Scheme 16). ${ }^{42}$ 
<smiles>[R][R]1ccc2nc(Sc3nnc([R7])[nH]3)c(CO)cc2c1</smiles><smiles>[R]C(=O)CC1c2cc3c(nc2Sc2nc([R1])nn21)C=C[R]C=C3</smiles>

$$
\mathrm{R}=\mathrm{H}, 6-\mathrm{Me}, 8-\mathrm{Me} ; \mathrm{R}^{1}=\mathrm{Ph}, 4-\mathrm{OHC}_{6} \mathrm{H}_{4} ; \mathrm{R}^{2}=\mathrm{Ph}, 4-\mathrm{CIC}_{6} \mathrm{H}_{4}
$$

\section{Scheme 16}

It has been reported that the amination of aldehyde $\mathbf{2}$ occurs either by microwave-enhanced reaction using ammonium acetate as constituent synthons using tetrabutyl ammonium bromide (TBAB) as a catalyst. $^{43}$ or by using dry ammonia gas in ethanol, to obtain 2-amino-3quinolinecarbaldehyde 51, ${ }^{44}$ which was condensed with cyclopentanone in the presence of acetic and sulfuric acids to give 2,3-dihydro- $1 H$-benzo[ $g]$ cyclopenta $[b][1,8]$ naphthyridine 52 (Scheme $17){ }^{44}$

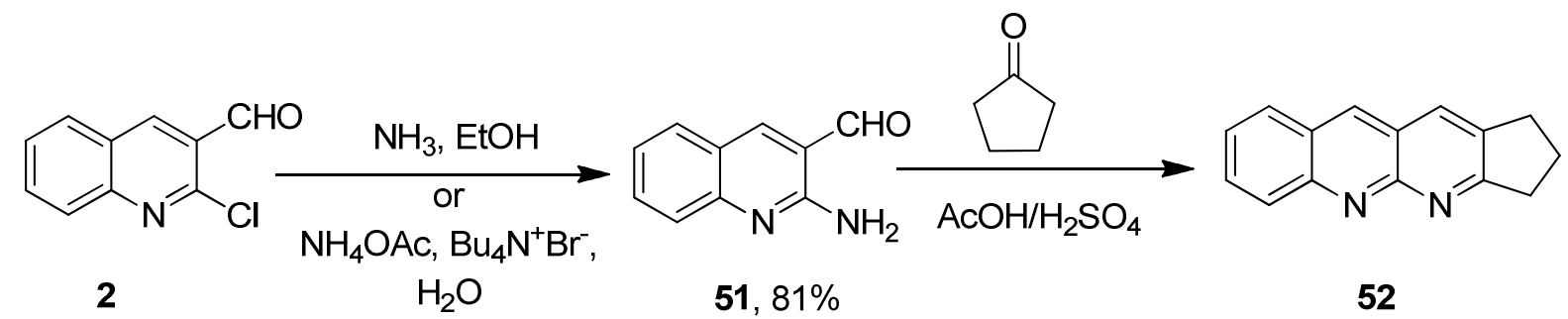

\section{Scheme 17}

Aldehyde 2 was converted into 2-oxoquinoline-3-carbaldehyde $\mathbf{5 3}$ when refluxed in $70 \%$ acetic acid, followed by reaction with substituted hydrazides, to afford the corresponding aroyl hydrazone 54 (Scheme 18). ${ }^{45}$ 
<smiles>O=Cc1cc2ccccc2nc1Cl</smiles>

2<smiles>O=Cc1cc2ccccc2[nH]c1=O</smiles>

$53,85 \%$<smiles>[R]C(=O)N/N=C/c1cc2ccccc2[nH]c1=O</smiles>

54

$$
\mathrm{R}=\mathrm{Ph}, 2-\mathrm{OHC}_{6} \mathrm{H}_{4}, 3,4-\text { dimethylpyrryl }
$$

\section{Scheme 18}

The synthesis of 2-azidoquinoline-3-carbaldehydes $\mathbf{5 5}$ from reaction of aldehydes $\mathbf{2}$ with sodium azide in DMSO or DMF is reported, and their ring-chain tautomerism discussed (Scheme 19). ${ }^{9,10,46-48}$<smiles>[R]c1cc2cc(C=O)c(Cl)nc2c([R])c1[R]</smiles>

$$
\mathrm{R}^{1}=\mathrm{H}, \mathrm{Me}, \mathrm{MeO} ; \mathrm{R}^{2}=\mathrm{H}, \mathrm{MeO} ; \mathrm{R}^{3}=\mathrm{H}, \mathrm{Me}
$$

\section{Scheme 19}

3-Formyl-2-(3-hydroxy-1,4-naphthoquinon-2-yl)-quinoline $\mathbf{5 7}$ was synthesized by reaction of aldehydes 2 with 2-hydroxy-1,4-naphthoquinone 56 in basic alumina using microwave irradiation (MWI) (Scheme 20). The synthesized compound showed promising antibacterial activity. ${ }^{49}$<smiles>O=Cc1cc2ccccc2nc1Cl</smiles>

2<smiles>O=C1C=C(O)C(=O)c2ccccc21</smiles>

56<smiles>O=Cc1cc2ccccc2nc1C1=C(O)C(=O)c2ccccc2C1=O</smiles>

57

\section{Scheme 20}




\subsection{Addition reactions at the aldehyde group}

2-Chloroquinoline-3-carbaldehyde $\mathbf{2}$ was reacted with ethyl lithiodiazoacetate $\mathbf{5 8}$ in THF to afford ethyl 3-(2-chloroquinolin-3-yl)-2-diazo-3-hydroxypropanoate $\mathbf{5 9}$ in $97 \%$ yields followed by mild oxidation with the Dess-Martin periodinane 60 to give ethyl 3-(2-chloroquinolin-3-yl)2-diazo-3-oxopropanoate (Scheme 21). ${ }^{50}$<smiles>O=Cc1cc2ccccc2nc1Cl</smiles>

2<smiles>CCOC(=O)C(Cl)=[W]</smiles>

58<smiles>CCOC(=O)C(=N)C(O)c1cc2ccccc2nc1Cl</smiles>

$59,97 \%$<smiles>CCOC(=O)C(=N)c1cc2ccccc2nc1Cl</smiles>

$60,92 \%$

\section{Scheme 21}

Epoxy ester 63 and $\beta$-hydroxy ester $\mathbf{6 2}$ were prepared in moderate yields from reaction of aldehyde $\mathbf{2}$ with ethyl 2-bromoacetate $\mathbf{6 1}$ according to Darzens condensation reaction (Scheme 22). ${ }^{51}$<smiles>CCOC(=O)COC1OC1c1cc2ccccc2nc1Cl</smiles>

a) $t$-BuOK, DMSO, $15-20^{\circ} \mathrm{C}, 1 \mathrm{~h}$; rt, $24 \mathrm{~h}$; pentane, aq. $\mathrm{NH}_{4} \mathrm{Cl}$

\section{Scheme 22}

Morita-Baylis-Hillman reaction of aldehyde $\mathbf{2}$ with methyl or ethyl acrylate and acrylonitrile 64 under ultrasonic irradiation to provide the corresponding MBH adducts 65 in good yield. The later adducts were reacted with tert-butyldimethylsilyl triflate (TBSOTf) or with acetyl chloride to give silylated $66,{ }^{52}$ or acetated $67,{ }^{53}$ Morita-Baylis-Hillman adducts, respectively in good yield (Scheme 23). 
<smiles>O=Cc1cc2ccccc2nc1Cl</smiles>

2

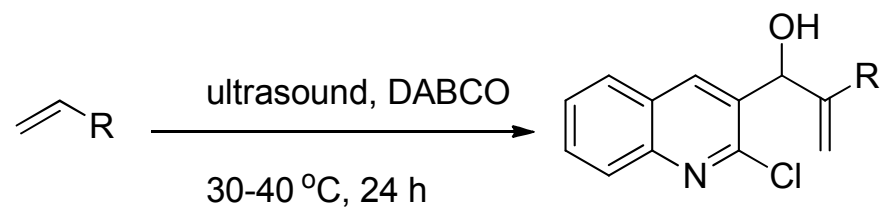

64
65

$$
\mathrm{R}(\%)=\mathrm{CN}(71 \%), \mathrm{CO}_{2} \mathrm{Me}(85 \%), \mathrm{CO}_{2} \mathrm{Et}(87 \%)
$$

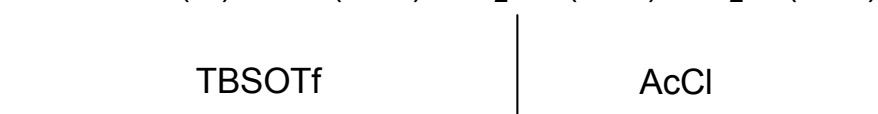

66

$$
\begin{aligned}
\mathrm{R}(\%) & =\mathrm{CN}(83 \%), \mathrm{CO}_{2} \mathrm{Me}(100 \%), \mathrm{CO}_{2} \mathrm{Et}(93 \%) \\
\mathrm{DABCO} & =1,4 \text {-diazabicyclo[2.2.2]octane }
\end{aligned}
$$

\section{Scheme 23}

Ethyl 2-[(2-chloroquinolin-3-yl)(hydroxy)methyl]acrylate $\mathbf{6 5}$ was treated with tris(dibenzylideneacetone)dipalladium $(0)\left[\mathrm{Pd}_{2}(\mathrm{dba})_{3}\right]$ and carbon monoxide to give quinolinephthalide 68 as major product and tetrasubstituted olefin 69 as minor product (Scheme 24). The phthalide $\mathbf{6 8}$ showed a potent effect on the proliferation of human tumor cell lines. ${ }^{54,55}$

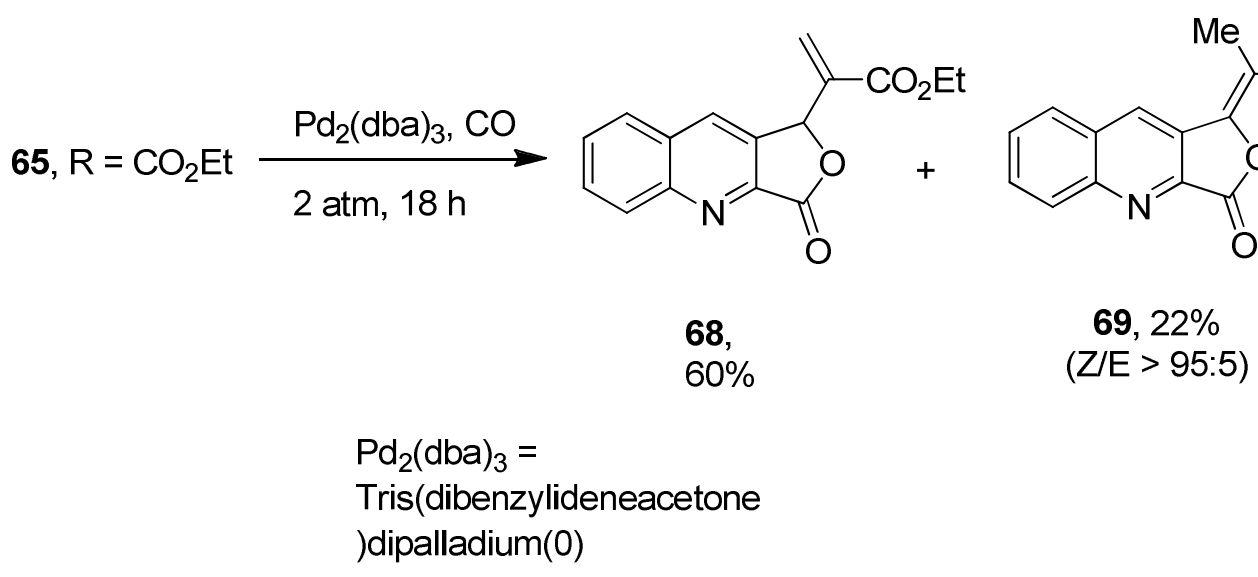

\section{Scheme 24}


The reaction of ethyl aminocrotonate $\mathbf{7 0 a}{ }^{21}$ or 3,3-diaminoacrylate $\mathbf{7 0 b} \mathbf{b}^{56}$ with aldehyde $\mathbf{2}$ in DMF at room temperature gave diethyl 4-(2-chloroquinolin-3-yl)-1,4-dihydropyridine-3,5dicarboxylate 71a,b and ethyl 2-amino-5-chlorobenzo[h][1,6]naphthyridine-3-carboxylate 72 via intermediates $\mathbf{A}$ and $\mathbf{B}$, respectively (Scheme 25).

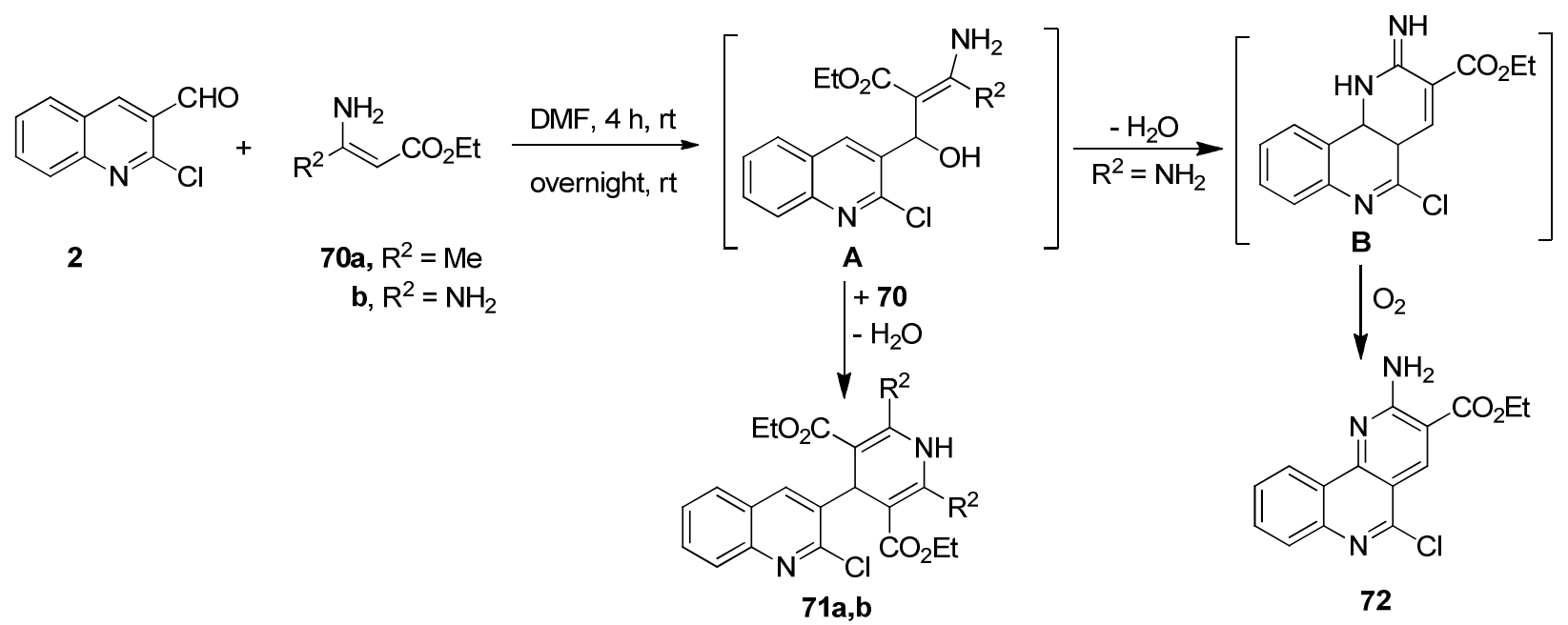

\section{Scheme 25}

The Wittig reaction of cholesteryl triphenylphosphonioacetate chloride 73a with aldehyde 2 in ethanol in the presence of $\mathrm{Et}_{3} \mathrm{~N}$ gave the cholesteryl 3-(2-chloroquinolin-3-yl)acrylate 74 (Scheme 26). ${ }^{57}$

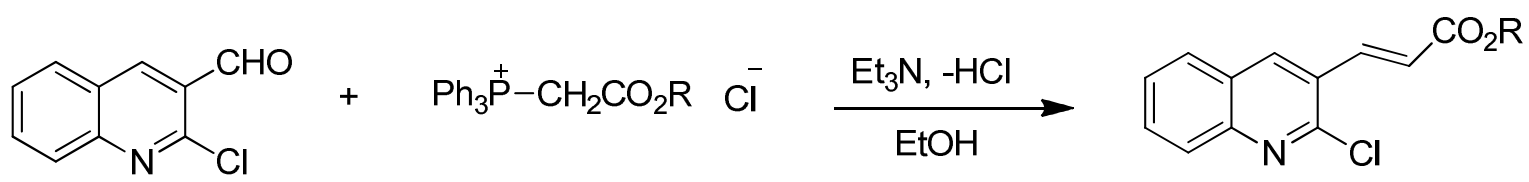

2
$73 a$

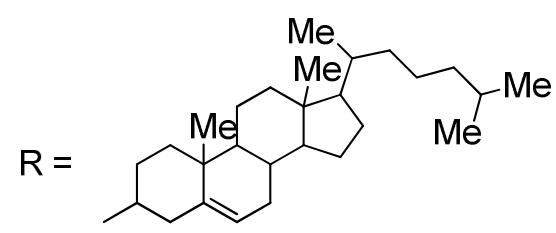

74, $75 \%$

\section{Scheme 26}

Condensation of aldehyde $\mathbf{2}$ with stabilized phosphonium ylides $\mathbf{7 3 b}, \mathbf{c}$ in refluxing 1,2dimethoxyethane (DME) gave the corresponding $(E)$-quinolyl $\alpha, \beta$-unsaturated esters 75 with high stereoselectivity in good yields. 1,3-Dipolar cycloaddition of azomethine ylides, generated in situ from sarcosine and paraformaldehyde, to $\alpha, \beta$-unsaturated esters $\mathbf{7 5}$, gave pyrrolidine 
derivatives 76A followed by oxidation to pyrrole 76B with activated $\mathrm{MnO}_{2}$ in refluxing $\mathrm{THF}$ (Scheme 27). ${ }^{58}$<smiles>[R]OC(=O)C=Cc1cc2c([R])c([R])c([R])c([R])c2nc1Cl</smiles><smiles>[R]OC(=O)C1CN(C)CC1c1cc2c([R])c([R])c([R10])c([R])c2nc1Cl</smiles>

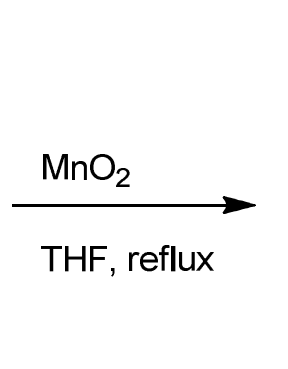<smiles>[R]OCc1cn(C)cc1-c1cc2c([R])c([R])c([R])c([R])c2nc1Cl</smiles>

(a) $\mathrm{R}^{1}=\mathrm{R}^{2}=\mathrm{R}^{3}=\mathrm{R}^{4}=\mathrm{H}$; (b) $\mathrm{R}^{1}=M e, \mathrm{R}^{2}=\mathrm{H}, \mathrm{R}^{3}=\mathrm{Me}, \mathrm{R}^{4}=\mathrm{H}$; (c) $\mathrm{R}^{1}=\mathrm{Me}, \mathrm{R}^{2}=\mathrm{R}^{3}=\mathrm{R}^{4}=\mathrm{H}$;

(d) $R^{1}=M e, R^{2}=H, R^{3}=M e, R^{4}=H ;$ (e) $R^{1}=M e, R^{2}=R^{3}=H, R^{4}=M e ;$ (f) $R^{1}=R^{2}=H$, $\mathrm{R}^{3}=\mathrm{OMe}, \mathrm{R}^{4}=\mathrm{H} ;(\mathrm{g}) \mathrm{R}^{1}=\mathrm{R}^{2}=\mathrm{H}, \mathrm{R}^{3}=\mathrm{Me}, \mathrm{R}^{4}=\mathrm{H} ;(\mathrm{h}) \mathrm{R}^{1}=\mathrm{H}, \mathrm{R}^{2}, \mathrm{R}^{3}=\mathrm{OCH}_{2} \mathrm{O}, \mathrm{R}^{4}=\mathrm{H}$

\section{Scheme 27}

The Abramov reaction between aldehyde $\mathbf{2}$ and triethyl phosphite, to synthesize $\alpha$ hydroxyphosphonate $\mathbf{7 7}$, was performed either by traditional or ultrasound irradiation using several catalyst such as chlorotrimethylsilane at room temperature ${ }^{59}$ (yield: $96 \%$ ) as well as at reflux temperature (yield 77-83\%), ${ }^{2}$ ammonium metavanadate $\left(\mathrm{NH}_{4} \mathrm{VO}_{3}\right)$ at room temperature (yield 94\%), ${ }^{60}$ potassium dihydrogen phosphate $\left(\mathrm{KH}_{2} \mathrm{PO}_{4}\right)$ (yield $\left.90 \%\right),{ }^{61}$ or sulfamic acid $\left(\mathrm{NH}_{2} \mathrm{SO}_{3} \mathrm{H}\right)$ under ultrasound irradiation (yield 88\%). ${ }^{62}$ Treatment $\alpha$-hydroxyphosphonate 77 with acetic anhydride in the presence of DBU catalyst afford $\alpha$-acetyloxyphosphonates 78 (yield 95\%) (Scheme 28). $\alpha$-Hydroxy 77 as well as $\alpha$-acetyloxyphosphonate $\mathbf{7 8}$ were screened for antibacterial.

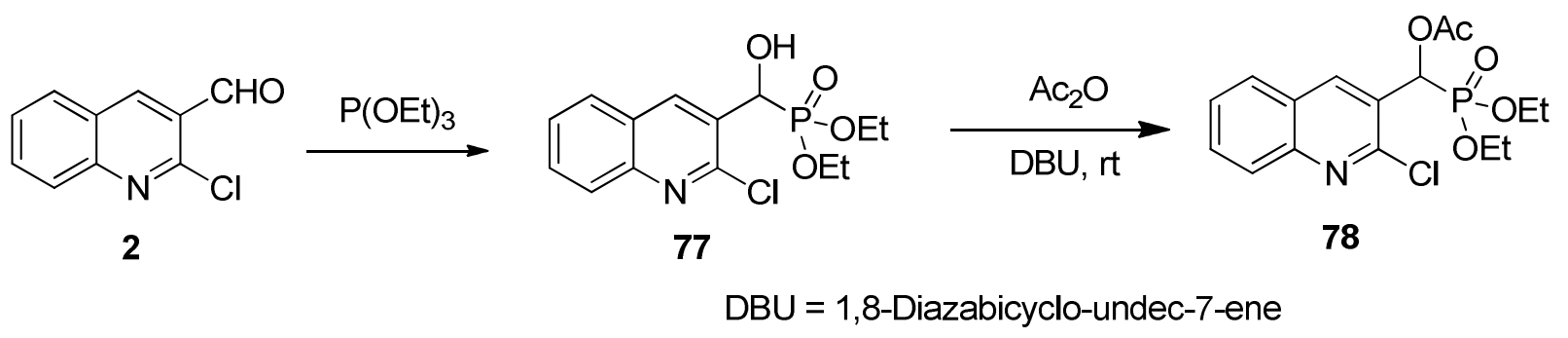

\section{Scheme 28}


The formation of tetrazoloquinoline-3-ylmethyl $\alpha$-alkoxy- 79 and $\alpha$-hydroxy-phosphonates 80 from reaction of 2-azidoquinoline-3-carbaldehydes 55 with trialkyl phosphites and dialkyl hydrogenphosphonates, respectively was recently reported (Scheme 29). The anti-inflammatory activity of the prepared compounds were determined in vivo by their effect on the acute carrageenin-induced paw edema in rats. ${ }^{9}$

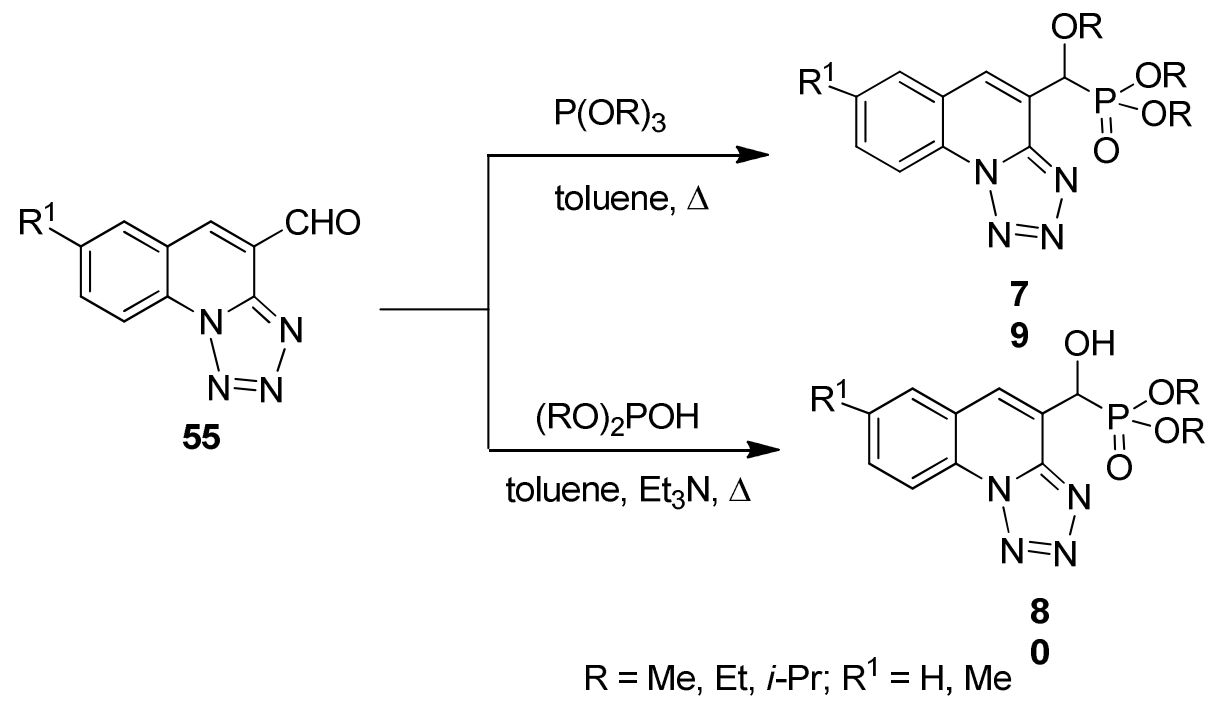

\section{Scheme 29}

A three-component reaction of aldehyde 2, amine, and triethyl phosphite was carried out under solvent-free conditions in the presence of either alum $\left[\mathrm{KAl}\left(\mathrm{SO}_{4}\right)_{2} \cdot 12 \mathrm{H}_{2} \mathrm{O}\right]{ }^{63}$ or yttriazirconia as a catalyst ${ }^{64}$ to afford the corresponding $\alpha$-aminophosphonate $\mathbf{8 1}$ in $94 \%$ or $75 \%$, respectively (Scheme 30).<smiles>O=Cc1cc2ccccc2nc1Cl</smiles>

2

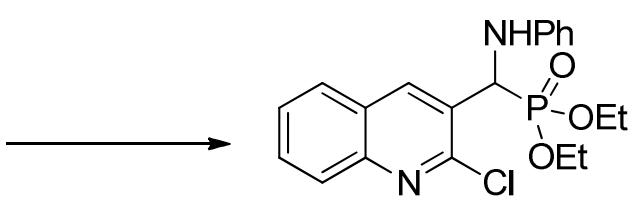

81, $94 \%$

\section{Scheme 30}

Synthesis of 3-[bis(2-phenyl-1H-indol-3-yl)methyl]-2-chloroquinoline $\mathbf{8 3}$ by a sequential approach involving gold (I) chloride catalyzed cycloisomerization/bis-addition and conjugate addition of 2-(phenylethynyl)aniline 82 to aldehyde 2 has been reported (Scheme 31). ${ }^{65,66}$ 


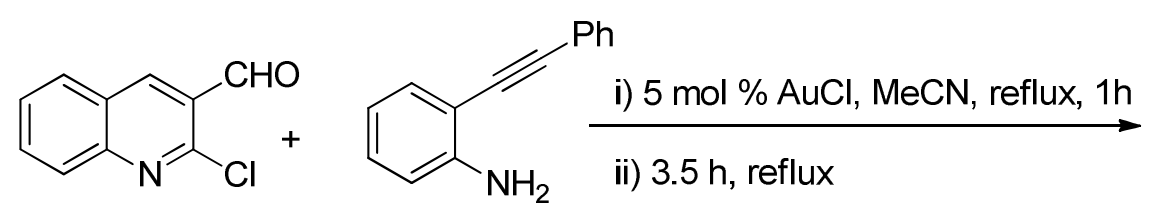

2

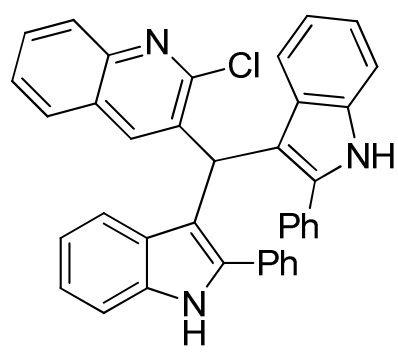

$83,59 \%$

\section{Scheme 31}

Allylation of 2-oxoquinoline-3-carbaldehyde $\mathbf{5 3}$ to give 3-homoallyl-2-quinolones 84 in excellent yields (89-94\%) was achieved by reaction with in situ generated allylindium bromide in aqueous DMF at room temperature. Intramolecular electrophilic cyclization of 84 with $\mathrm{I}_{2}$ in THF in the presence of sodium bicarbonate at room temperature gave $88 \%$ yield of a mixture of 4-hydroxy-2-iodomethylpyrano[2,3-b]quinolines 85/86, exclusively, or predominantly, racemic cis-diastereoisomers 85 (Scheme 32). ${ }^{67}$<smiles>[R][R1]1C=Cc2nc(Cl)c(C=O)cc2C=C1C(=O)O</smiles>
2

53

84<smiles>CCOc1ccc([18O]C(C)C)cc1</smiles>

\section{Scheme 32}

The reaction of aldehydes $\mathbf{2}$ with allyl bromide in the presence of indium powder yielded 2chloro-3-(1-hydroxybut-3-en-1-yl)quinolines $\mathbf{8 8}$ in good yield, followed by $\mathrm{Pd}(0)$-catalyzed intramolecular cyclization to afford 3-methylene-2,3-dihydro-1H-cyclopenta[b]quinolin-1-ols 89 (Scheme 33). ${ }^{68}$ 


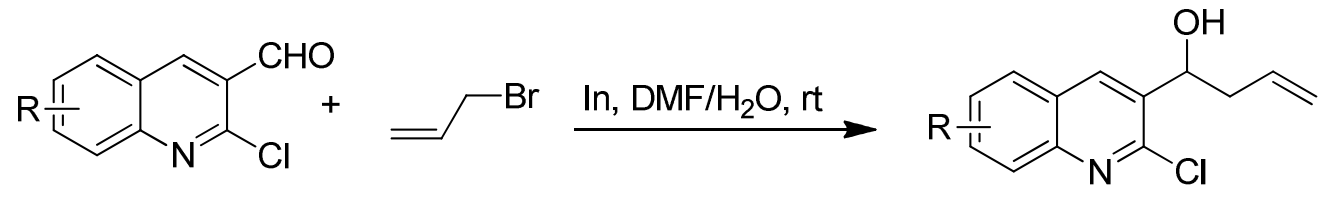

2

87

88, $82-92 \%$

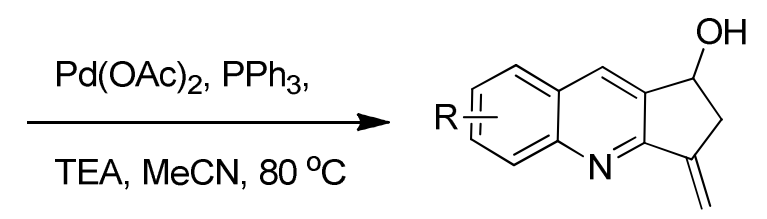

$89,53-36 \%$

$$
\mathrm{R}=\mathrm{H}, 7-\mathrm{Me}, 7-\mathrm{OMe}, 6-\mathrm{Me}, 8-\mathrm{Me}, 8-\mathrm{Et}
$$

\section{Scheme 33}

\subsection{Reduction of the aldehyde group}

2-Chloroquinoline-3-carbaldehydes 2 were reduced with sodium borohydride $\mathrm{NaBH}_{4}$ to (2chloroquinolin-3-yl)methanol 92 either by using microwave irradiation, ${ }^{69-72}$ or at room temperature. $^{73-76}$ Subsequently, compound 92 was converted into iodomethyl quinoline 93 through $\mathrm{PPh}_{3}$ and imidazole with iodine. Further, azidomethylquinoline 94 was obtained by treating 93 with $\mathrm{NaN}_{3}$ in the presence of DMF. Azidomethylquinoline 94 was subjected to catalytic hydrogenation at room temperature using $10 \% \mathrm{Pd} / \mathrm{C}$ for $2 \mathrm{~h}$ to afford quinoline isothiocyanate 95, which was coupled with substituted amino acid in the presence of $\mathrm{N}$-methyl morpholine in dry $\mathrm{CH}_{2} \mathrm{Cl}_{2}$ to give quinolinepeptidylthiourea esters 96 (Scheme 34). ${ }^{75}$

2-Chloroquinolin-3-ylmethanols 92 were converted into $O, O$-diethyl $O$-(2-chloroquinolin-3yl)-methyl phosphorothioates 98 by treatment with $O, O$-diethyl phosphorochloridothioate 97 in acetone in the presence of sodium hydroxide (Scheme 35$){ }^{76}$

Synthesis of 4-[[5-(difluoromethyloxy)-1H-benzimidazol-2-ylthio]methyl]tetrazolo[1,5-a]quinolines 102 was reported from substituted aldehydes 55 via reduction to the corresponding alcohols 99, followed by conversion into chlorides 100 with thionyl chloride, and finally coupling with 5-(difluoromethyloxy)-1H-benzimidazole-2-thiol 101 (Scheme 36). The synthesized compounds were screened for the antibacterial activity against gram positive and gram negative bacteria. ${ }^{47}$ 


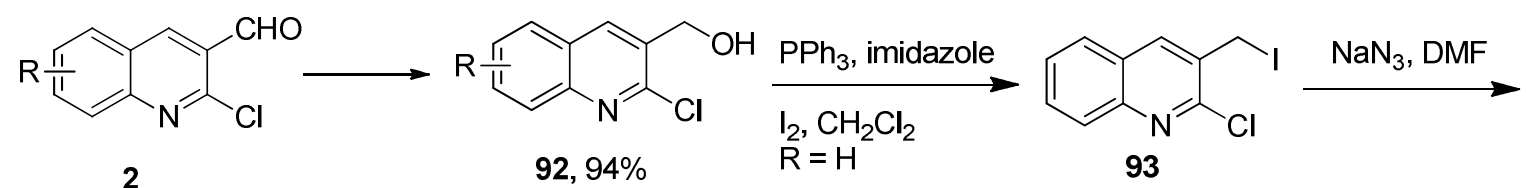

$\mathrm{R}=\mathrm{H}$, 8-Me, 7-Me, 8-OMe, 6-OMe<smiles>[R2]C([R2])C([R2])NC(=S)NCc1cc2ccccc2nc1Cl</smiles>

$94,78 \%$

$95,77 \%$

$96,85-78 \%$

$\mathrm{R}^{1}=\mathrm{H}, \mathrm{Me}, \mathrm{Ph}$, benzyl, isopropyl, isobutyl; $\mathrm{R}^{2}=\mathrm{Me}, \mathrm{Et}$

\section{Scheme 34}<smiles>[R]c1cc2cc(CO)c(Cl)nc2c([R])c1[R]</smiles>

2,92,98; $R^{1}=R^{2}=R^{3}=H(a) ; R^{1}=M e, R^{2}=R^{3}=H(b) ; R^{1}=R^{3}=H, R^{2}=M e(c) ; R^{1}=R^{2}=H, R^{3}=M e(d) ;$ $R^{1}=M e O, R^{2}=R^{3}=H(e) ; R^{1}=R^{3}=H, R^{2}=M e O(f) ; R^{1}=R^{2}=H, R^{3}=E t(g) ; R^{1}=E t O, R^{2}=R^{3}=H(h)$.

\section{Scheme 35}<smiles>[R]c1cc2cc(C=O)c3nnnn3c2c([R])c1[R]</smiles>

55<smiles>[R]c1cc2cc(CO)c3nnnn3c2c([R])c1[R]</smiles>

99<smiles>[R]c1cc2cc(CCCl)c3nnnn3c2c([R])c1[R]</smiles>

100<smiles>FC(F)Oc1ccc2[nH]c(S)nc2c1</smiles><smiles>[R]c1cc2cc(CSc3nc4cc(OC(F)F)ccc4[nH]3)c3nnnn3c2c([R])c1[R]</smiles>

102

$\mathrm{R}^{1}=\mathrm{H}, \mathrm{Me}, \mathrm{MeO} ; \mathrm{R}^{2}=\mathrm{H}, \mathrm{MeO} ; \mathrm{R}^{3}=\mathrm{H}, \mathrm{Me}$

\section{Scheme 36}




\subsection{Condensation Reactions}

3.4.1 Reactions with active methylene compounds. Perkin-type condensation of aldehyde 55 with tetraethyl methylenebisphosphonate 103 provided the corresponding tetrazoloquinolinebased bisphosphonate esters 104 (Scheme 37). ${ }^{9}$<smiles>[R]c1ccc2c(c1)cc(C=O)c1nnnn12</smiles>

55, $\mathrm{R}^{1}=\mathrm{H}, \mathrm{Me}$

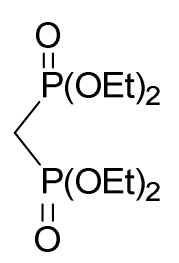

103<smiles>[R12]O[PH](=O)C(=Cc1cc2cc([R1])ccc2n2nnnc12)[P+](=O)OCC</smiles>

104

\section{Scheme 37}

(E)-Ethyl 3-(2-chloroquinolin-3-yl)acrylate 106 was synthesized by aldol and elimination reactions of aldehyde 2 with ethyl trifluoroacetoacetate $\mathbf{1 0 5}$ under basic conditions with high stereoselectivity (Scheme 38). ${ }^{77}$<smiles>O=Cc1cc2ccccc2nc1Cl</smiles>

2<smiles>CCOC(=O)CC(=O)C(F)(F)F</smiles>

105

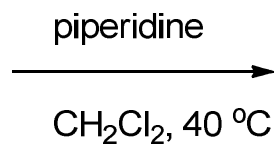

$\mathrm{CH}_{2} \mathrm{Cl}_{2}, 40^{\circ} \mathrm{C}$<smiles>CCOC(=O)/C=C/c1cc2ccccc2nc1Cl</smiles>

$106,85 \%$

\section{Scheme38}

Multi-component reaction of aldehyde 2, $p$-bromophenol 108, 2-benzothiazolethiol 107, and malononitrile was carried out under microwave irradiated in aq. $\mathrm{K}_{2} \mathrm{CO}_{3}$ to synthesize 2-amino-6(benzothiazol-2-ylthio)-4-(2-chloroquinolin-3-yl)-4H-chromene-3-carbonitrile 110 (Scheme 39). The synthesized compound was screened for their antibacterial activities against gram positive and gram negative pathogenic strains of bacteria. ${ }^{78}$ 

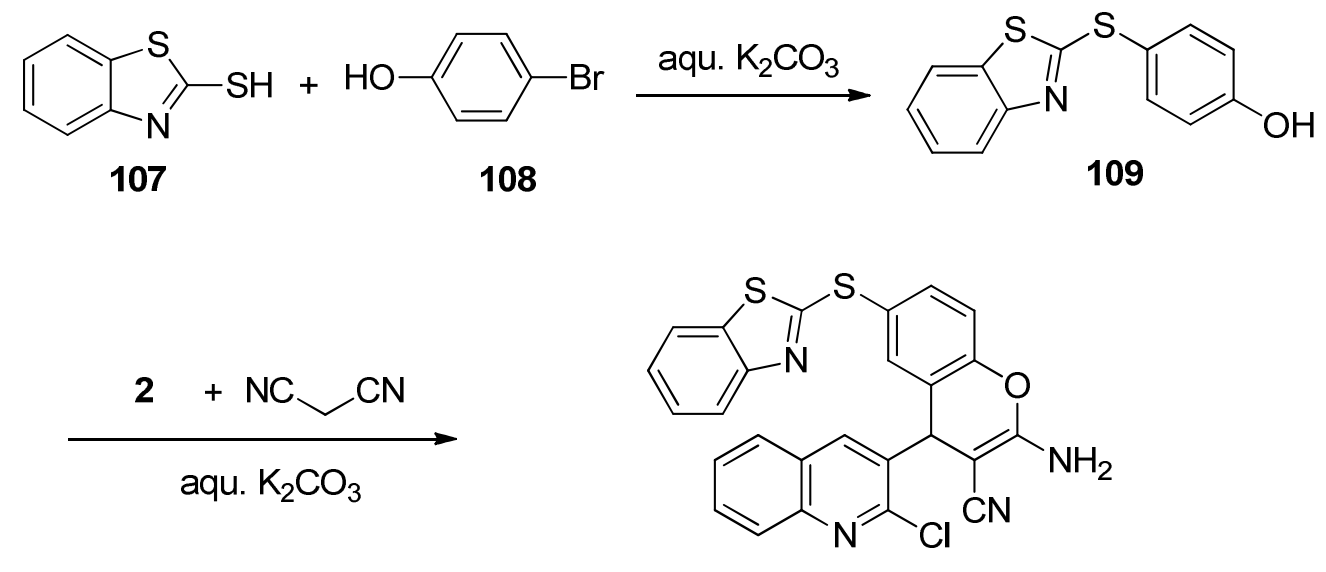

$110,64 \%$

\section{Scheme 39}

Claisen-Schmidt condensation of aldehydes 2 either with 3-(trifluoromethyl)-1H-pyrazol5(4H)-ones 111 in refluxing acetic acid or 5,7-dimethoxy-1-indanone 112 in methanolic sodium hydroxide at room temperature, afforded (E)-4-((2-chloroquinolin-3-yl)methylene)-3(trifluoromethyl)-1H-pyrazol-5(4H)-ones $\mathbf{1 1 3}^{79}$ and $(E)$-2-((2-chloroquinolin-3-yl)methylene)5,7-dimethoxy-2,3-dihydro-1H-inden-1-ones $\mathbf{1 1 4},{ }^{80}$ in good yields, respectively (Scheme 40). The latter compounds were evaluated in vitro for inhibition of $\beta$-hematin formation and hemoglobin hydrolysis and in vivo for efficacy against Plasmodium berghei suggest the antimalarial activity is derived from inhibition of hemoglobinolytic proteases. ${ }^{80}$

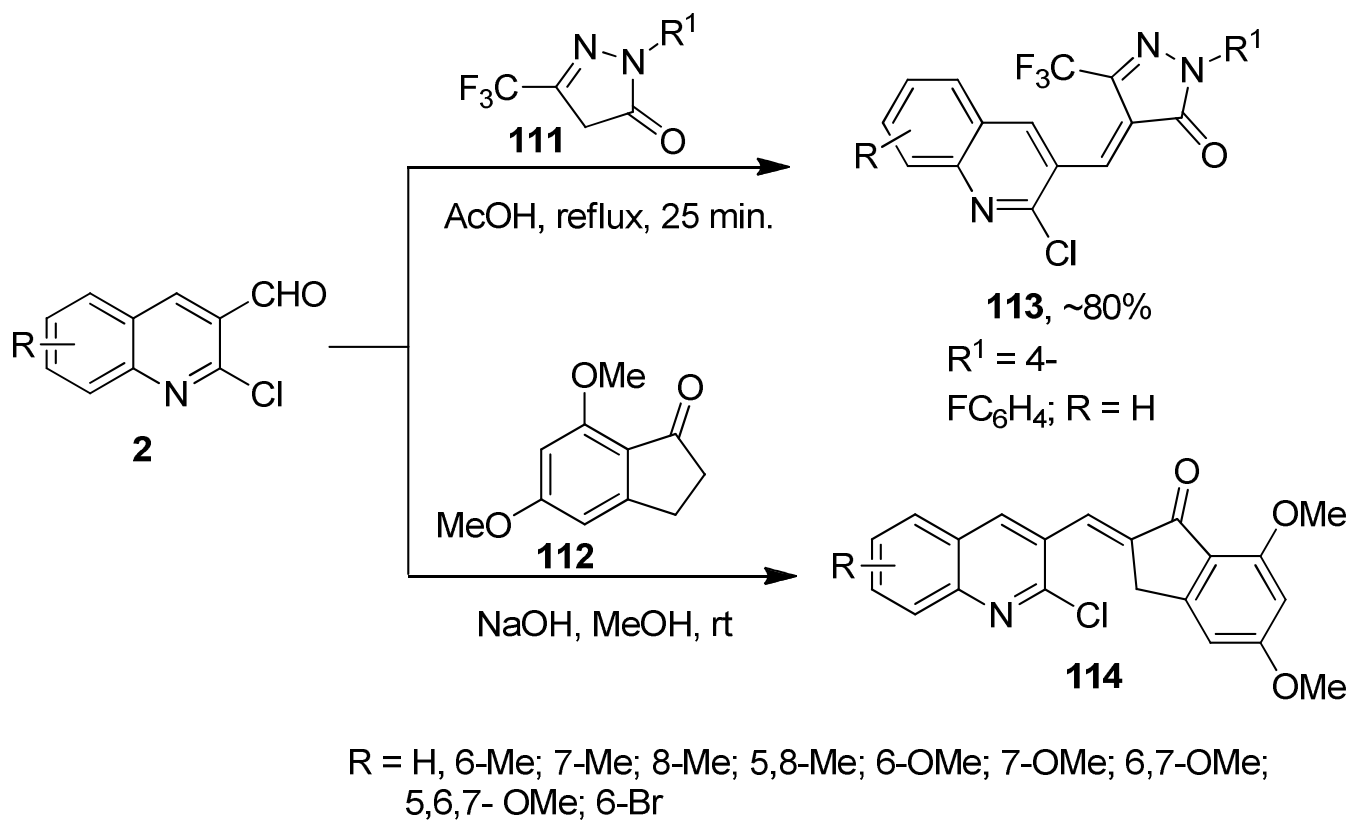

\section{Scheme 40}


Condensations of aldehydes $\mathbf{2}$ or $\mathbf{5 5}$ with aryl (heterocycles) methyl ketones either by using microwaves under solvent-free conditions or by using conventional methods, to give quinoline chalcones 116 was reported. ${ }^{10-18,81-88}$ Michael addition of tetraethyl methylenebisphosphonate to compounds $116\left(\mathrm{R}=\mathrm{Cl}, \mathrm{N}_{3}, \mathrm{R}^{1}=\mathrm{Ph}\right.$, thienyl, furyl, pyrryl) in EtOH/EtONa at refluxing temperature gave bisphosphonate adduct 117 (Scheme 41). ${ }^{10}$

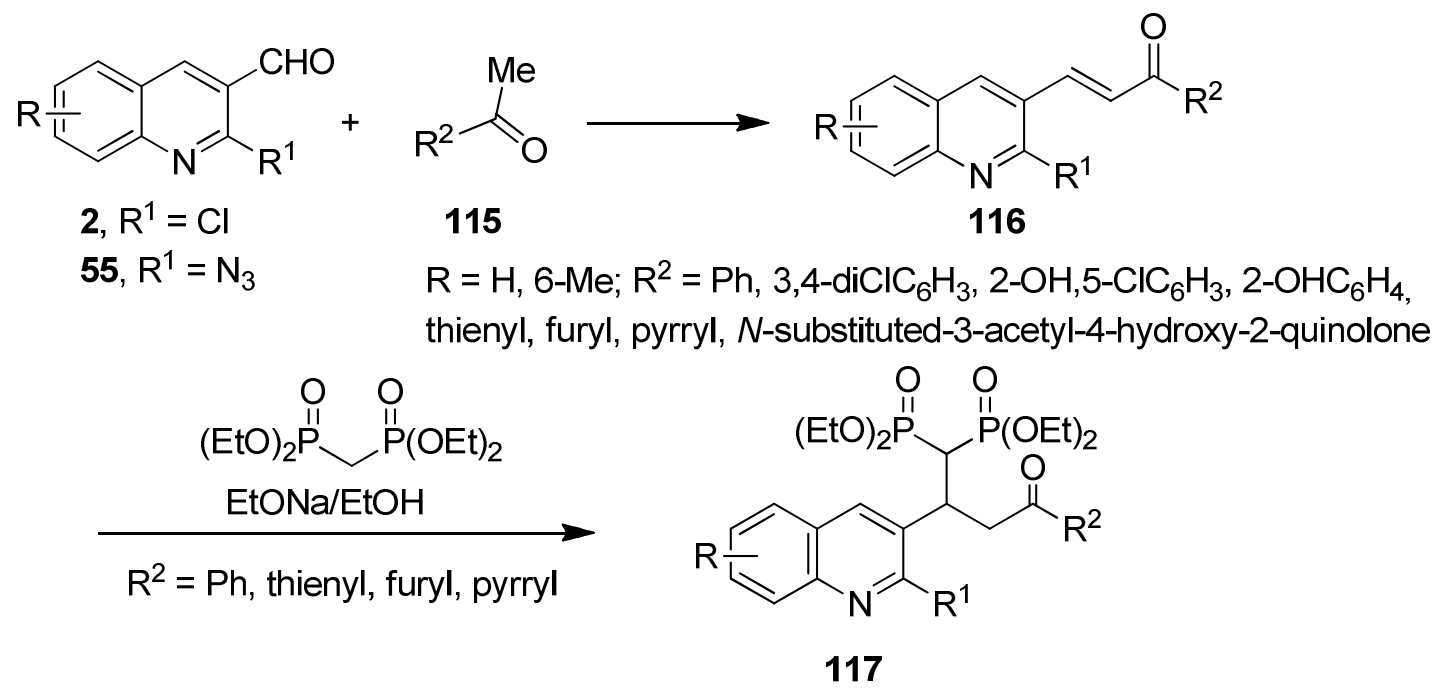

\section{Scheme 41}

Aldehydes 2 were treated with chromanones 118 in ethanol in the presence of sodium methoxide gave chalcones 119. The later compounds were reacted either with $o$-aminothiophenol in the presence of catalytic quantity of acetic acid to afford benzothiazepine system flanked by quinoline and chromanone moieties $\mathbf{1 2 0}$ or with ammonium acetate in acetic acid at reflux to give the amino chalcone 121 (Scheme 42$){ }^{22}$

6-Amino-4-(2-chloroquinolin-3-yl)-3-methyl-1-phenyl-1,4-dihydropyrano[2,3-c]pyrazole-5carbonitriles 124 were prepared by reaction between aldehyde 2 and 3-methyl-1-phenyl-1Hpyrazol-5(4H)-one 122 to afford 4-((2-chloroquinolin-3-yl)methylene)-3-methyl-1-phenyl-1Hpyrazol-5(4H)-ones 123 followed by cyclocondensation with malononitrile (Scheme 43). All the synthesized compounds have shown significant antimicrobial activity. ${ }^{89,90}$ 
<smiles>[R]c1ccc2nc(Cl)c(C=O)cc2c1</smiles>

2<smiles>[R]c1ccc2c(c1)C(=O)C[CH+]CO2</smiles>

118<smiles>[R]c1ccc2c(c1)C(=O)C(=Cc1cc3cc([R])ccc3nc1Cl)CO2</smiles>

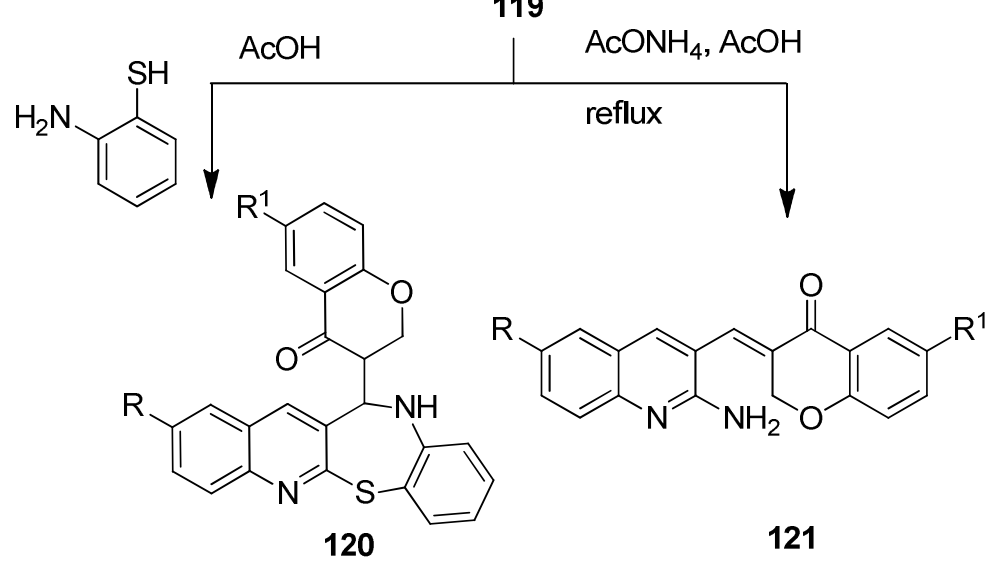

$\mathrm{R}=\mathrm{H}, \mathrm{Me}, \mathrm{OMe} ; \mathrm{R}^{1}=\mathrm{H}, \mathrm{Cl}, \mathrm{Me}, \mathrm{CH}(\mathrm{Me})_{2}, \mathrm{Et}$

\section{Scheme 42}

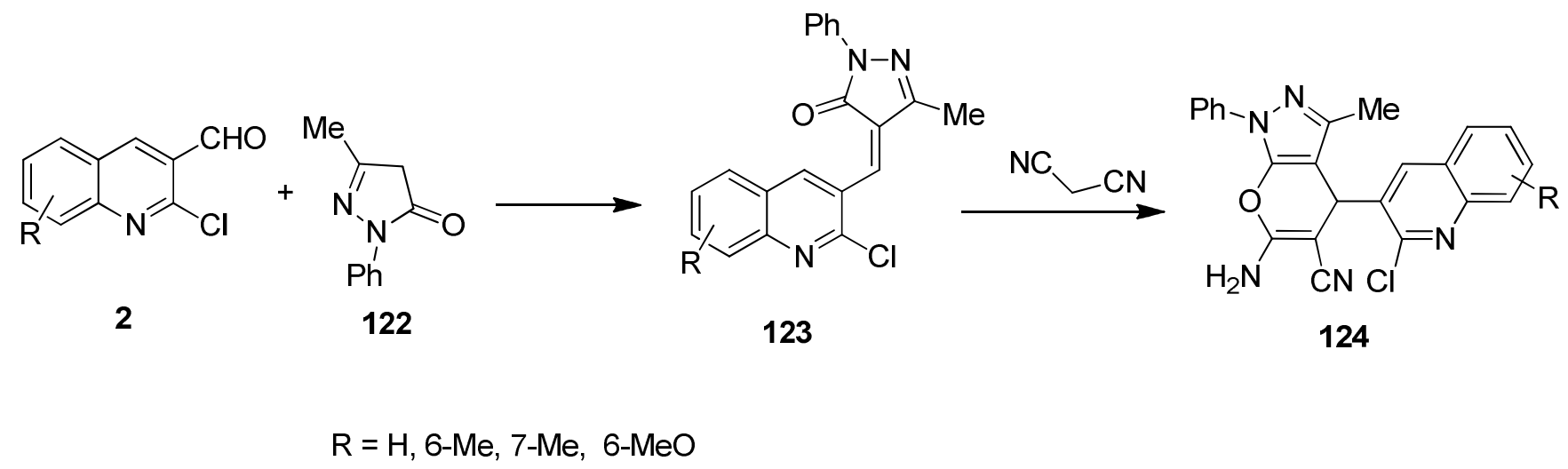

\section{Scheme 43}

Synthesis of 3-phenyl-2H-pyrano[2,3-b]quinolin-2-one 125 by the Perkin type reaction of aldehyde 2 with sodium 2-phenylacetate was reported (Scheme 44). ${ }^{91}$

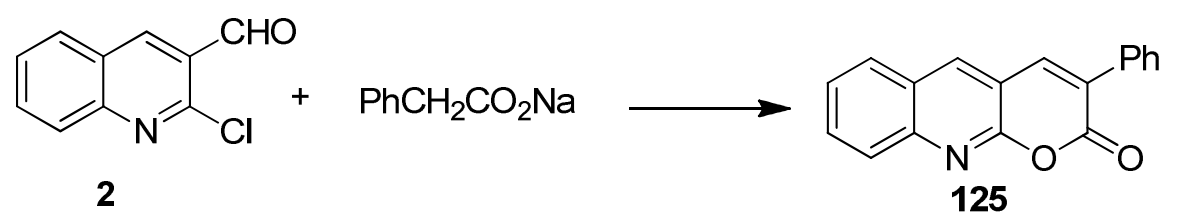

\section{Scheme 44}


Condensation of aldehyde $\mathbf{2}$ with nitroalkane $\mathbf{1 2 6}$ at room temperature in the presence of benzyltrimethylammonium hydroxide to give 2-chloro-3-(2-nitroalk-1-enyl)quinoline $\mathbf{1 2 7}$ in good yield (Scheme 45). ${ }^{92}$

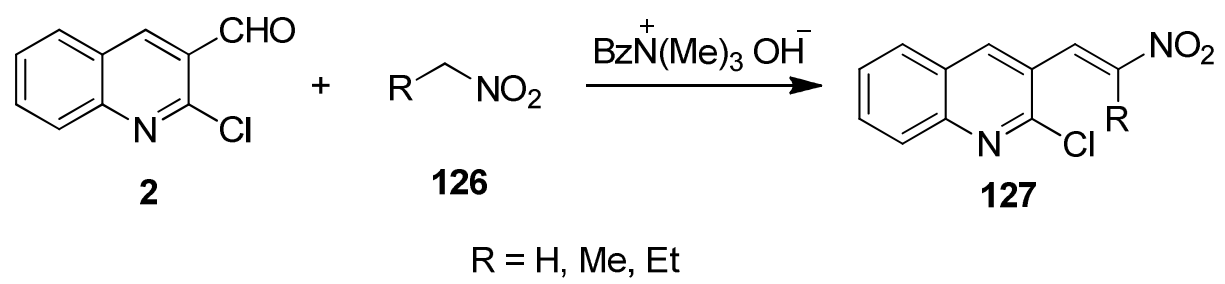

\section{Scheme 45}

Condensation reaction of 4-hydroxy-2-methylquinolines $\mathbf{1 2 8}$ with aldehyde $\mathbf{2}$ in the presence of acetic anhydride, acetic acid and sodium acetate afforded the corresponding 2-[2-(2chloroquinolin-3-yl)ethenyl]quinolin-4(1H)-ones 129, which on cyclization using alcoholic $\mathrm{KOH}$ yields the quinacridine systems $\mathbf{1 3 0}$ in $72-83 \%$ yields (Scheme 46 ). ${ }^{93}$<smiles>[R]c1cc([R])c2[nH]c(/C=C/c3cc4ccccc4nc3Cl)cc(=O)c2c1</smiles>

2

128

$129,82-95 \%$<smiles>[R]c1cc([R])c2[nH]c3ccc4cc5ccccc5nc4c3c(=O)c2c1</smiles>

$130,72-83 \%$

$$
\mathrm{R}=\mathrm{R}^{1}=\mathrm{H} ; \mathrm{R}=\mathrm{Me}, \mathrm{Cl}, \mathrm{R}^{1}=\mathrm{H} ; \mathrm{R}=\mathrm{H}, \mathrm{R}^{1}=\mathrm{Me}
$$

\section{Scheme 46}

The pyrimidine derivatives 131 were synthesized by the cyclocondensation of $\alpha, \beta$ unsaturated ketones $\mathbf{1 1 6} \mathbf{b}$, which were prepared from reaction of aldehyde 55 with substituted acetophenone in the presence of $\mathrm{KOH}$, with thiourea (Scheme 47). ${ }^{48}$ 


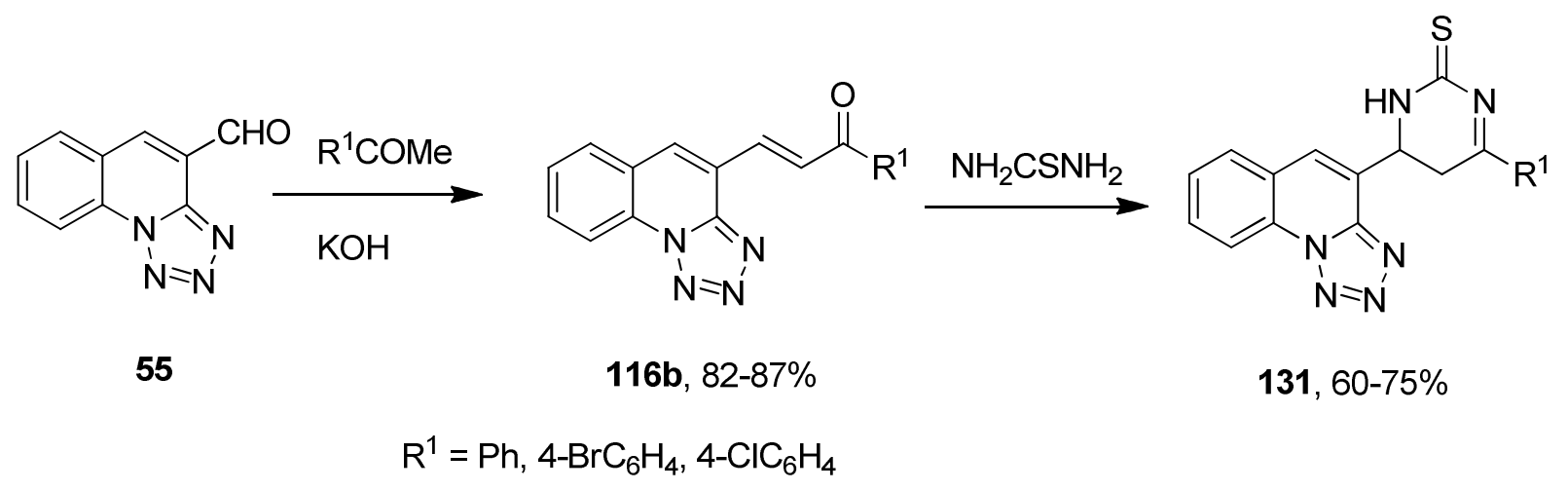

\section{Scheme 47}

One-pot synthesis of 3-(2,6-diarylpyrid-n-4-yl)quinolin-2(1H)-ones $\mathbf{1 3 3}$ in high yield was reported by cyclocondensation reaction under Kröhnke's reaction conditions using aldehyde $\mathbf{2}$, aryl methyl ketone, and various $N$-phenacylpyridinium bromides $\mathbf{1 3 2}$ in a mixture of ammonium acetate and acetic acid under microwave irradiation (Scheme 48). The synthesized compounds were screened for their antimicrobial activities. ${ }^{94-95}$

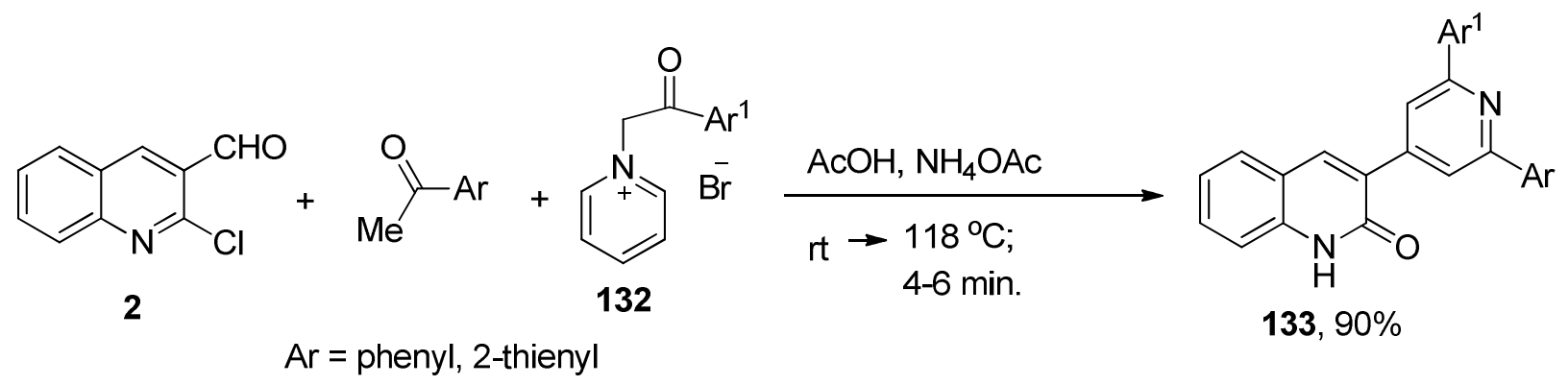

\section{Scheme 48}

The interaction of aldehydes 2 with either $1 H$-benzimidazol-2-ylacetonitrile $134 a,{ }^{96}$ or 2-(4oxo-3,4-dihydroquinazolin-2-yl)acetonitriles $\mathbf{1 3 4 b},{ }^{97}$ in DMF in the presence of $\mathrm{Et}_{3} \mathrm{~N}$ at reflux temperature, gave benzimidazo[1,2-a]benzo[ $g][1,8]$ naphthyridine-6-carbonitrile 135a and 15oxo-15H-benzo[6,7][1,8]naphthyridino[2,1- $b]$ quinazoline-6-carbonitrile $\mathbf{1 3 5 b}, \quad$ respectively (Scheme 49). 


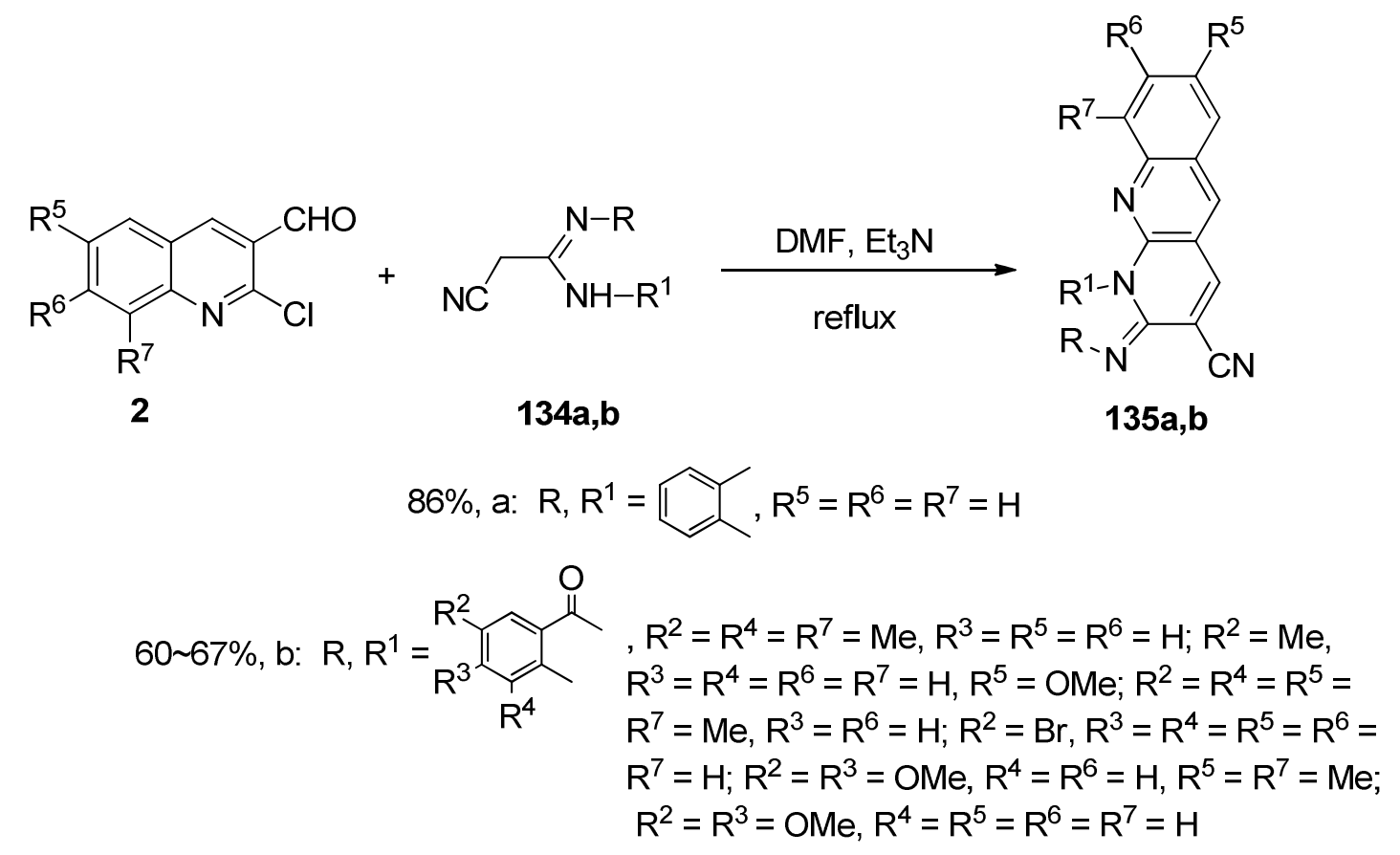

\section{Scheme 49}

12-(2-Chloro-6-quinolin-3-yl)-2,3,4,12-tetrahydro-1H-benzothiazolo[2,3- $b$ ] quinazolin-1-one 138 was synthesized in one pot by condensing aldehyde 2, 2-amino-6-methoxybenzothiazole 136, and 5-dimethyl-1,3-cyclohexanedione 137a in ethanol (Scheme 50 ). ${ }^{98}$<smiles>CCOc1ccc2nc(N)sc2c1</smiles>

\section{Scheme 50}

Biginelli reaction of aldehyde 2 with urea or thiourea and active methylene compounds such as ethyl acetoacetate 139, ${ }^{99}$ 3-methyl-1-phenyl- $H$-pyrazol-5(4H)-one $140,{ }^{100}$ 4-hydroxy-2Hchromen-2-one 141, ${ }^{101}$ dimedone $\mathbf{1 3 7 a},{ }^{102}$ or cyclohexane-1,3-dione $\mathbf{1 3 7 \mathbf { b }},{ }^{103}$ was performed by using either microwave irradiation, ${ }^{99-101-103}$ or by traditional methods in the presence of yttriazirconia-based Lewis acid, ${ }^{104}$ silica-supported $(\mathrm{HO})_{3} \mathrm{Si}\left(\mathrm{CH}_{2}\right)_{3} \mathrm{SO}_{3} \mathrm{H}^{105}$ silica-supported zinc chloride catalyst, ${ }^{106}$ or hydrochloric acid, ${ }^{102}$ to give 4-(2-chloro-3-quinolinyl)-2-oxo/thio- 
pyrimidine 142-145 (Scheme 51). Compounds 143 and 145 were found to be active anticancer agents against lung, breast and CNS carcinomas, ${ }^{100}$ and were screened for their antimicrobial activities, respectively. ${ }^{102}$

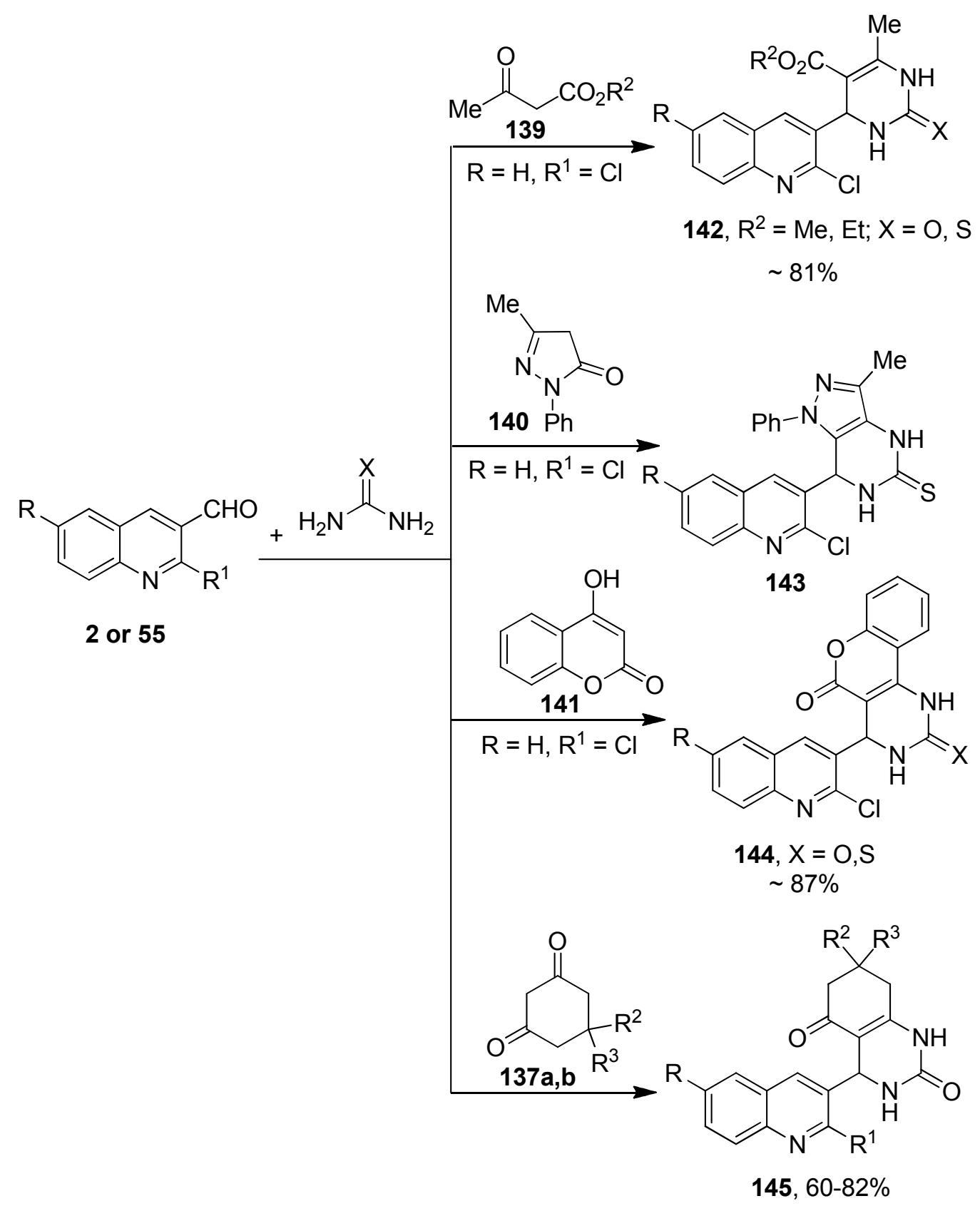

$\mathrm{R}=\mathrm{H}, \mathrm{Me}, \mathrm{MeO}, \mathrm{Cl} ; \mathrm{R}^{1}=\mathrm{Cl}, \mathrm{N}_{3} ; \mathrm{R}^{2}=\mathrm{R}^{3}=\mathrm{H}, \mathrm{Me}$

\section{Scheme 51}


Similarly, pyrimido[4,5- $d$ ]pyrimidine derivatives 147 were synthesized by reaction of aldehyde 2, barbituric acid 146 and urea/thiourea using either solid support of alumina ${ }^{107}$ or water ${ }^{108}$ under microwave irradiation (Scheme 52).<smiles>O=Cc1cc2ccccc2nc1Cl</smiles>

2<smiles>O=C1CC(=O)[NH2+]C(=O)N1</smiles>

146

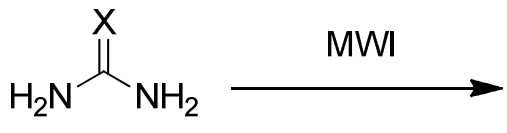

$\mathrm{X}=\mathrm{S}, \mathrm{O}$<smiles>[X]C1Nc2[nH]c(=O)[nH]c(=O)c2C(c2cc3ccccc3nc2Cl)N1</smiles>

$147, \sim 95 \%$

\section{Scheme 52}

2'-Chloro-2,3'-biquinolin-4(1H)-ones $\mathbf{1 4 8}$ were obtained by one-pot microwave-mediated multicomponent reaction of aldehyde $\mathbf{2}$, aryl methyl ketone, and ammonium acetate using piperidine as a catalyst (Scheme 53). The antibacterial activity of the synthesized compounds were determined against gram-positive and gram-negative bacteria and their antifungal activity was determined. ${ }^{109}$<smiles>ClCc1cc2ccccc2nc1Cl</smiles>

2

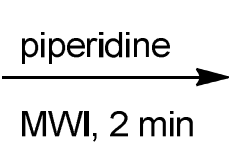

$\mathrm{MWI}, 2 \mathrm{~min}$

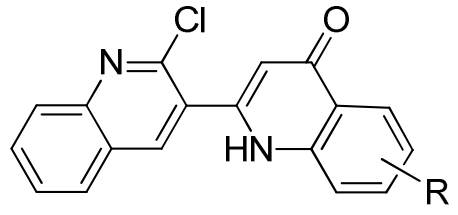

$148,83 \%$

\section{Scheme 53}

Biquinoline adducts 151 were synthesized in high yields by cyclization of [(2-chloro-3quinolyl)methylene]methane-1,1-dicarbonitriles 149, which was provided from reaction between aldehyde 2 and malononitrile, with 3-arylamino-5,5-dimethyl-cyclohex-2-en-1-ones 150 under microwave irradiation catalyzed by 4 -( $N, N$-dimethylamino)pyridine (DMAP) (Scheme 54$)$. The synthesized compound was screened for their antifungal and antibacterial activity. ${ }^{10}$ 
<smiles></smiles><smiles>CC(C)OC1=CC(=O)CC(C)(C)C1</smiles><smiles>Cc1ccc2nc(Cl)c(C3C(C#N)=C(N)N([Al])C4=C3C(=O)CC(C)(C)C4)cc2c1</smiles>

\section{Scheme 54}

Synthesis of $\beta$-acetamido ketone $\mathbf{1 5 2}$ in high yields was described by one-pot threecomponent reaction of aldehyde 2, 4-bromoacetophenone and acetonitrile using cerium (IV) sulfate as a catalyst (Scheme 55). ${ }^{111}$

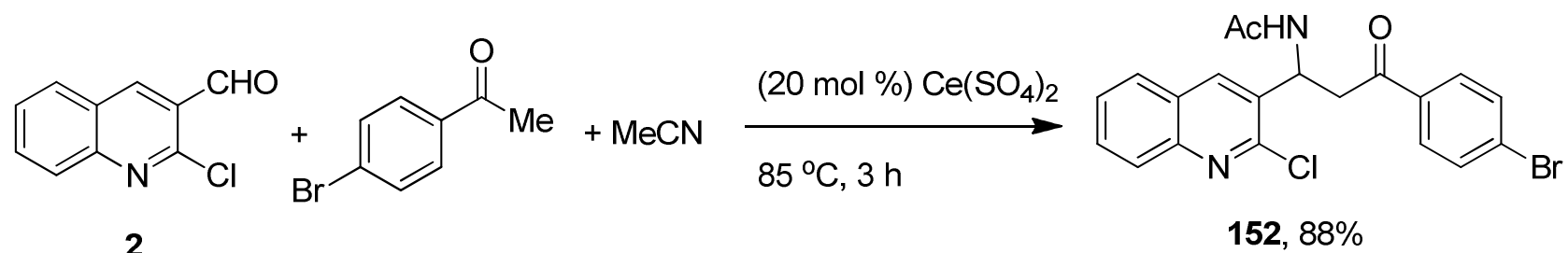

\section{Scheme 55}

Condensation of chloromethylphenyl sulfone 153 with aldehyde 2 using solid sodium hydroxide as catalyst in methanol at room temperature to yield 2-chloro-3-(2-chloro-2(phenylsulfonyl)vinyl)quinoline 154 was reported (Scheme 56). The later compound showed antimalarial activity against cultured Plasmodium falciparum, hemozoin formation, $\mathrm{Hb}$ hydrolysis, and murine malaria model. ${ }^{112}$

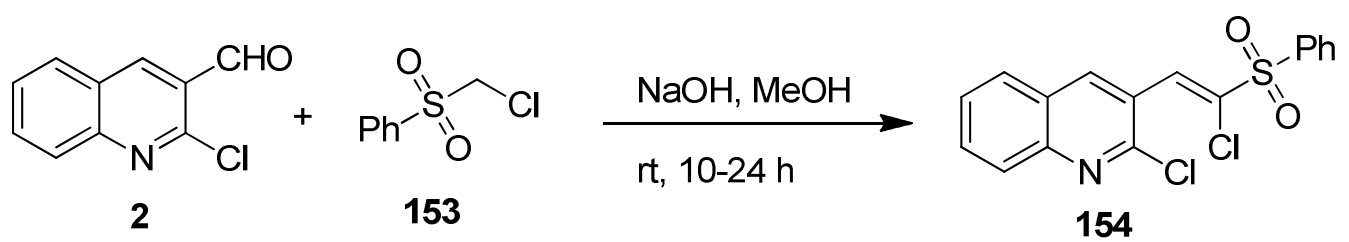

\section{Scheme 56}


The 3-arylideneindolinone 156 was synthesized by refluxing 1-(2,6-dichlorophenyl)indolin2-one 155 with aldehyde 2 in ethanol using piperidine as catalyst (Scheme 57). The synthesized compound was screened for their in vitro cytotoxic activity on SW620 colon cancer cell lines. ${ }^{113}$<smiles>C[Sb](C)(C)(C)CC[C@H](O)c1ccc(Cl)c(N2C(=O)Cc3ccccc32)c1Cl</smiles>

\section{Scheme 57}

Condensation of aldehyde 2 with 4-hydrazonopentan-2-one 157 in the presence of alc. $\mathrm{KOH}$ led to 4-acetyl-3-methyl[1,2]diazepino[3,4-b]quinoline 158 ( Scheme 58). The later compound was screened for antimicrobial activity. ${ }^{114}$<smiles>O=Cc1cc2ccccc2nc1Cl</smiles>

2<smiles>CC(=[NH2+])CC(C)=O</smiles>

157

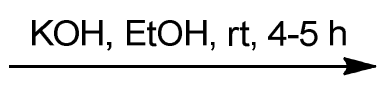<smiles>CC(=O)C1=Cc2cc3ccccc3nc2NN=C1C</smiles>

$158,52 \%$

\section{Scheme 58}

A direct three component Mannich-type reaction of aldehyde 2, aniline, and acetophenone was efficiently catalyzed by an yttria-zirconia based strong Lewis acid in aqueous acetonitrile to give 3-(2-chloroquinolin-3-yl)-1-phenyl-3-(phenylamino)propan-1-one 159 (Scheme 59). ${ }^{115}$

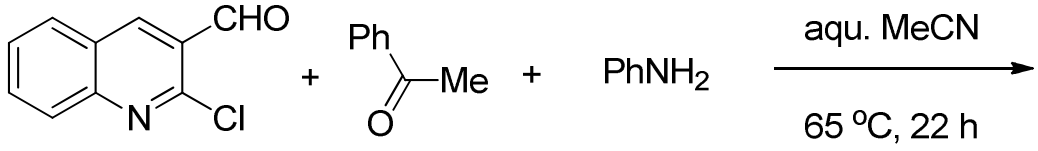

2<smiles>O=C(CC(Nc1ccccc1)c1cc2ccccc2nc1Cl)c1ccccc1</smiles>

$159,45 \%$

Scheme 59 
The Knoevenagel condensation reaction of aldehyde $\mathbf{2}$ with ethyl cyanoacetate was carried out under ultrasonic irradiation catalyzed by 1,8-diazabicycloundec-7-ene (DBU) at room temperature under solvent-free conditions to afford (E)-ethyl 3-(2-chloroquinolin-3-yl)-2cyanoacrylate 160 (Scheme 60). ${ }^{116}$<smiles>CCOC(=O)CC#N</smiles>

2

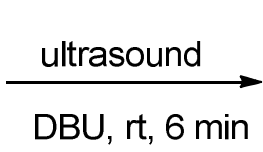

$\mathrm{DBU}, \mathrm{rt}, 6 \mathrm{~min}$<smiles>CCOC(=O)/C(C#N)=C/c1cc2ccccc2nc1Cl</smiles>

$160,90 \%$

\section{Scheme 60}

The reaction between aldehyde 2 and thioglycolic acid in refluxing ethanol containing sodium hydroxide and potassium iodide, afforded a mixture of [(3-formylquinolin-2yl)thio]acetic acids 162 and thieno[2,3- $b$ ]quinoline-2-carboxylic acids 161. The uncyclized compounds 162, on refluxing with $\mathrm{POCl}_{3}$ in various alcoholic media, gave [(3-formylquinolin-2yl)thio]acetates 163. Further cyclization was achieved by refluxing them with DMF to produce thieno[2,3-b]quinoline derivatives $\mathbf{1 6 4}^{117}$ On the other hand, thieno[2,3-b]quinoline-2carboxylic acids and its alkyl esters 164 were synthesized by condensation of aldehyde 2 with thioglycolic acid/alkyl esters under microwave irradiation using anhydrous potassium carbonate (Scheme 61). ${ }^{118}$ The synthesized compounds showed moderate antimicrobial activity, ${ }^{118}$ and evaluated for their activity to inhibit $\beta$-hematin formation and $\mathrm{Hb}$ hydrolysis in vitro and in vivo. ${ }^{119}$

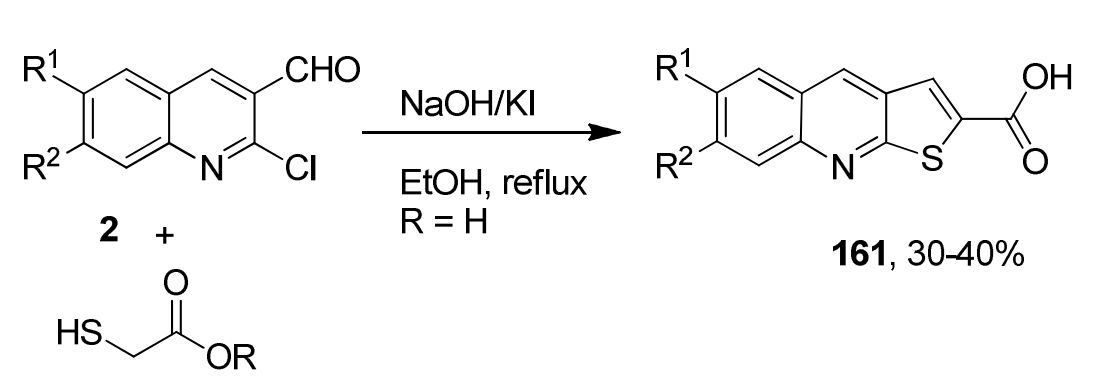<smiles>[R]c1cc2cc3cc(C(=O)O[R17](C)(C)C)sc3nc2cc1[R]</smiles><smiles>[R]c1cc2cc(C=O)c(SCC(=O)O)nc2cc1[R]</smiles>

$162,60-70 \%$<smiles>[R20]OC(=O)CSc1nc2ccccc2cc1C(=O)O[R6]([R6])([H])C</smiles>

$$
\mathrm{R}^{1}=\mathrm{H}, \mathrm{Me}, \mathrm{F}, \mathrm{Br} ; \mathrm{R}^{2}=\mathrm{H}, \mathrm{Cl} ; \mathrm{R}^{3}=\mathrm{Me}, \mathrm{Et}, i-\mathrm{pr}
$$

\section{Scheme 61}


Reaction of 2,4,6-trichloropyrimidine 165 with sodium hydroxide to give 6-chlorouracil 166 in $71 \%$ yield. Next, 6-chlorouracil $\mathbf{1 6 6}$ was heated at melt temperature with the aniline followed by heating the resulting 6- $N$-aryl-aminouracil 167 with aldehyde 2 in DMF to afford 5deazaflavin 168 (Scheme 62). ${ }^{120}$ The compound act as a low molecular weight inhibitor of the E3 activity of HMD2 in tumors that retain wild-type p53. ${ }^{120}$<smiles>O=C1CC(Nc2ccccc2)=NC(=O)N1</smiles><smiles>O=Cc1cc2ccccc2nc1Cl</smiles>

$168,62 \%$

\section{Scheme 62}

The three-component reaction of aldehyde 2, malononitrile, and either 4-hydroxycoumarin 141 or resorcinol was performed in aqueous $\mathrm{K}_{2} \mathrm{CO}_{3}$ under microwave irradiation to give 2amino-4-(2-chloroquinolin-3-yl)-5-oxo-4,5-dihydropyrano[3,2-c]chromene-3-carbonitrile $\mathbf{1 6 9}^{121}$ and 2-amino-4-(2-chloroquinolin-3-yl)-7-hydroxy-4H-chromene-3-carbonitrile $\mathbf{1 7 0}^{122}$ respectively, in excellent yields (Scheme 63). Compound $\mathbf{1 7 0}$ was shown to possess antibacterial activity as tested in vitro against strains of Escherichia coli, Pseudomonas aeruginosa, and Staphylococcus aureus. ${ }^{122}$ 


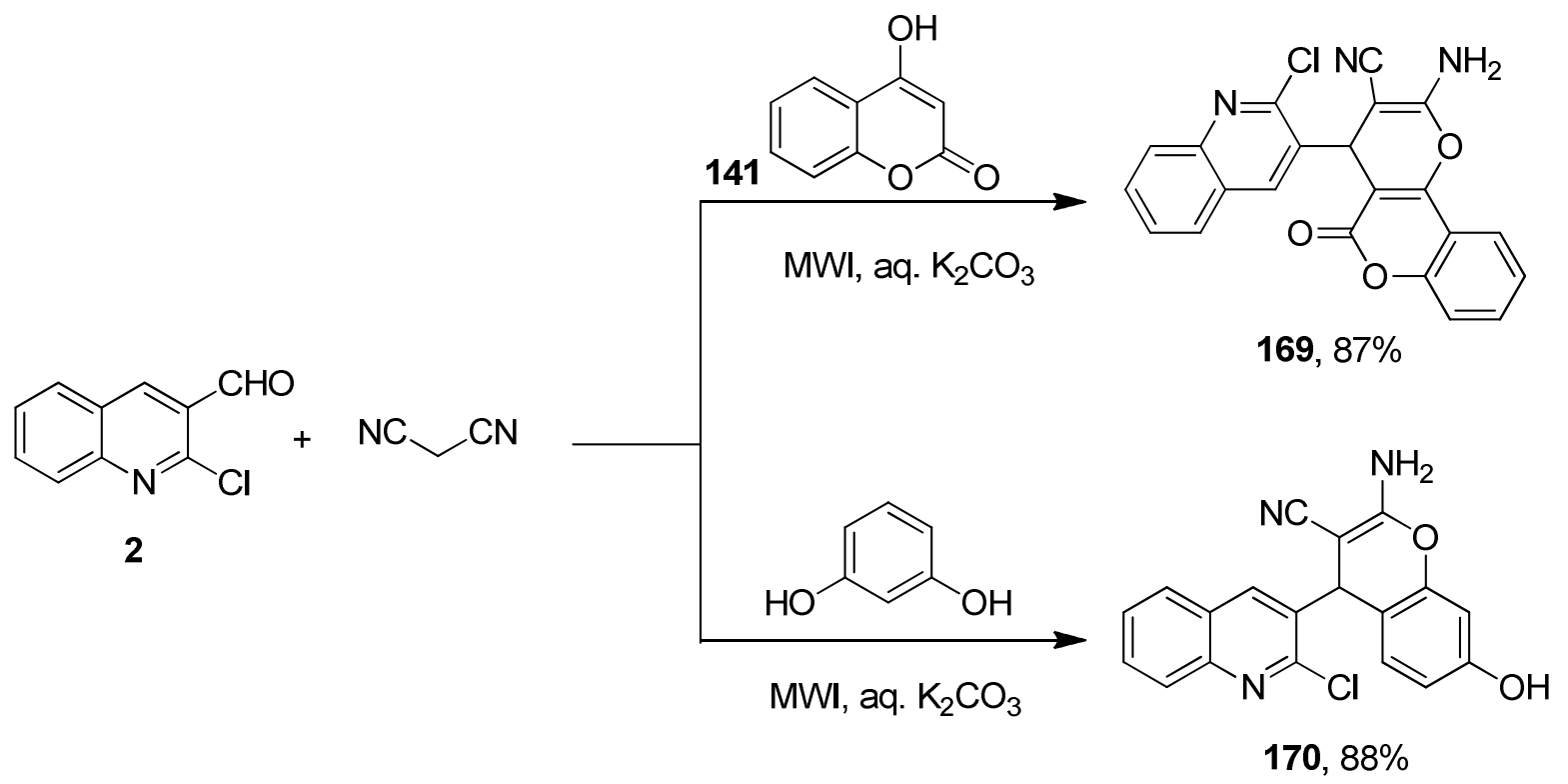

\section{Scheme 63}

A three-component one-pot condensation reaction of aldehyde $2, \beta$-naphthol, and urea (thiourea) in the presence of montmorillonite K10 clay under solvent free conditions to afford 1(2-chloroquinolin-3-yl)-1H-naphtho[1,2-e][1,3]oxazin-3(2H)-one (thione) 171 in excellent yields (Scheme 64). ${ }^{123}$<smiles>O=Cc1cc2ccccc2nc1Cl</smiles>

2<smiles>[X]C(=[NH+])N</smiles>

$X=O, S$<smiles>[X]C1=NC(c2cc3ccccc3nc2Cl)c2c(ccc3ccccc23)O1</smiles>

171

\section{Scheme 64}

Pyridine derivatives 172-174 were synthesized via Hantzsch reaction of aldehyde 2, barbituric acid 146, ${ }^{124}$ or dimedone $137 \mathbf{a},{ }^{97}$ and ammonium salts, either under microwave or under conventionally method using water as the solvent. Aromatization was observed when ammonium nitrate was used as the source of nitrogen (Scheme 65). 


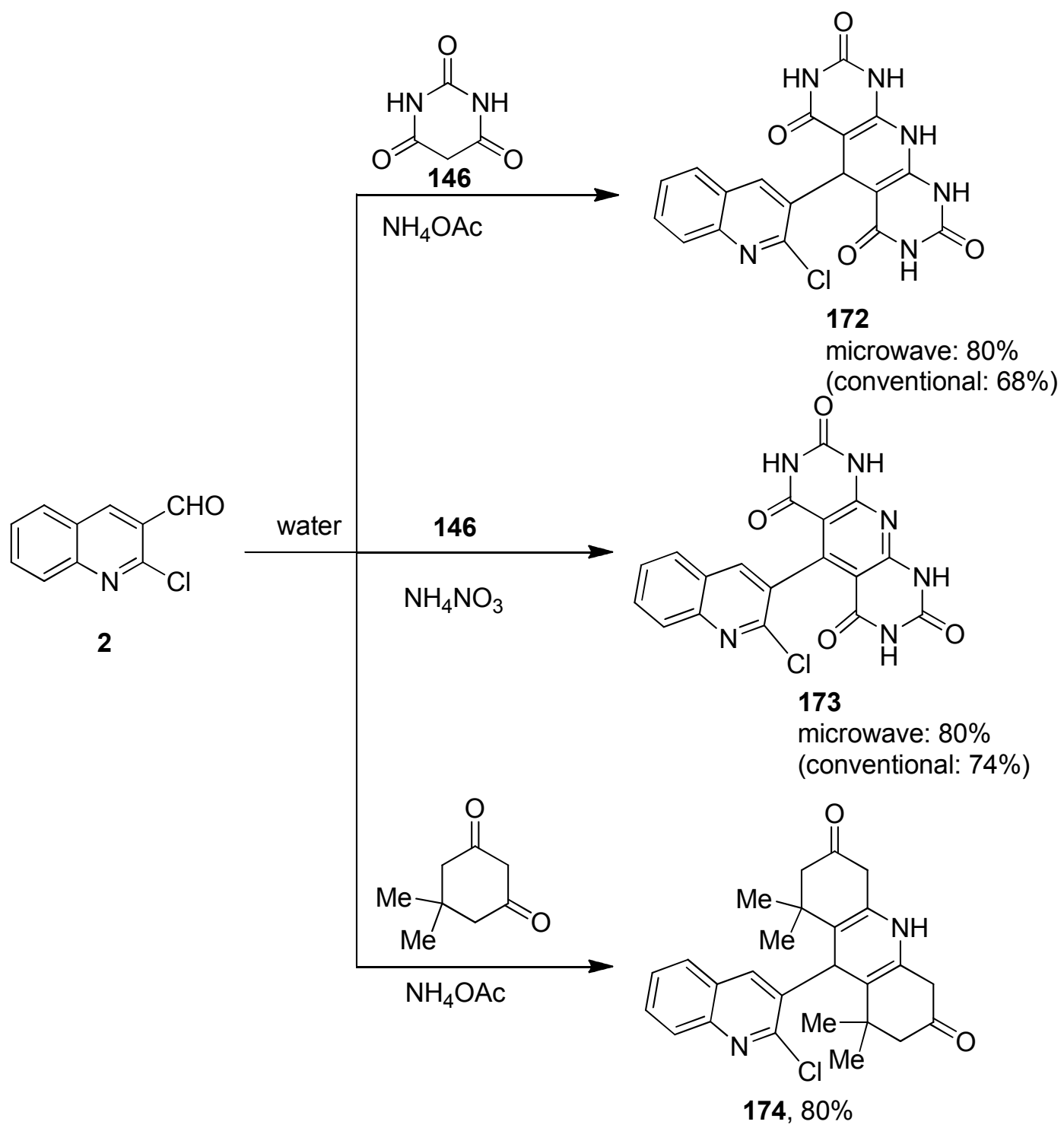

\section{Scheme 65}

Knoevenagel reaction of aldehyde 2 with $\mathrm{CH}$-acidic compounds, such as benzoyl acetonitrile 175 and 1-phenyl-2-(phenylsulfonyl)ethanone 176 in boiling methanol containing few drops of piperidine, afforded 4-(2-oxo-1,2-dihydroquinolin-3-yl)-2,6-diphenyl-4 $H$-pyran-3,5dicarbonitrile 179 and 3-(2-chloroquinolin-3-yl)-1-phenyl-2-(phenylsulfonyl)prop-2-en-1-one 180, respectively in good yield as the sole reaction products (Scheme 66). Similarly, aldehyde 2 was reacted with 1-indanone $\mathbf{1 7 7}$ in boiling ethanol containing few drops of piperidine, reportedly to afford 12,13-dihydroindeno[5,6]pyrano[2,3-b] quinoline 183, via intermediate 182. On the other hand, treatment of aldehyde 2 with 2-cyano- $N$ '-(1-(furan-2yl)ethylidene)acetohydrazide $\mathbf{1 7 8}$ in refluxed methanol containing piperidine, gave 3-(2chloroquinolin-3-yl)-2-cyano- $N^{\prime}$-(1-(furan-2-yl)ethylidene)acrylohydrazide 184 (Scheme 66). ${ }^{6}$ 


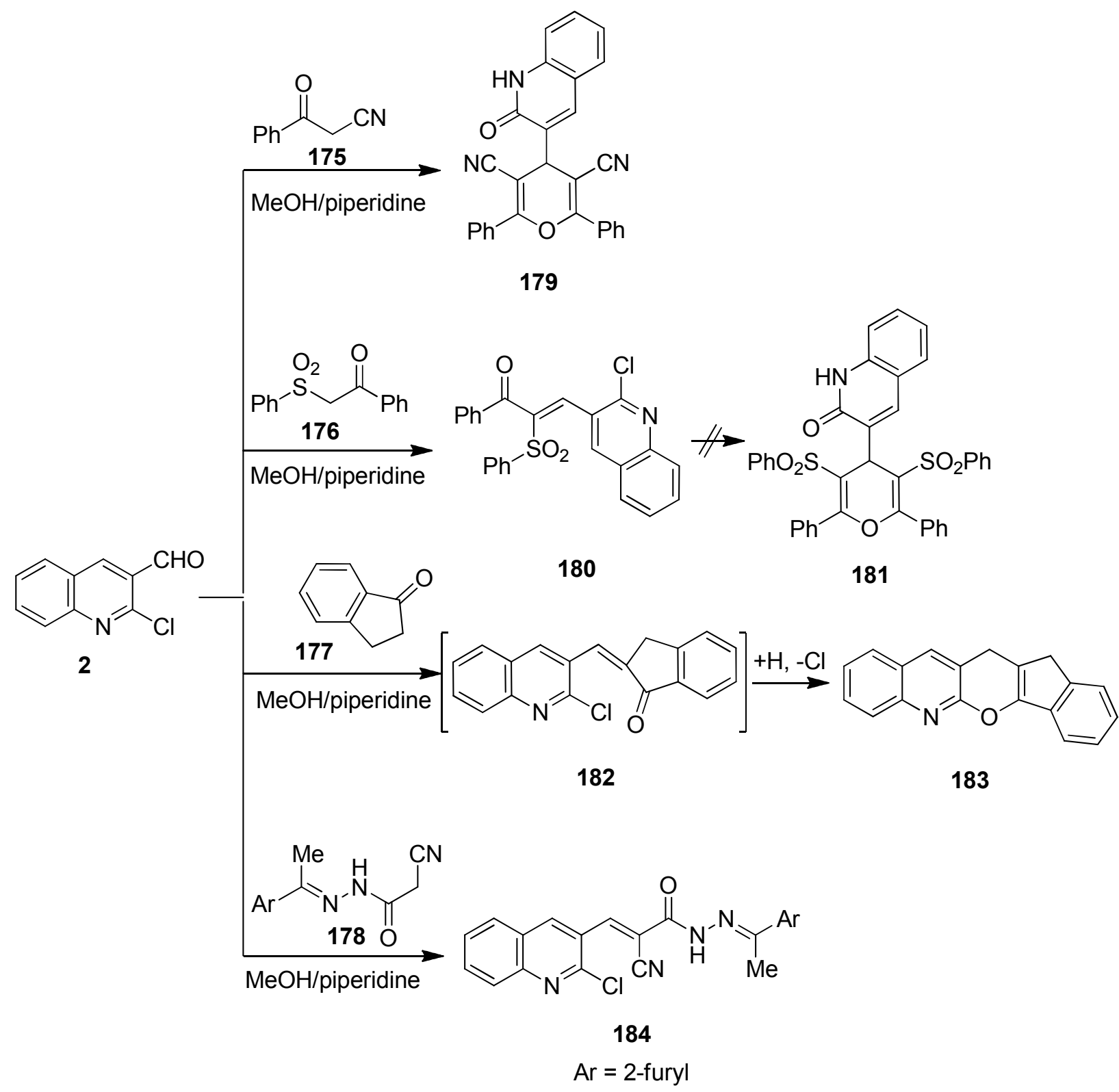

\section{Scheme 66}

3.4.2 Reactions with hydrazine, hydroxylamine, hydrazides, (thio)semicarbazide, and (thio)urea. 2-Chloroquinoline-3-carbaldehyde 2 reacted with hydroxylamine, hydrazine or arylhydrazine, urea, thiourea, ${ }^{125}$ either by traditional methods ${ }^{15}$ in acetic acid or by solvent-free microwave-induced techniques using PTSA as a catalyst, ${ }^{126,127}$ or potassium carbonate in DMF, ${ }^{128}$ to afford isoxazolo[5,4- $b$ ]quinoline 185 , pyrazolo[3,4- $b$ ]quinolines 186 , pyrimido[4,5$b$ ]quinolin-2-ol 187a, and pyrimido[4,5-b]quinoline-2-thiol 187b, respectively in good to excellent yields (Scheme 67). The synthesized compounds have higher analgesic activity than 
noramidopyrine (NAP), ${ }^{15}$ and they were evaluated for their antibacterial and antifungal activities, most of them showing activity against Escherichia coli and Pseudomonas aeruginosa. ${ }^{126,129}$

On the other hand, pyrazolo[3,4-b]quinolines $186\left(\mathrm{R}_{1}=\mathrm{H}, \mathrm{Ph}\right)$ were obtained with better to excellent yield (91\%), when one-pot condensation of aldehyde 2 and molar excess of hydrazine hydrate/phenyl hydrazine was carried in water for $7 \mathrm{~h}$ using thermal energy. ${ }^{43,130}$ The same condensation take place when the reaction is carried out in water under microwave irradiation $(93 \%, 1.5 \mathrm{~h})\left(\right.$ Scheme 67). ${ }^{43}$

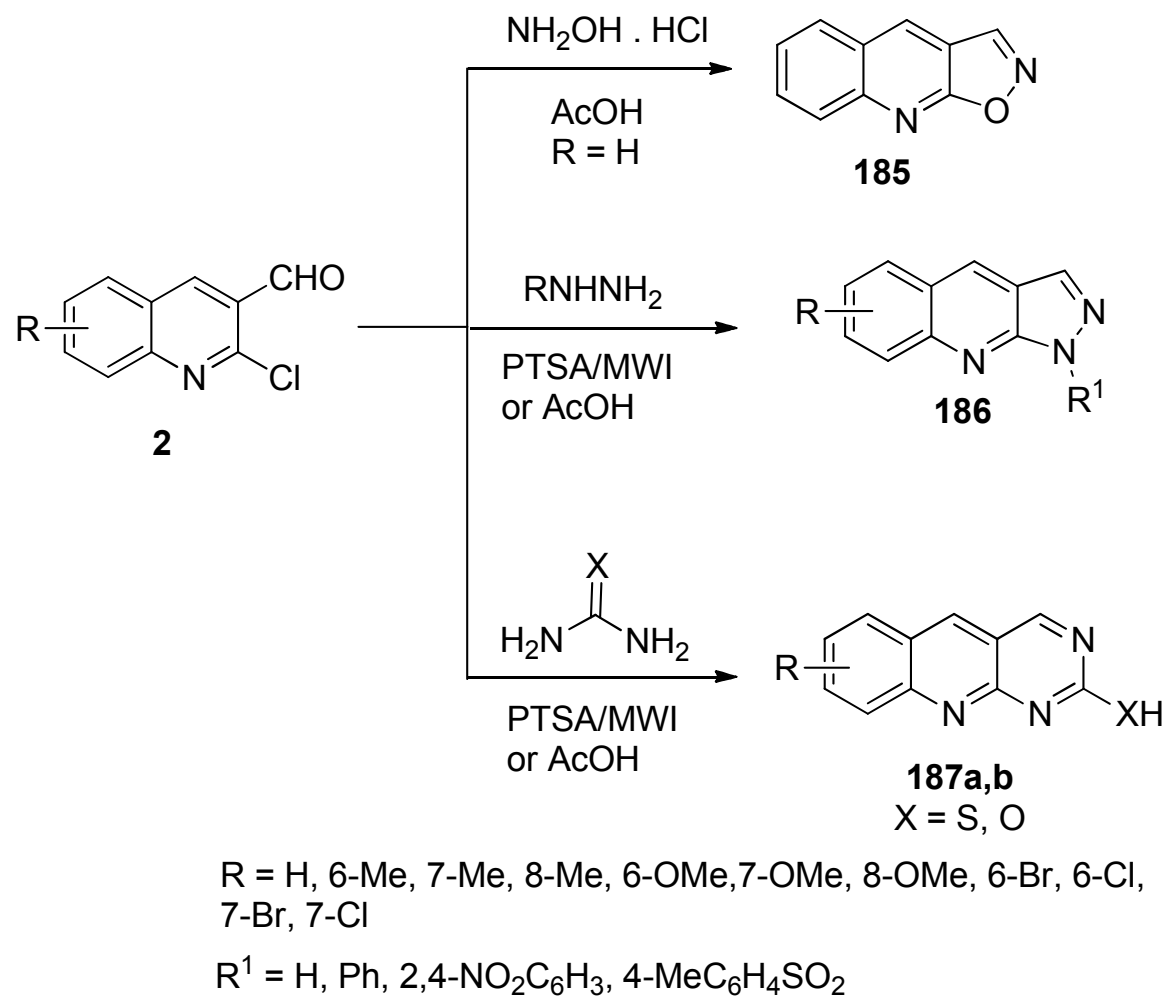

\section{Scheme 67}

One-pot synthesis of pyrimido[4,5- $b$ ]quinolines 189 were achieved from reaction of aldehydes 2 and guanidinium nitrate $\mathbf{1 8 8}$ (Scheme 68). All the synthesized compounds were biologically screened for their antibacterial activity. ${ }^{131}$<smiles>[R]c1cccc2cc(C=O)c(Cl)nc12</smiles>

2<smiles>N=C(N)[18O][N+](=O)[O-]</smiles>

188<smiles>[R]c1nc2nc(N)ncc2cc1/C=C\C</smiles>

189

\section{Scheme 68}


One-step synthesis of 1-phenylpyrimido[4,5-b]quinoline-2(1H)-thiones $\mathbf{1 9 1 a},{ }^{132}$ or -ones 191b 90 were achieved from reaction of aldehydes 2 with $N$-phenylthiourea 190a or $N$ phenylurea 190b, respectively (Scheme 69). The synthesized compounds were biologically screened for their antibacterial and antifungal activities.

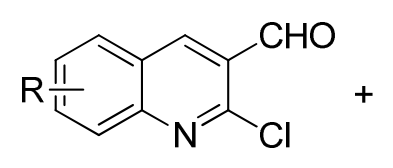

2

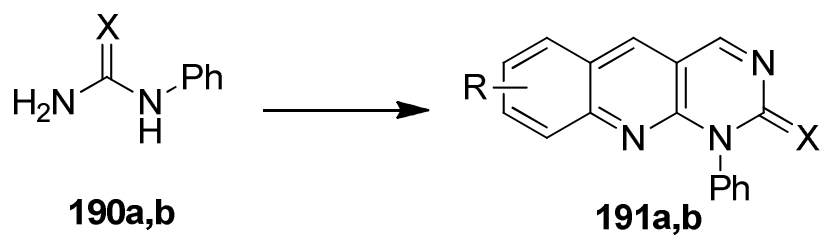

$\mathrm{R}=$ alkyl, alkoxy, halo; $\mathrm{X}=(\mathrm{a}) \mathrm{S},(\mathrm{b}) \mathrm{O}$

\section{Scheme 69}

Synthesis of pyrazolo[3,4- $b$ ]quinolines 193 was reported from direct reaction of aldehydes 2 with hydrazine was unsuccessful, because the formed hydrazone had $E$ geometry and thus was sterically prevented from attacking the quinoline C-2. In order to avoid this difficulty, the aldehydes 2 were converted into acetals 91. that reacted with hydrazine hydrate in refluxing ethanol gave the quinolin-2-ylhydrazines 192 in good yields. Finally, mild aqueous acidic removal of the acetal protection led directly, in one pot, to the cyclized $1 H$-pyrazolo[3,4- $b]$ quinolines 193 (Scheme 70). ${ }^{133,134}$

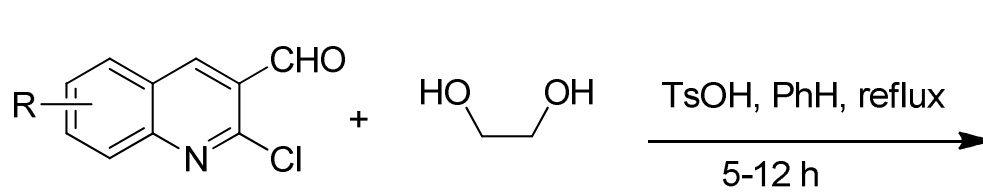

2<smiles>[R]=CC=c1nc(Cl)c(C2OCCO2)cc1=C1C=[R]=CC=C1</smiles>

91, $85 \%$

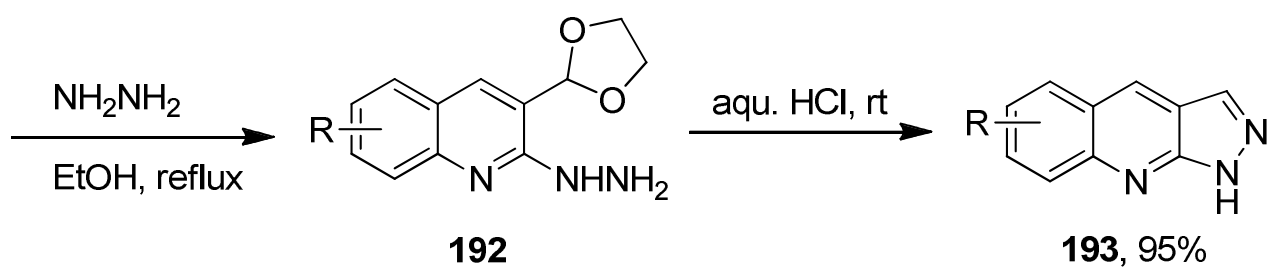

$\mathrm{R}=$ 8-Me, 7-Me, 6-Me, 7-MeO, 6-MeO

\section{Scheme 70}

2-Chloroquinoline-3-carbaldehyde [arylmethylene]hydrazones 195 were synthesized from reaction of aldehyde 2 with hydrazine to give hydrazone 194 followed by reaction with substituted aldehydes (Scheme 71). The synthesized derivatives were screened for antibacterial and antifungal activities. ${ }^{135}$ 


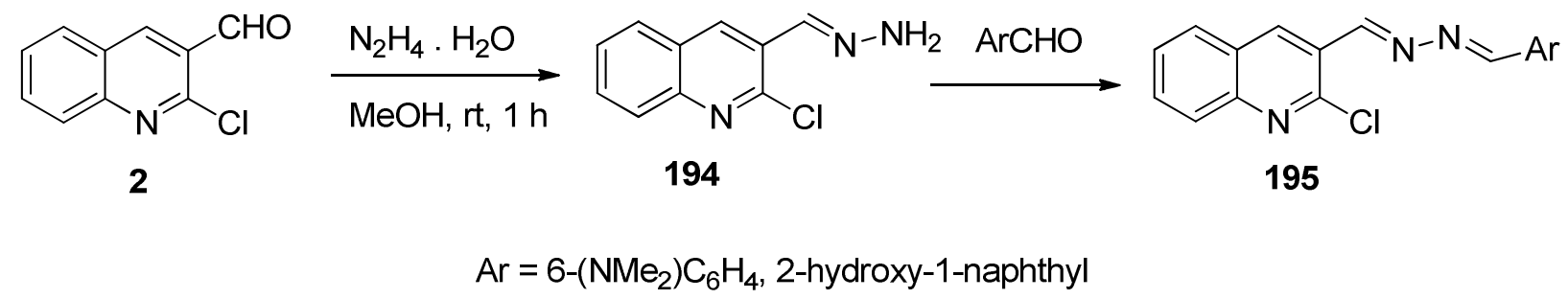

\section{Scheme 71}

1,8-Naphthyridinyl pyrazolo[3,4- $b]$ quinolines 197 were synthesized by reaction of 2-hydrazino-3-(4-methoxyphenyl)-1,8-naphthyridine 196 with aldehydes 2 followed by cyclization with $\mathrm{DMF} / \mathrm{KOH}$ either by microwave irradiation or by conventional methods. The reaction rate is enhanced tremendously under microwave irradiation as compared to conventional method with improved yields (Scheme 72). ${ }^{136}$

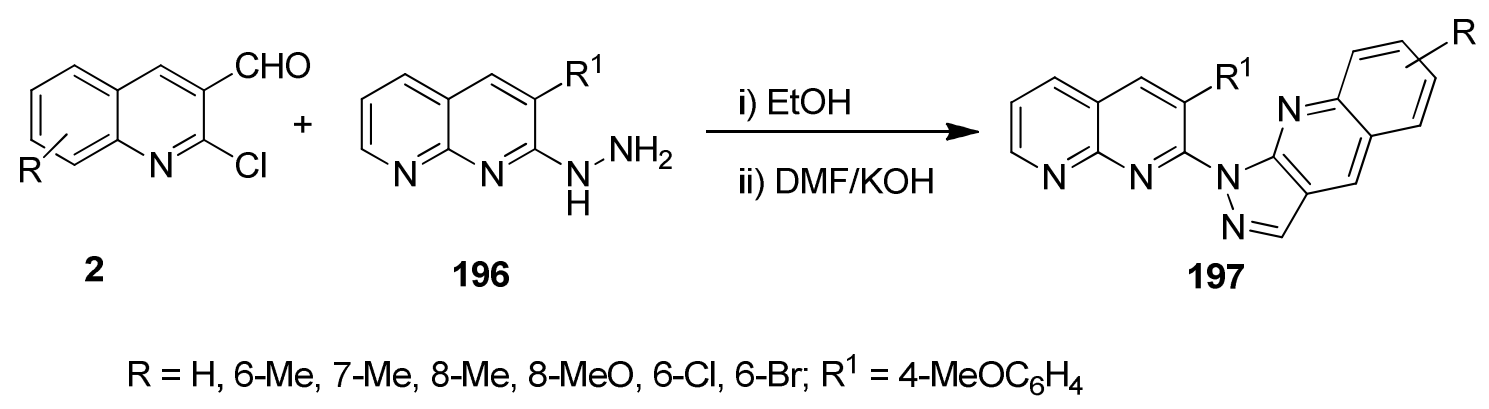

\section{Scheme 72}

The aldehydes 2 underwent condensation with thiosemicarbazide 198 to give the corresponding thiosemicarbazones 199, which on treatment with phenacyl bromides, gave thiazoles 200. The dehydrogenative cyclization of $\mathbf{2 0 0}$ was achieved with chloranil, in refluxing toluene, resulting in 3-(2-chloroquinolin-3-yl)-5-arylthiazolo[2,3-c][1,2,4]triazoles 161 (Scheme 73). ${ }^{137}$ 
<smiles>[R]c1ccc2nc(Cl)c(C=O)cc2c1</smiles>

2<smiles>[R]C(=N)/C=C\CNN</smiles>

198<smiles>[R1]c1ccc2nc(Cl)c(/C=N\NC(N)=S)cc2c1</smiles>

199<smiles>[R]C(C)C(=O)CBr</smiles><smiles>[R1]c1ccc2nc(Cl)c(/C=N\Nc3nc([R])cs3)cc2c1</smiles>

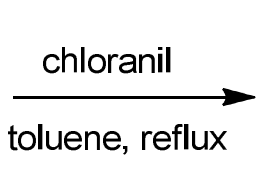

toluene, reflux<smiles>[R]c1ccc2nc(Cl)c(-c3nnc4scc([R])n34)cc2c1</smiles>

$$
\mathrm{R}^{1}=\mathrm{H}, \mathrm{Me} ; \mathrm{R}^{2}=\mathrm{Ph}, 4-\mathrm{MeC}_{6} \mathrm{H}_{4}, 4-\mathrm{BrC}_{6} \mathrm{H}_{4}, 4-\mathrm{ClC}_{6} \mathrm{H}_{4}
$$

\section{Scheme 73}

5-(2-Chloroquinolin-3-yl)-6-hydroxy-8-mercapto-4,5-dihydro-1 $H$-pyrimido[4,5-e][1,2,4]triazepine-2(3H)-thione $\mathbf{2 0 2}$ was prepared under microwave irradiation either by one pot reaction of aldehyde 2, thiosemicarbazide 198a, and thiobarbituric acid 146b using montmorillonite K-10 clay or by two steps. Firstly, thiosemicarbazide 198a was condensed with aldehyde 2 using neutral alumina/montmorillonite K-10 clay resulting in thiosemicarbazone 199. Then in the second step, the later compound was allowed to react with thiobarbituric acid 146b, over alumina/clay that cyclized to afford target compounds (Scheme 74). ${ }^{138}$

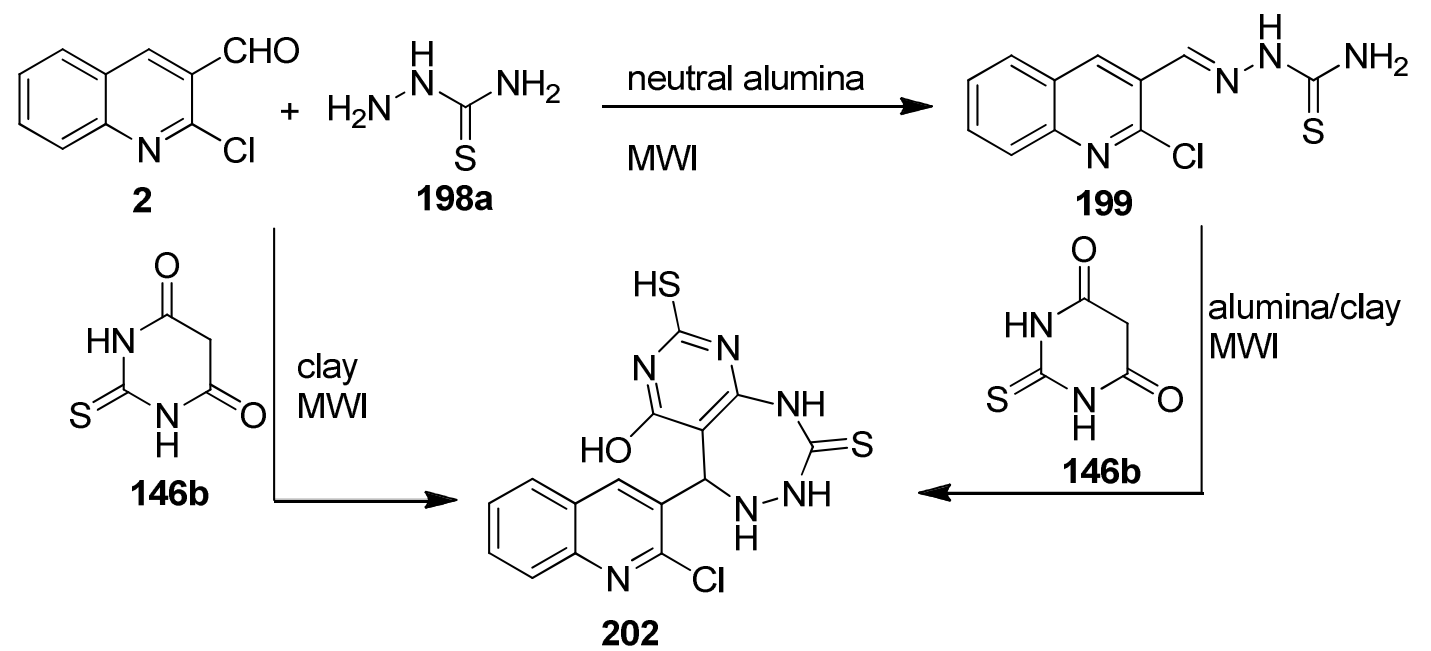

\section{Scheme 74}


2-Hydrazinyl[1,3,4]thiadiazepino[7,6- $b$ ]quinolines 204 were obtained in good yields by one pot reaction of aldehyde 2 with carbidimide 202 in DMF in the presence of $p$-TsOH as a catalyst under microwave irradiation (Scheme 75). ${ }^{139,140}$

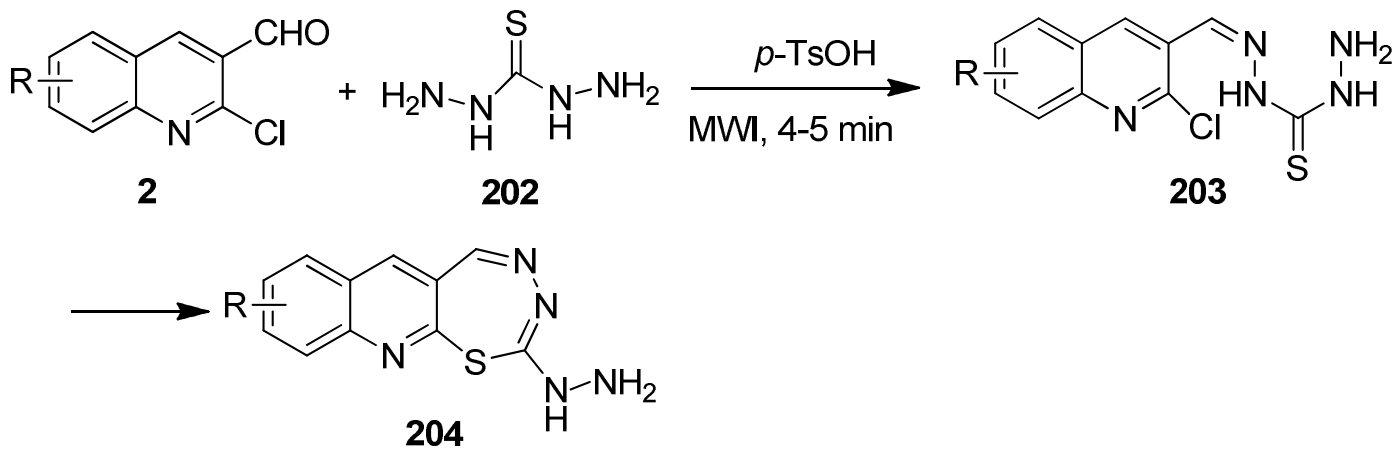

$$
\mathrm{R}=\mathrm{H}, \mathrm{R}=\text { 7-Me, 6-Me, 8-Me, 6-Cl, 7-OMe, 8-OMe, 6-OMe }
$$

\section{Scheme 75}

Condensation of tetrazolo[1,5-a]quinoline-4-carbaldehyde 55 with substituted thiosemicarbazides 205 afforded the corresponding thiosemicarbazones 206. The later compounds underwent cyclization with malonic acid in the presence of acetyl chloride to give the pyrimidine derivatives 207. Condensation of 207 with the appropriate aromatic aldehyde gave rise to arylidene derivatives 208 (Scheme 76). ${ }^{48}$

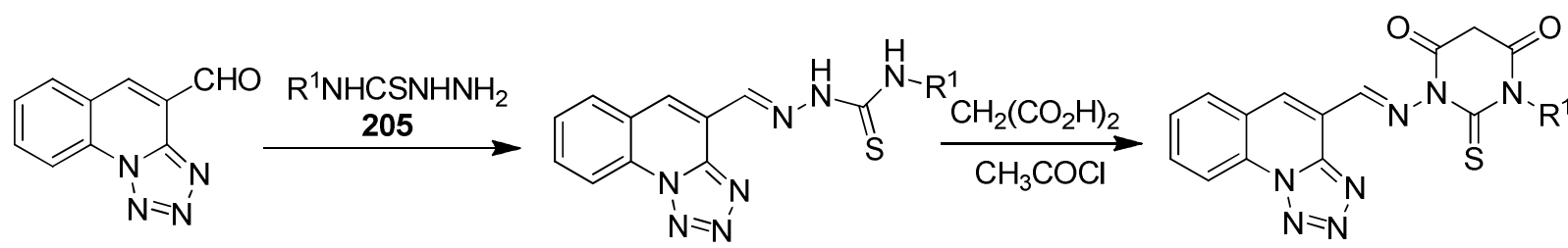<smiles>[R]C=C1C(=O)N([R])C(=S)N(/N=C/c2cc3ccccc3n3nnnc23)C1=O</smiles>

$206,81-85 \%$

207, $76-79 \%$

208, $54-78 \%$

$\mathrm{R}^{1}=\mathrm{Ph}, 4-\mathrm{MeC}_{6} \mathrm{H}_{4}, 4-\mathrm{ClC}_{6} \mathrm{H}_{4} ; \mathrm{R}^{2}=\mathrm{Ph}, 4-(\mathrm{Me})_{2} \mathrm{NC}_{6} \mathrm{H}_{4}$

\section{Scheme 76}


The reaction of aldehyde $\mathbf{2}$ with $N^{\prime}$-(2-aminobenzoyl)methanesulfonohydrazide $\mathbf{2 0 9}$ in refluxing propanol gave $\mathrm{N}$-(2-(2-chloroquinolin-3-yl)-4-oxo-1,2-dihydroquinazolin-3(4H)-yl)methanesulfonamide 210 (Scheme 77). ${ }^{141}$<smiles>O=Cc1cc2ccccc2nc1Cl</smiles>

2<smiles>COS(=O)(=O)NNC(=O)c1ccccc1N</smiles>

209

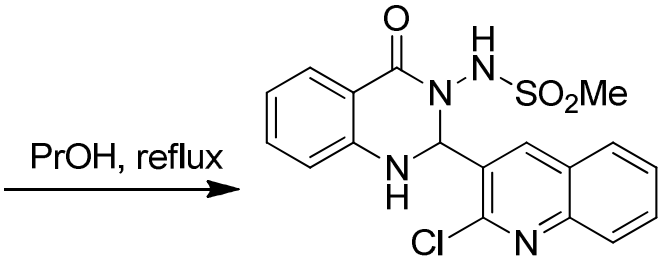

$210,62 \%$

\section{Scheme 77}

The reaction of aldehyde 2 with 2-cyanoacetohydrazide 211 in boiling ethanol containing a few drops of acetic acid to afford $N^{\prime}$-[(2-chloroquinolin-3-yl)methylene]-2-cyanoacetohydrazide 212 in good yield. Condensation of $\mathbf{2 1 2}$ with 2,4-dihydroxybenzaldehyde, 4-fluorobenzaldehyde, and 1-phenyl-3(2-thienyl)-1H-pyrazole-4-carbaldehyde, in methanol in the presence of a few drops of piperidine at reflux temperature, gave $N^{\prime}$-[(2-chloroquinolin-3-yl)methylene]-7hydroxy-2-imino-2H-chromene-3-carbohydrazide 213, $N$-((2-chloroquinolin-3-yl)methylene)-2cyano-3-(1-phenyl-3(2-thienyl)-1H-pyrazol-4-yl)acrylohydrazide $\quad \mathbf{2 1 4 a}, \quad$ and $\quad N^{\prime}$-((2chloroquinolin-3-yl)methylene)-2-cyano-3-(4-fluorophenyl)acrylohydrazide 214b, respectively (Scheme 78). The anti-inflammatory and analgesic activities of the synthesized compounds were evaluated. ${ }^{6}$

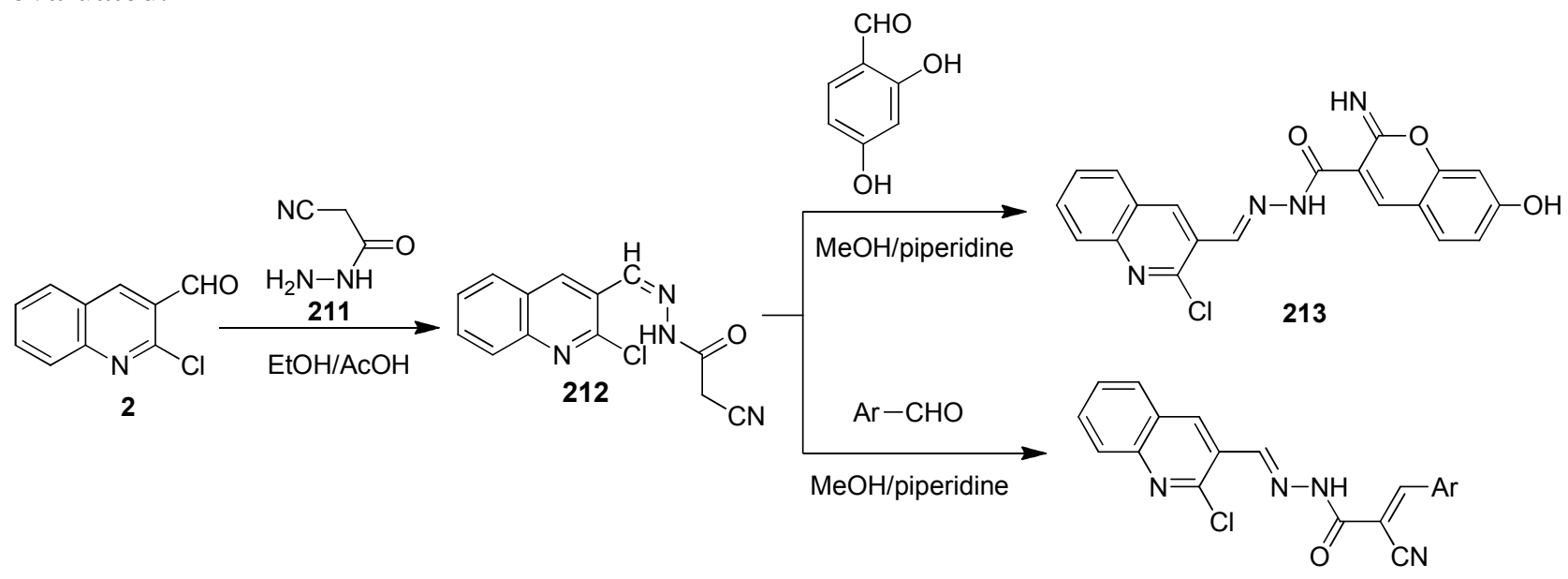

214a, $\mathrm{Ar}=1$-phenyl-3-(thiophen-2-yl)-1H-pyrazole-4-yl b, $\mathrm{Ar}=4-\mathrm{FC}_{6} \mathrm{H}_{4}$

\section{Scheme 78}


(4-(1H-Pyrrol-1-yl)phenyl)(1H-pyrazolo[3,4-b]quinolin-1-yl)methanone 217 was synthesized by reaction of aldehydes 2 with 4-(1H-pyrrol-1-yl)benzohydrazide 215a in microwave irradiation to give $N^{\prime}$-((2-chloroquinolin-3-yl)methylene)-4-(1H-pyrrol-1-yl)benzohydrazide 216 followed by intramolecular cyclization. Compound 217 exhibited moderate to good antibacterial and antitubercular activities (Scheme 79). ${ }^{142}$

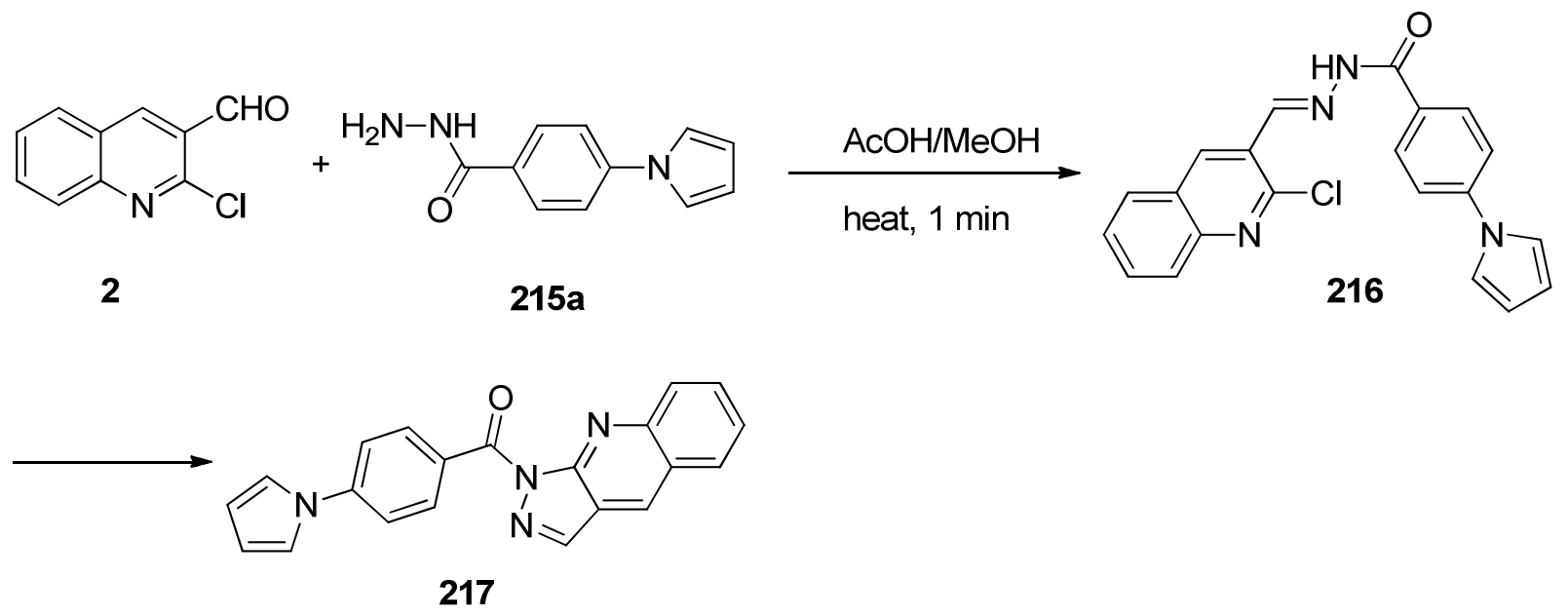

\section{Scheme 79}

2-(Phenylamino)-1-(1H-pyrazolo[3,4- $b$ ]quinolin-1-yl)ethanone 218a, $1 H$-pyrazolo[3,4- $b]$ quinoline-1-carbothioamide 218b, and $1 H$-pyrazolo[3,4- $b$ ]quinoline-1-carboxamide 218c were synthesized by the condensation of aldehyde $\mathbf{2}$ with 2-(phenylamino)acetohydrazide $\mathbf{2 1 5 b}$, thiosemicarbazide 198a, or semicarbazide 198b, respectively (Scheme 80). The synthesized compounds have antibacterial and antifungal activity. ${ }^{143}$

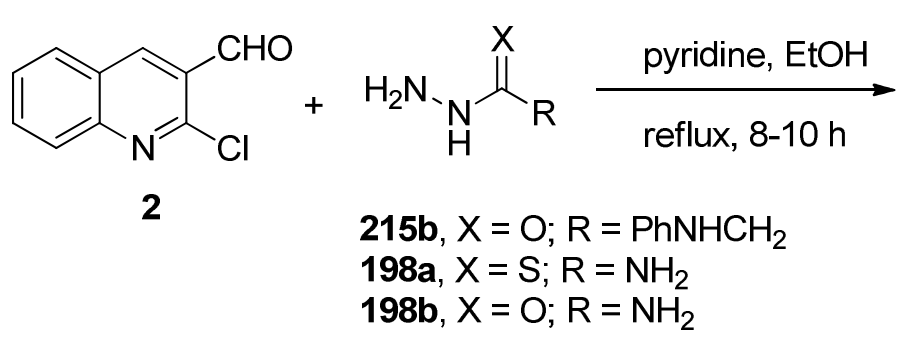

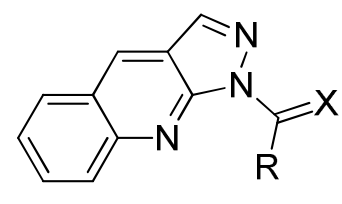

218a-c, $\sim 68 \%$

\section{Scheme 80}

Naphtho[2,1-b]furan-2-carbohydrazide 215c was treated with substituted aldehydes 2 in the presence of catalytic amount of acetic acid in absolute ethanol to give the hydrazone 219, which on treatment with chloroacetyl chloride in dioxane in the presence of triethylamine gave $\mathrm{N}$-(3chloro-2-(2-chloroquinolin-3-yl)-4-oxoazetidin-1-yl)naphtho[2,1-b]furan-2-carboxamide 
(Scheme 81). The synthesized compounds were screened for their antibacterial and antifungal activities. $^{144}$<smiles></smiles>

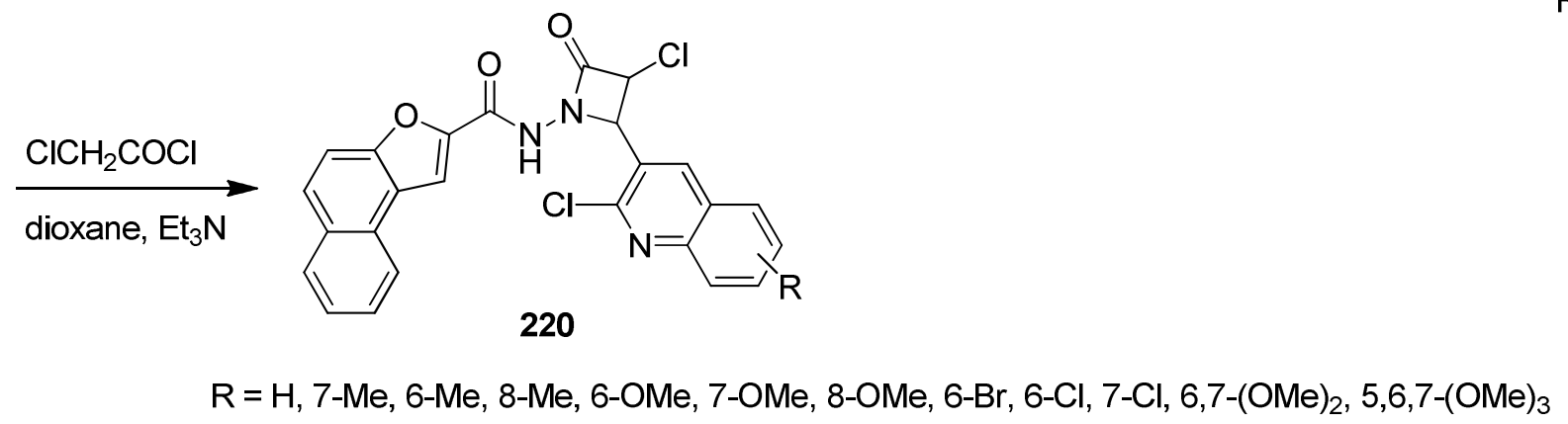

\section{Scheme 81}

Treatment of aldehyde 2 with aroyl hydrazides $\mathbf{2 1 5 d}$ in ethanol gave quinoline hydrazones 221. The latter compounds, on reaction with acetic anhydride at reflux, yielded 2-(2-chloro-3quinolyl)-5-aryl-2,3-dihydro-1,3,4-oxadiazoles 222 (Scheme 82). ${ }^{23}$

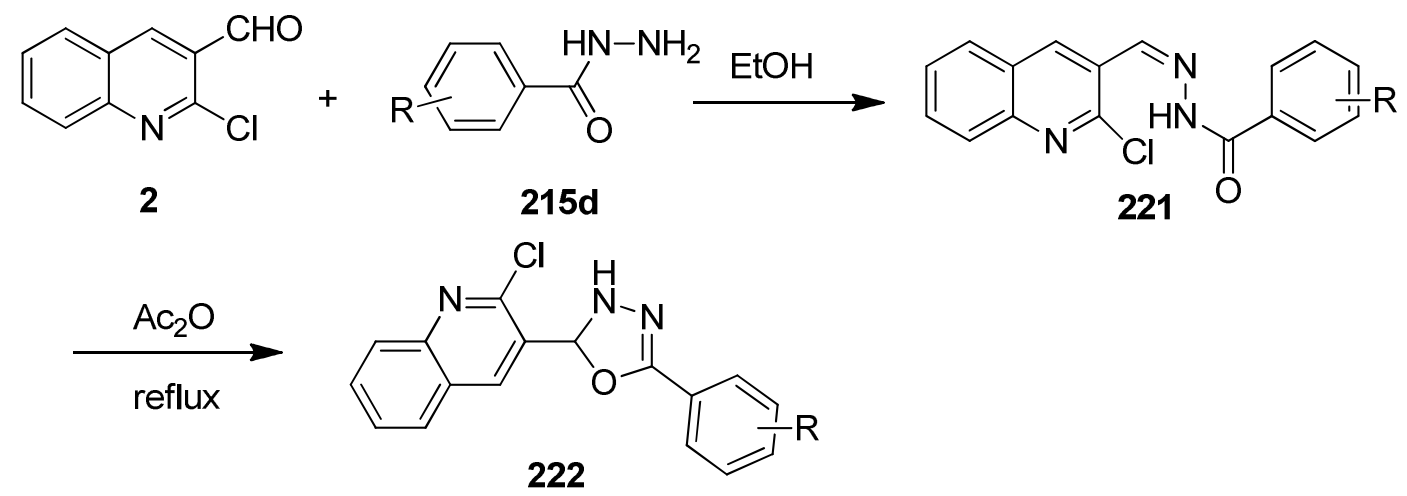

\section{Scheme 82}

$N^{\prime}$-[(2-Chloroquinolin-3-yl)methylene]-2-arylpropanehydrazide $\mathbf{2 2 4}$ was synthesized and evaluated for their anti-inflammatory activity from reaction of aldehyde $\mathbf{2}$ with arylpropanehydrazide 223 (Scheme 83). ${ }^{100,145}$ 
<smiles>[R]c1ccc(C(C)C(=O)N/N=C/c2cc3cc([R])ccc3nc2Cl)cc1</smiles>

$$
\mathrm{R}=\mathrm{H}, \mathrm{R}^{1}=\left(\mathrm{CH}_{3}\right)_{2} \mathrm{CHCH}_{2} ; \mathrm{R}=\mathrm{Me}, \mathrm{OMe}, \mathrm{Cl} ; \mathrm{R}^{1}=\mathrm{MeO}
$$

\section{Scheme 83}

Treatment of [1-(5-bromobenzofuran-2-yl)ethylidene]hydrazine 225 with aldehyde 2 in refluxed ethanol containing few drops of acetic acid, gave the corresponding Schiff base 226 (Scheme 84). ${ }^{146}$

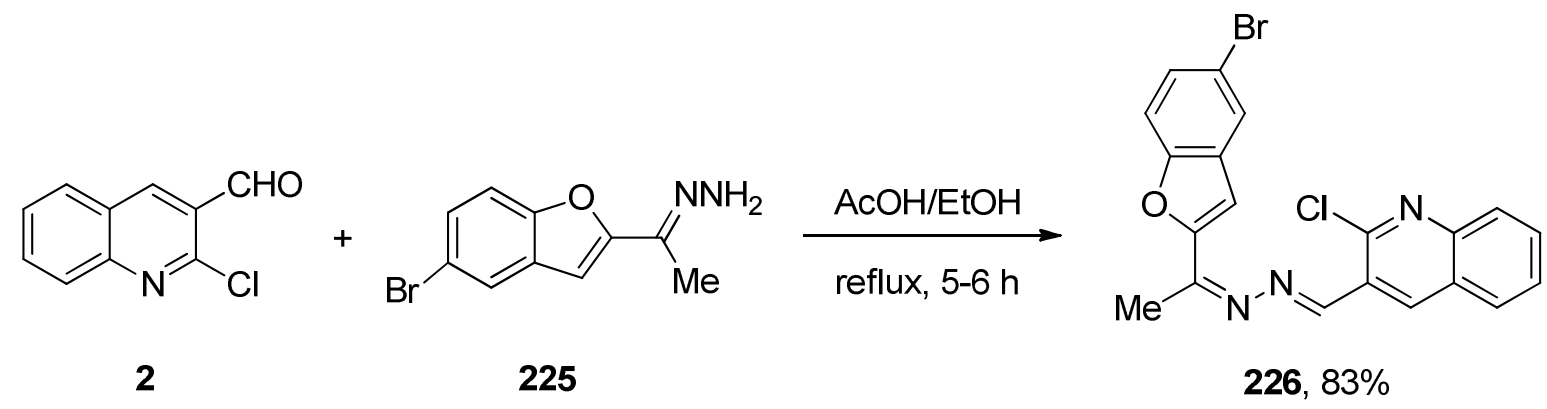

\section{Scheme 84}

Reaction of 3-chloro-2-hydrazono-1,2-dihydroquinoxaline 227 with aldehyde 2 under microwave irradiation yielded 3-chloro-2-((2-chloroquinolin-3-yl)methylene)hydrazono)-1,2dihydroquinoxaline 228 (Scheme 85). ${ }^{147}$

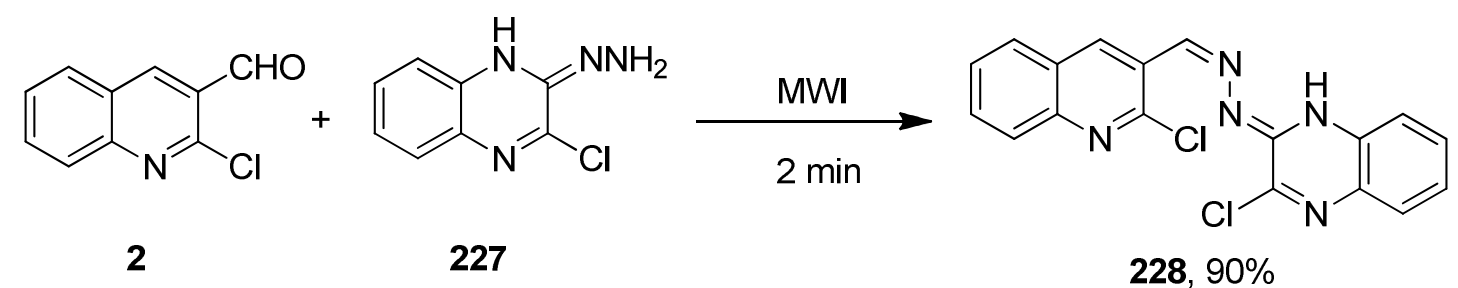

\section{Scheme 85}

\subsubsection{Reactions with amines and amides}

Condensation of aldehydes $\mathbf{2}$ with 2-aminophenol was reported either by traditional methods ${ }^{148,149}$ or under the influence of microwave irradiation using 1,8-diazabicycloundec-7ene-silica gel as a catalyst, ${ }^{150}$ to afford quinolino[2,3-b][1,5]benzoxazepine 229 in excellent 
yield. The later compound reacted with triethyl phosphite in the presence of $p$-toluenesulfonic acid ( $p$-TSA) under the influence of ultrasound irradiation under solvent-free conditions to give the $\alpha$-aminophosphonate 230 in high yield (Scheme 86). The synthesized compound showed antibacterial activity against gram-positive and gram-negative bacteria. ${ }^{148}$<smiles>CCOC(=O)C1C2=CC=C3N=C4Oc5ccccc5NC(P(=O)(OCC)OCC)C=C4C3=CC1=C2</smiles>

\section{Scheme 86}

Synthesis of 2-(2-chloroquinolin-3-yl)-3-phenylthiazolidin-4-ones 233 were reported either by DCC (dicyclohexylcarbodiimide) mediated three-component one-pot reaction of aldehyde 2 , amine, and mercaptoacetic acid $\mathbf{2 3 2}{ }^{151}$ or by cyclocondensation of mercaptoacetic acid $\mathbf{2 3 2}$ with Schiff bases $\mathbf{2 3 1}$ which in turn were prepared by the action of amines on aldehyde $\mathbf{2}$ (Scheme 87). ${ }^{152}$ The synthesized compounds were studied for interaction with calf thymus DNA by electronic spectra, viscosity measurements as well as thermal denaturation studies ${ }^{151}$ and screened for their antimicrobial activity against several microbes. ${ }^{152}$

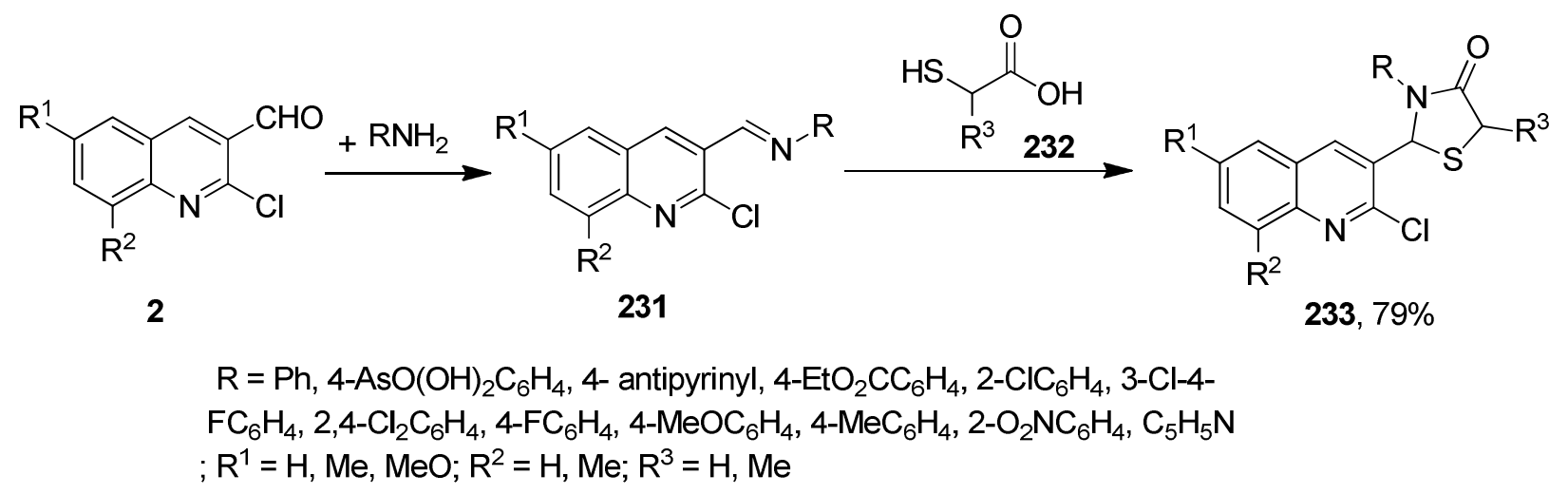

\section{Scheme 87}

The aldehydes 2 when reacted with aniline in DMF afford dibenzo[ $b, g][1,8]$ naphthyridines 234 (Scheme 88). ${ }^{153}$ 
<smiles>O=Cc1cc2c[R1]ccc2nc1Cl</smiles>

2<smiles>Nc1ccccc1</smiles><smiles>Oc1ccc2nc3nc4ccccc4cc3cc2c1</smiles>

234, $86-80 \%$

$\mathrm{R}=\mathrm{H}$; 5-Me;8-Me;8-Me, 6-Me; 6-OMe; 7-OMe; 8-OMe; 8-OMe, 5-OMe

\section{Scheme 88}

$N$-[(2-chloroquinolin-3-yl)methylene]prop-2-yn-1-amine 236 was synthesized in excellent yield by condensation of aldehyde $\mathbf{2}$ with prop-2-yn-1-amine $\mathbf{2 3 5}$ in either benzene or THF in the presence of magnesium sulfate (Scheme 89). ${ }^{154}$

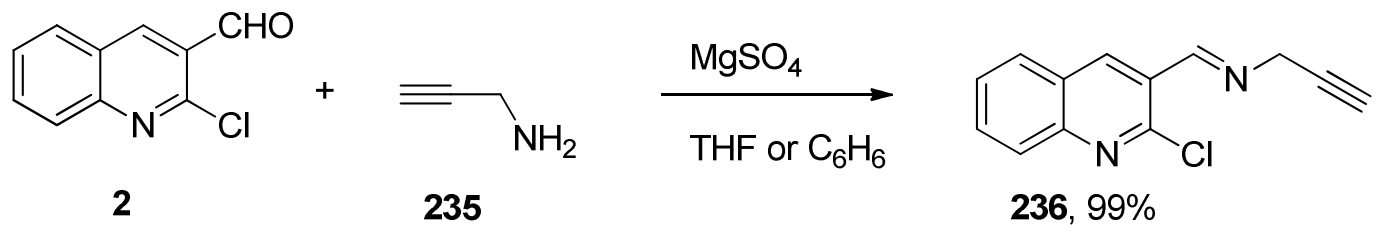

\section{Scheme 89}

2-(2-Chloroquinolin-3-yl)-10-ethyl-4-phenyl-10H-pyrido[2,3-b]carbazole 239 was obtained from cyclization of imine $\mathbf{2 3 8}$, derived from reaction of aldehyde $\mathbf{2}$ and 9-ethyl-9H-carbazol-3amine 237, with phenylacetylene in the presence of $\mathrm{CuI} / \mathrm{La}(\mathrm{OTf})_{3}$ in $[\mathrm{Bmim}]\left[\mathrm{BF}_{4}\right]$ followed by aromatization (Scheme 90). ${ }^{155}$<smiles>O=Cc1cc2ccccc2nc1Cl</smiles>

2

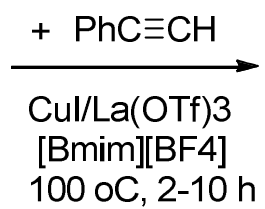<smiles>CCn1c2ccccc2c2cc(N)ccc21</smiles>

237<smiles>CCn1c2ccccc2c2cc(/N=C/c3cc4ccccc4nc3Cl)ccc21</smiles>

238<smiles>CCn1c2ccccc2c2cc3c(-c4ccccc4)cc(-c4cc5ccccc5nc4Cl)nc3cc21</smiles>

239, $65 \%$

[Bmim][BF4] = 1-butyl-3-methylimidazolium tetrafluoroborate

\section{Scheme 90}


Synthesis of $\alpha$-aminophosphonate $\mathbf{2 4 1}$ in excellent yields from reaction of imine $\mathbf{2 4 0}$, which obtained from reaction of aldehyde 2 and 3-fluoroaniline with triethyl phosphite in the presence of chlorotrimethylsilane (Scheme 91). ${ }^{156}$

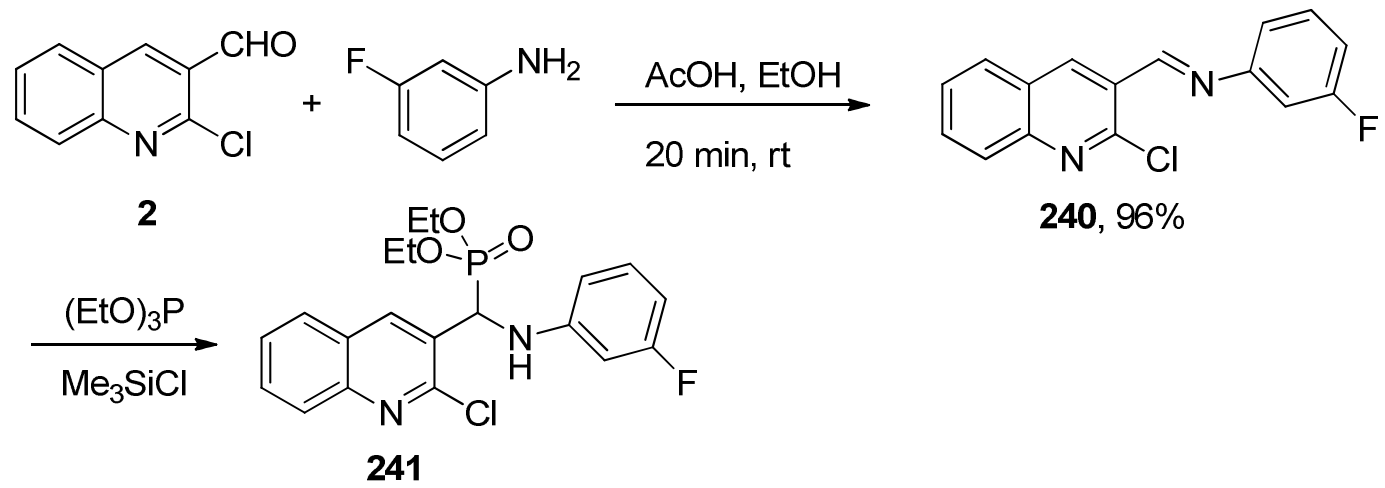

\section{Scheme 91}

3-Aryl-1H-[1,2,4]triazolo[4',3':2,3][1,2,4]triazepino[5,6-b]quinolines 243 were synthesized via heterocyclization of 5-aryl-3,4-diamino-1,2,4-triazoles $\mathbf{2 4 2}$ and aldehydes 2 in DMF in the presence of $p$-TsOH with either microwave irradiation or oil-bath heating at $80^{\circ} \mathrm{C}$ (Scheme 92). ${ }^{157}$

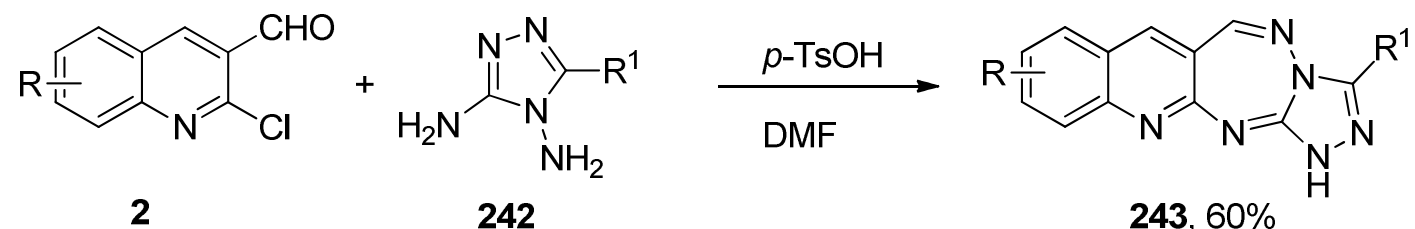

$$
\begin{aligned}
& \mathrm{R}=\mathrm{H}, 3-\mathrm{Me}, 4-\mathrm{OMe} ; \mathrm{R}^{1}=\mathrm{Ph}, 4-\mathrm{O}_{2} \mathrm{NC}_{6} \mathrm{H}_{4} \text {, 2- } \\
& \mathrm{ClC}_{6} \mathrm{H}_{4}
\end{aligned}
$$

\section{Scheme 92}

Stereoselective synthesis of $N^{1}, N^{2}$-bis[(2-chloroquinolin-3-yl)methylene]ethane-1,2-diamine 244 was reported by reaction of aldehyde 2 with ethylenediamine in ethanol at reflux temperature (Scheme 93). ${ }^{158}$

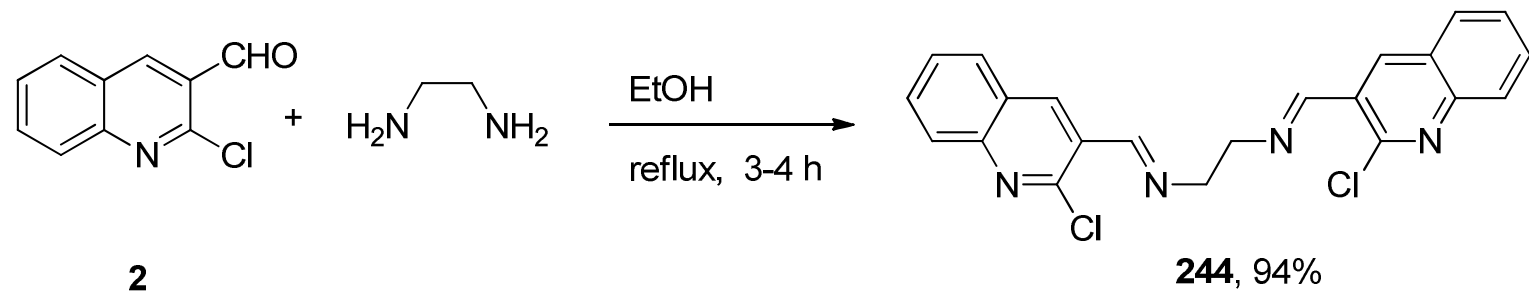

Scheme 93 
One-pot synthesis of 3-(1H-benzimidazol-2-yl)quinolin-2(1H)-one 245 was performed in $70 \%$ aqueous acetic acid in the presence of Amberlyst-15 (20\% wt./wt.) by the direct reaction of aldehyde 2 with $o$-phenylenediamine (Scheme 94). Antitumor studies against sixty different cancer cell lines showed the potential of these kinds of compound. ${ }^{159}$

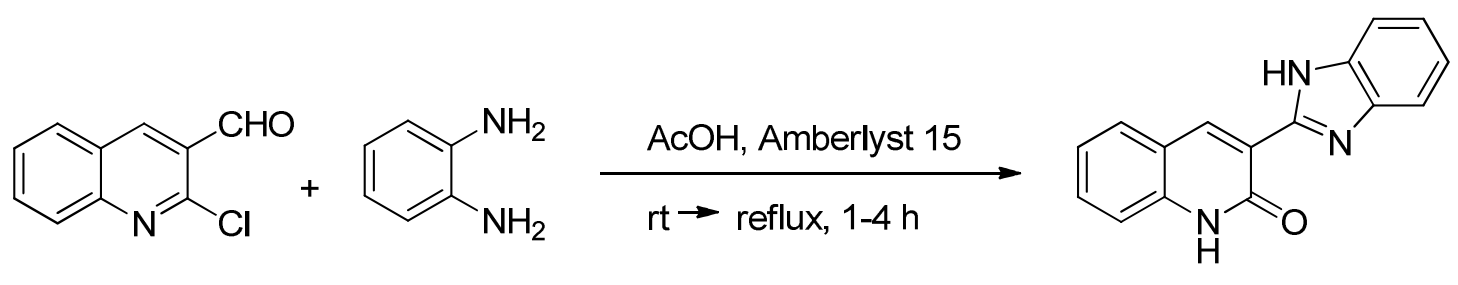

2

$245,84 \%$

\section{Scheme 94}

2-Phenyl-2H-[1,3]thiazino[6,5-b]quinolines 246 were synthesized in good to excellent yields by one pot reaction between aldehyde 2 and thiobenzamide using $p$-TsOH catalyst under microwave irradiation (Scheme 95). ${ }^{125-160}$

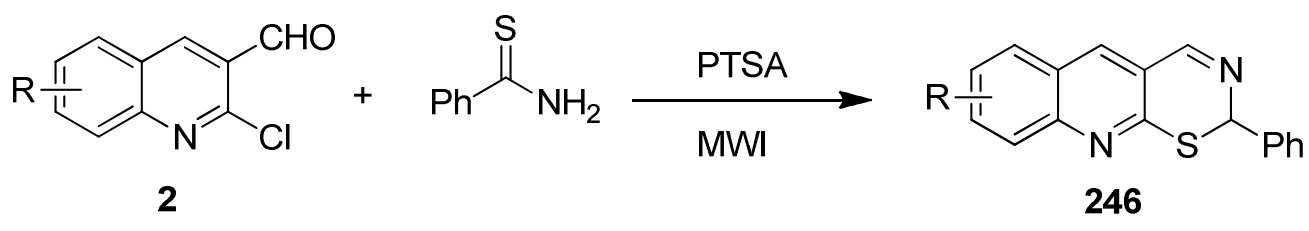

$$
\mathrm{R}=\mathrm{H}, 7-\mathrm{Me}, 8-\mathrm{Me}, 7-\mathrm{OMe}, 8-\mathrm{OMe}, 7-\mathrm{Br}, 7-\mathrm{Cl}
$$

\section{Scheme 95}

1H-Pyrazolo[3,4- $b$ ]quinoline-3-amines 249 were prepared by dehydration of 2-chloro-3quinolinecarbaldehyde oxime $\mathbf{2 4 7}$ with thionyl chloride followed by cyclization with hydrazine hydrate in ethanol. The fused pyrazole intermediates 249 were diazotized to give the diazonium salt 250. Subsequent coupling reactions took place with various heterocyclic compounds to obtain 251. ${ }^{161}$ Furthermore, 1-aryl-1H-pyrazolo[3,4- $b$ ]quinolin-3-amine $249(\mathrm{R}=\mathrm{H})$ were reacted with 1,3-thiazinan-4-one 252 and thiazolidin-4-one 254 to give Schiff base adducts 253 and 255, respectively (Scheme 96). The antimicrobial activity was evaluated for most of the prepared compounds. ${ }^{162}$ 

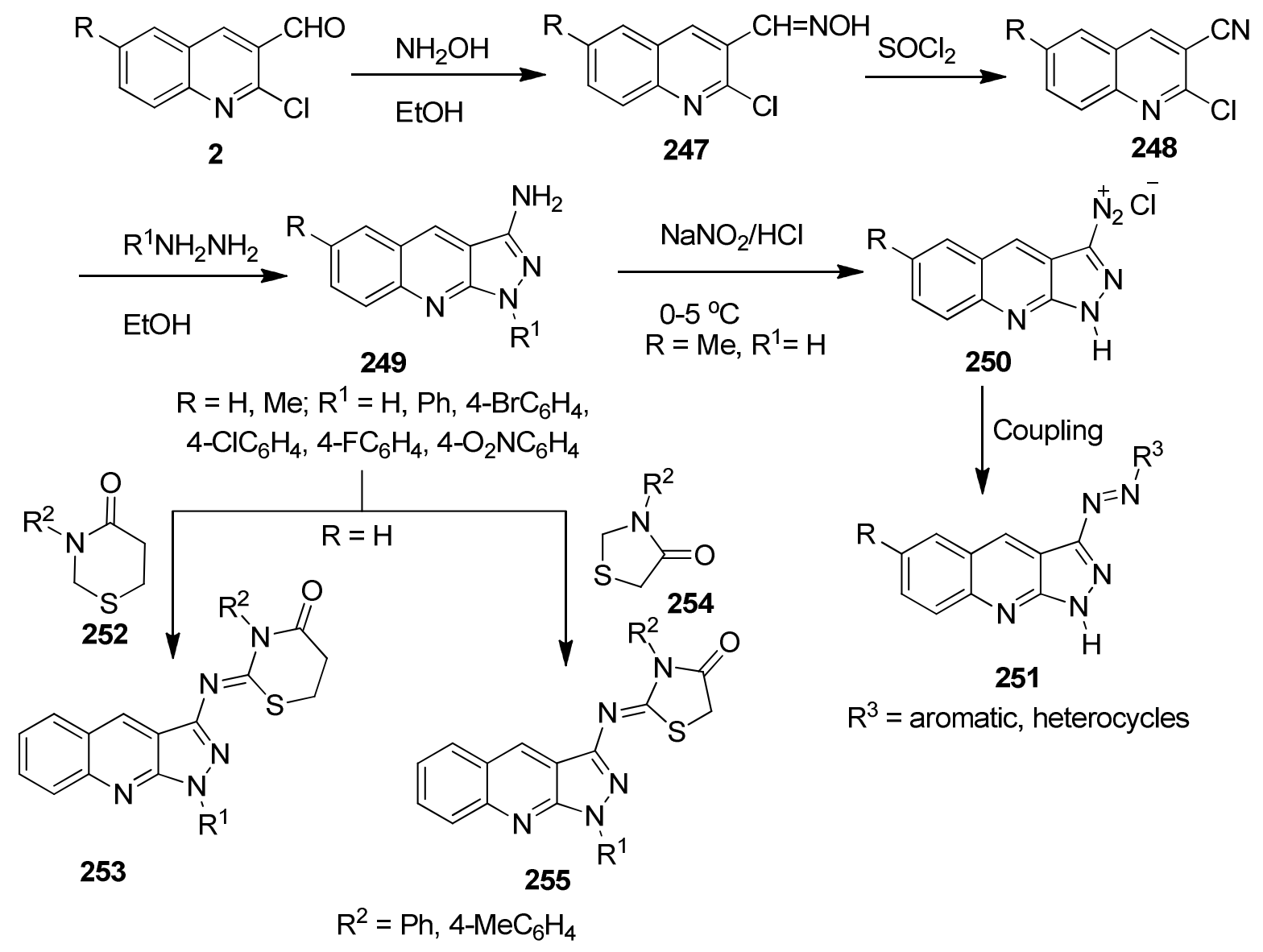

\section{Scheme 96}

Reaction of aldehyde 2, 1-vinylpyrrolidin-2-one 256, and substituted aniline at room temperature in a water-acetonitrile mixture $(1: 1)$ in the presence of $5 \mathrm{~mol} \%$ ceric ammonium nitrate $(\mathrm{CAN})$ for $\sim 50 \mathrm{~min}$. afforded tetrahydroquinolines 257 in good yields as single regioisomers and diastereoisomers. Subsequently, the tetrahydroquinolines 257 were oxidized to the corresponding 2'-chloro-2,3'-biquinoline 258 by reaction with 2.5 equivalent of CAN in acetonitrile at $0{ }^{\circ} \mathrm{C}$ (Schemes 97$) .{ }^{163}$ 


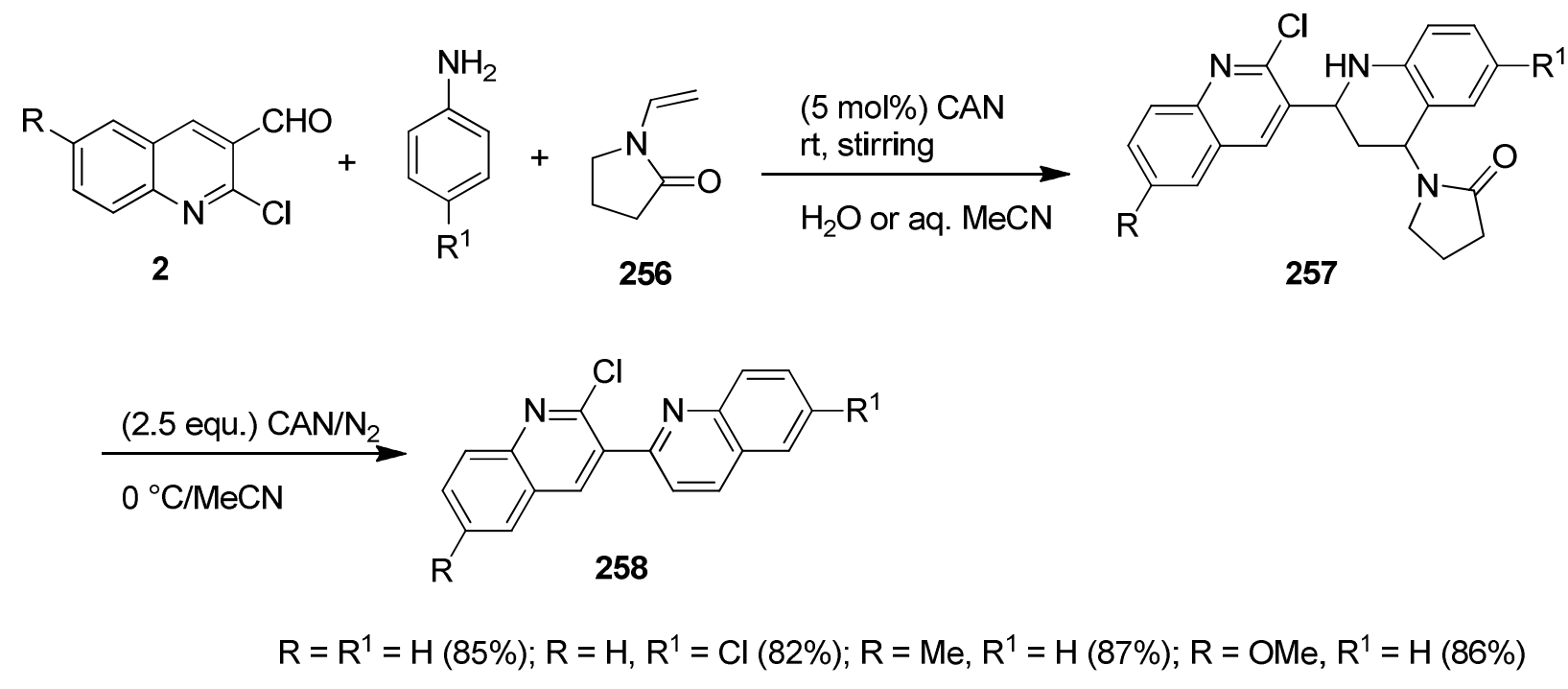

\section{Scheme 97}

The condensation of aldehyde 2 with various derivatives of 4-amino-5-aryl-4H-1,2,4triazole-3-thiol 259 either by using microwave irradiated in the presence of Montmorillonite K10 clay in $\mathrm{DMSO}^{164}$ or by traditional method ${ }^{89,165}$ was reported to give 3-aryl-[1,2,4]triazolo[ $\left[3^{\prime}, 4^{\prime}: 2,3\right][1,3,4]$ thiadiazepino[7,6- $\left.b\right]$ quinolines 260 . The base catalyzed facile intramolecular rearrangement of $\mathbf{2 6 0}$ to $s$-triazolothiazinoquinolines $\mathbf{2 6 1}$ involving $N-N$ bond scission (Scheme 98).

The condensation of aldehyde 55 with 1-amino-2-mercapto-5-aryl-1,3,4-triazole 259 either by microwave irradiation using basic alumina as solid support or by stirring in DMF to give 3substituted-6-(tetrazolo[1,5- $a$ ]quinolin-4-yl)-5,6-dihydro-[1,2,4]triazolo[3,4- $b]$-[1,3,4]thiadiazole 262 (Scheme 98). ${ }^{166}$ Compounds 261 and $\mathbf{2 6 2}$ were screened for their antibacterial and antifungal activity. ${ }^{165,166}$

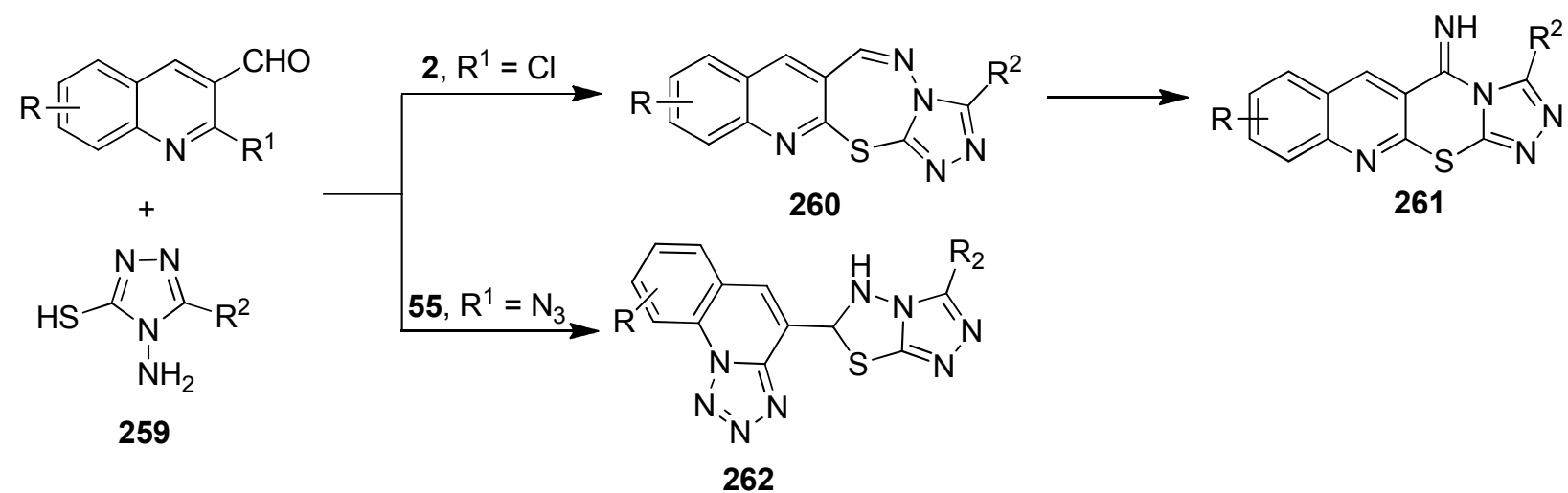

$$
\begin{aligned}
& \mathrm{R}=\mathrm{H}, 6-\mathrm{F}, 8-\mathrm{Cl}, 6-\mathrm{Br}, 6-\mathrm{Me}, 6-\mathrm{MeO} ; \mathrm{R}^{2}=\mathrm{Me}, \mathrm{Ph}, 4- \\
& \mathrm{ClC}_{6} \mathrm{H}_{4}, 4-\mathrm{MeOC}_{6} \mathrm{H}_{4}, \mathrm{ArNHCH}_{2}
\end{aligned}
$$

\section{Scheme 98}


Condensation of aldehyde 2 with ethyl 2-aminoacetate hydrochloride gave imine 263, which on cyclization in either sulfuric acid or Dowtherm A, furnished 5-chlorobenzo[c][2,7]naphthyridin-1-ol 264 (Scheme 99). An improved yield was observed in Dowtherm A. ${ }^{167}$

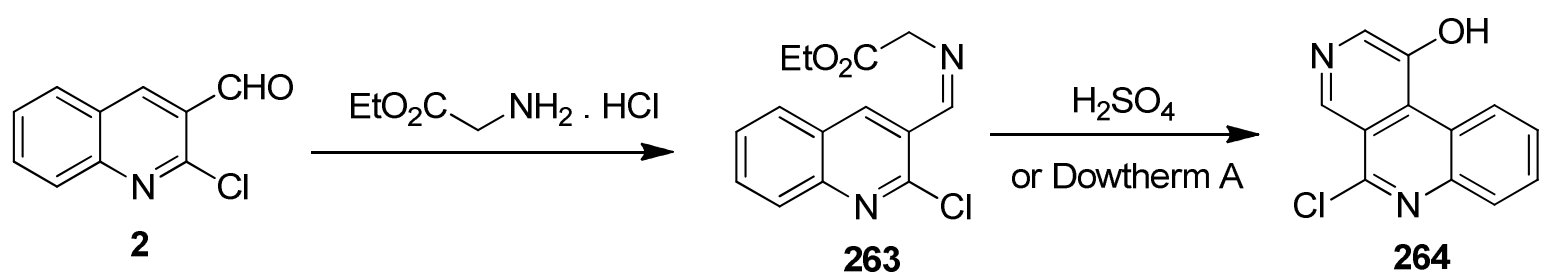

\section{Scheme 99}

The reaction of aldehyde 2 with sarcosine 265 in refluxing xylene gave 2-methyl-5,9bdihydro-1H-pyrrolo[3,4-c]quinolin-4(2H)-ones $\mathbf{2 6 9}$ in acceptable yields via 1,5-electrocyclisation reaction accompanied by hydrolysis of the chlorine function under the applied reaction conditions in the presence of the water formed in the first step. The intermediate of azomethine ylides 266 were shown by trapping the proposed dipoles with $N$-phenylmaleimide to give the two isomeric cycloadducts $\mathbf{2 6 8 a}$ and $\mathbf{2 6 8 b}$ (endo-exo ratio1:1) in quantitative yield (Scheme 100). ${ }^{20-168}$<smiles>[R1]c1cc([R2])c2nc(Cl)c(C=O)cc2c1</smiles><smiles>[R]c1cc([R2])c2nc(Cl)c(CCCCC)cc2c1</smiles><smiles>[R]c1cc([R2])c2c(c1)C1CN(C)C=C1C(Cl)=N2</smiles><smiles>[R12]c1cc([R])c2[nH]c(=O)c([C@@H]3[C@H]4C(=O)N(c5ccccc5)C(=O)[C@@H]4CN3C)cc2c1</smiles><smiles>[R1]c1cc([R])c2[nH]c(=O)c([C@@H]3C4C(=O)N(c5ccccc5)C(=O)C4CN3C)cc2c1</smiles><smiles>[R]c1cc([R])c2c(c1)C1CN(C)C=C1C(=O)N2</smiles>

$$
\begin{aligned}
& \mathrm{R}^{1}=\mathrm{R}^{2}=\mathrm{H}(47.5 \%) \\
& \mathrm{R}^{1}=\mathrm{OMe}, \mathrm{R}^{2}=\mathrm{H}(49.5 \%) \\
& \mathrm{R}^{1}=\mathrm{H}, \mathrm{R}^{2}=\mathrm{Me}(47.5 \%)
\end{aligned}
$$
a, $R^{1}=R^{2}=H(45 \%)$
b, $R^{1}=\mathrm{OMe}, \mathrm{R}^{2}=\mathrm{H}(53 \%)$
c, $R^{1}=H, R^{2}=\operatorname{Me}(52 \%)$

Scheme 100 
3.4.4 Miscellaneous reactions. Aldehyde 2 was transformed into 2-chloroquinoline-3carbonitrile 270 by using either propylphosphonic anhydride or hydroxylamine ${ }^{169}$ (98\%) or iodine and aqueous ammonia in THF at room temperature (82\%) (Scheme 101). ${ }^{170}$

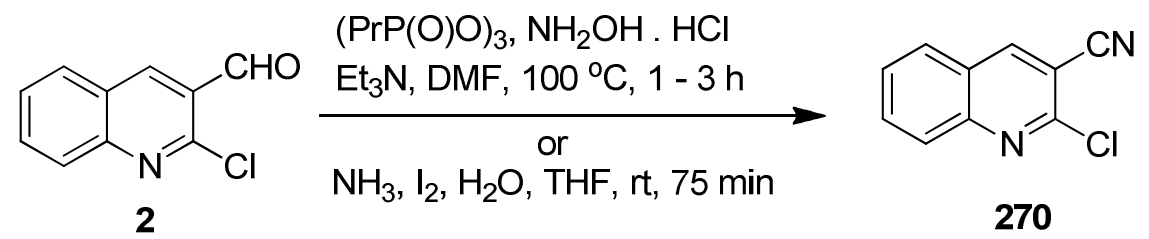

\section{Scheme 101}

The aldehyde 2 was reacted with Grignard reagent $(\mathrm{MeMgBr}, 98 \%)$ followed by oxidation by $\mathrm{MnO}_{2}(80 \%)$ to give the methyl ketone. Finkelstein reaction on the latter compound yielded the iodo derivative $271(80 \%)$. Action of TBSOTf with $\mathrm{Et}_{3} \mathrm{~N}$ on 271 gave the $O$-TBS protected derivative 272 (77\%), which underwent efficient Sonogashira reaction with several alkynes: 1hexyne (273a, 70\%), phenylacetylene (273b, 60\%), tetrahydro-2-(2-propynyloxy)-2H-pyran (273c, 70\%), 3,3-diethoxy-1-propyne (273d, 72\%). The $\mathrm{Rh}(\mathrm{I})$-catalyzed cyclization produced the corresponding 1,3-disubstituted acridines 274a (60\%), 274b (50\%), 274c (60\%), 274d (40\%) (Scheme 102). ${ }^{171}$

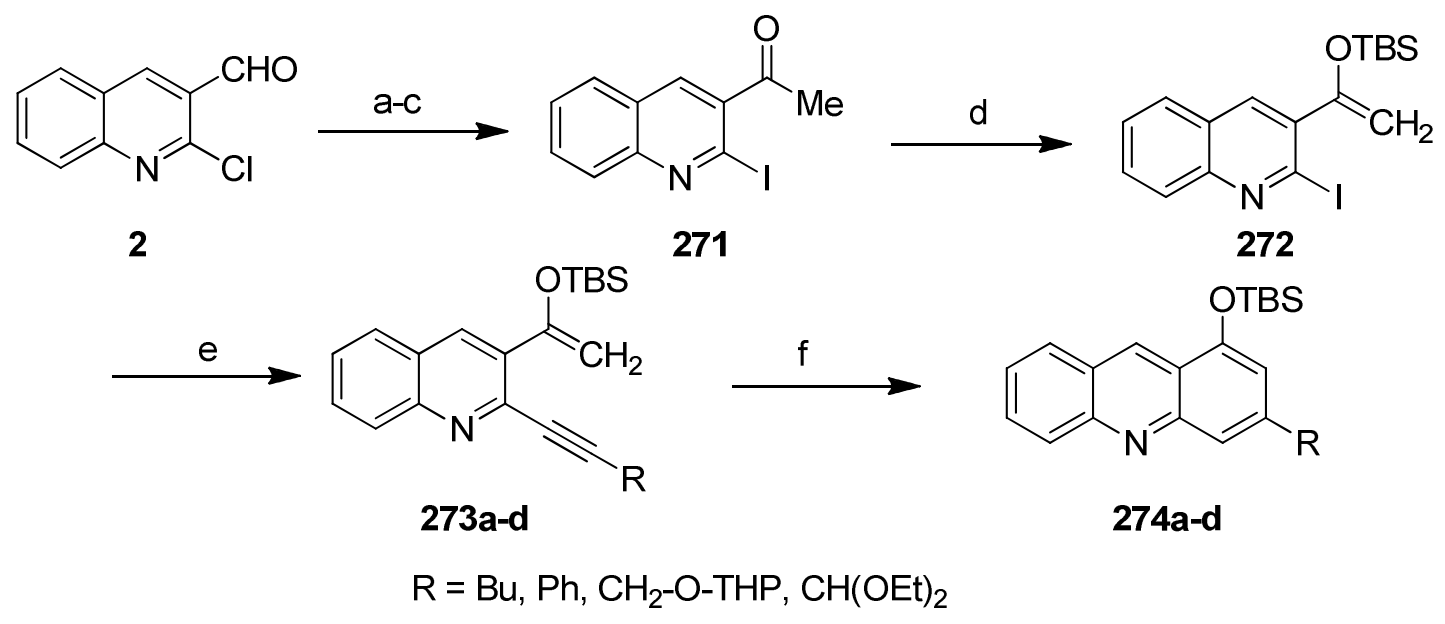

(a) 3 equiv MeMgBr, THF, $40{ }^{\circ} \mathrm{C}, 98 \%$; (b) 10 equiv $\mathrm{MnO}_{2}$, toluene, $80^{\circ} \mathrm{C}$, quant.; (c) $\mathrm{Nal}, \mathrm{CH}_{3} \mathrm{CN}$, 0.5 equiv $\mathrm{HCl} 4 \mathrm{~N}$, reflux, 80-98\%; (d) 2.2 equiv TBSOTf, 3 equiv $\mathrm{Et}_{3} \mathrm{~N}, \mathrm{CH}_{2} \mathrm{Cl}_{2}, 77 \%$; (e) 1- alkyne, 0.07 equiv $\mathrm{PdCl}_{2}\left(\mathrm{PPh}_{3}\right)_{2}, 0.3$ equiv Cul, 1.5 equiv $\mathrm{Et}_{3} \mathrm{~N}$, toluene, rt; (f) $10 \mathrm{~mol} \%\left[\mathrm{Rh}(\mathrm{CO})_{2} \mathrm{Cl}\right]_{2}$, toluene, $2-4 \mathrm{~h}, 120^{\circ} \mathrm{C}$.

\section{Scheme 102}


Similarly, the reaction of 1-(2-(pyridin-2-ylethynyl)quinolin-3-yl)ethanone $\mathbf{2 7 5}$ with pyrrolidine in refluxed dichloromethane in the presence of powdered molecular sieves gave 3(pyridin-2-yl)-1-(pyrrolidin-1-yl)acridine 276 via the enamine synthesis and the aminobenzannulation step took place subsequently (Scheme 103). ${ }^{172}$<smiles>CC(=O)c1cc2ccccc2nc1C#Cc1ccccn1</smiles>

\section{Scheme 103}

2,4,5-Trisubstituted imidazoles 278 were synthesized from reaction between benzil $\mathbf{2 7 7}$, aldehydes $\mathbf{2}$ and excess of ammonium acetate either by traditional method using refluxed acetic acid, ${ }^{21}$ or by solvent-free microwave irradiation. Similarly, 1,2,4,5-tetrasubstituted imidazoles 279a,b were also obtained in high yields within few minutes by the four-component condensation of benzil, the aldehyde $\mathbf{2}$, a primary amine and ammonium acetate under microwave irradiation (Scheme 104). ${ }^{173}$

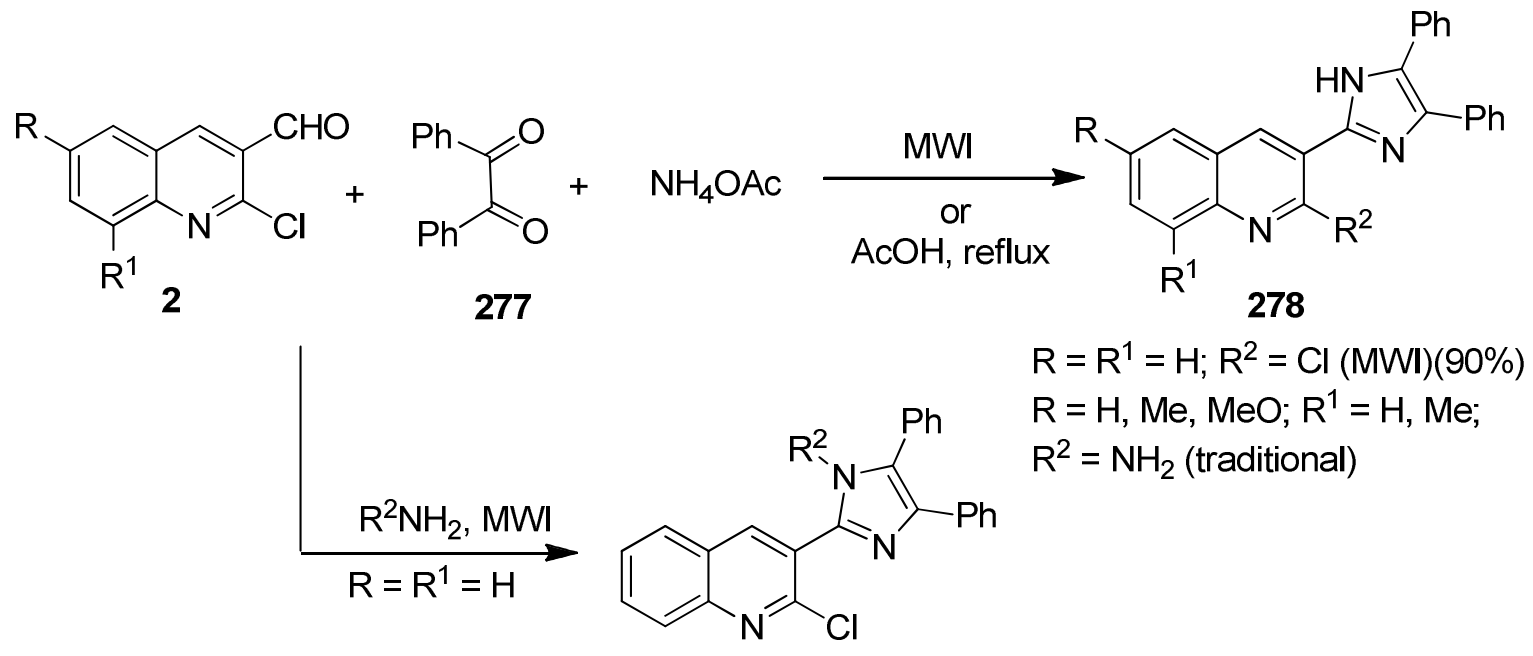

279a, $R^{2}=P h(89 \%)$

b, $R^{2}=B z(88 \%)$

\section{Scheme 104}


Julia olefination between aldehyde 2 and $\alpha$-halomethyl sulfones 280a,b in THF in the presence of lithium bis(trimethylsilyl)amide afforded 2-chloro-3-(2-halovinyl)quinoline 281a,b in good yields with high $E / Z$ stereoselectivities (Scheme 105). ${ }^{174}$

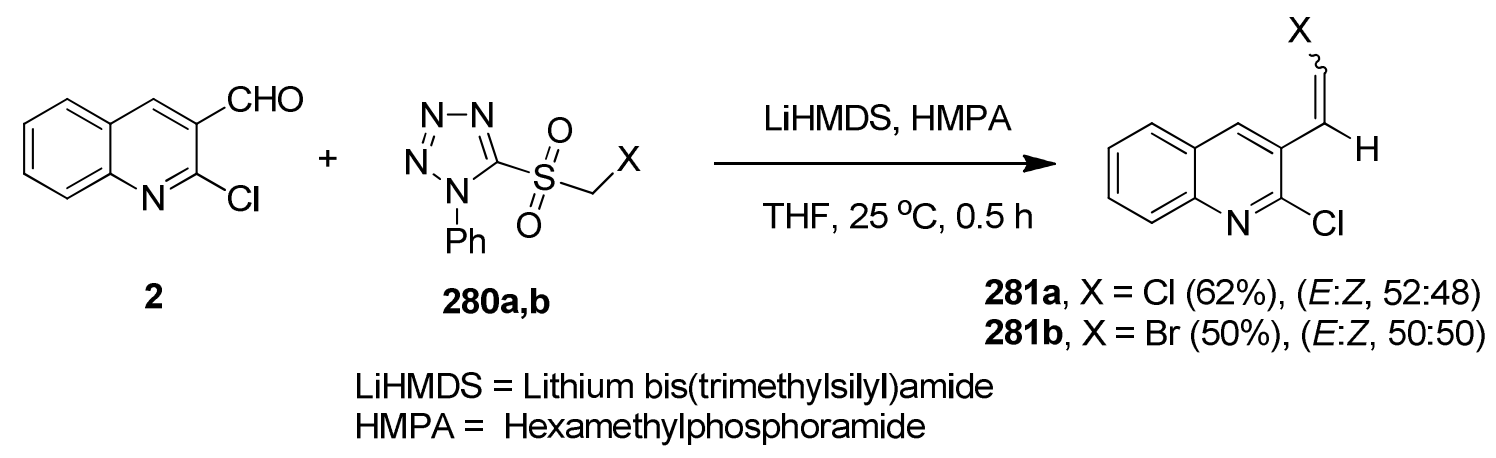

\section{Scheme 105}

meso-Tetrakis(2-chloroquinolin-3-yl)porphyrins $\mathbf{2 8 3}$ were synthesized from reaction of aldehyde 2 with pyrrole 282 in 1:1 ratio in propionic acid at $140{ }^{\circ} \mathrm{C}$ for $4 \mathrm{~h}$ (Scheme 106). ${ }^{175}$

2

282

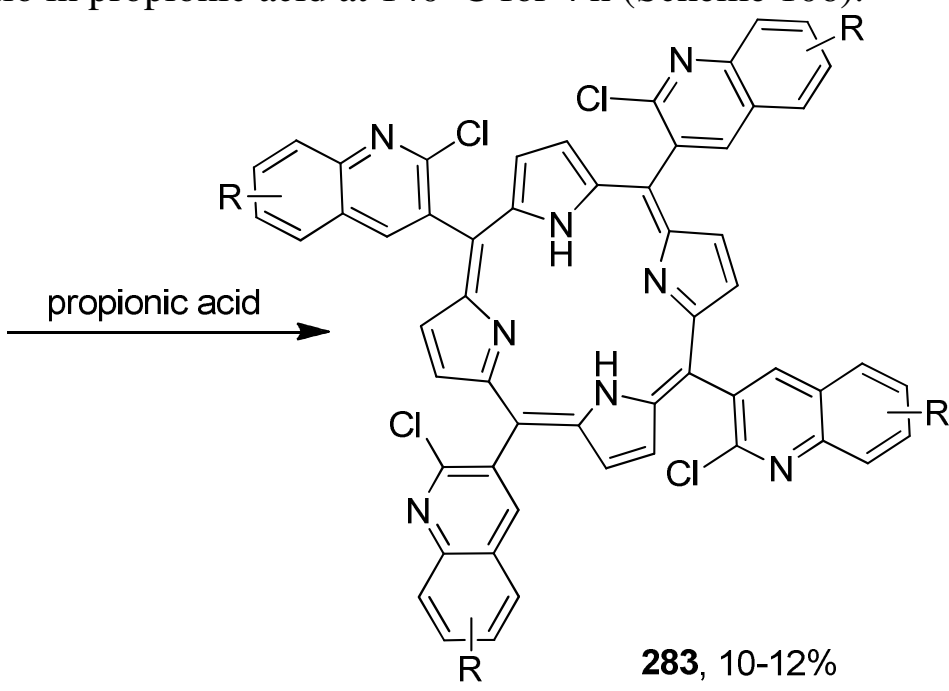

$\mathrm{R}=6-\mathrm{Me}, 6-\mathrm{OMe}, 7-\mathrm{OMe}$

\section{Scheme 106}

3-[(4-(Dimethylamino)phenylamino)methyl]-5,6,7-trimethoxyquinolin-2(1H)-one $\mathbf{2 8 4}$ was prepared from reaction between 5,6,7-trimethoxy-2-oxo-1,2-dihydroquinoline-3-carbaldehyde via reductive amination with $N^{1}, N^{1}$-dimethylbenzene-1,4-diamine in 1,2-dichloroethane containing $\mathrm{NaBH}(\mathrm{OAc})_{3}$. $^{176}$ 
<smiles>COc1cc2[nH]c(=O)c(CNc3ccc(N(C)C)cc3)cc2c(OC)c1OC</smiles>

284

The Ugi four-component reaction of aldehyde 2, 2-halo-5-nitrobenzoic acid, (4-methoxyphenyl)methanamine, and isonitrile resulted in formation of the classical U-4CC product, followed by intramolecular cyclization to produce 3-oxoisoindoline adduct in $73 \%$ yield (Scheme 107). ${ }^{177}$

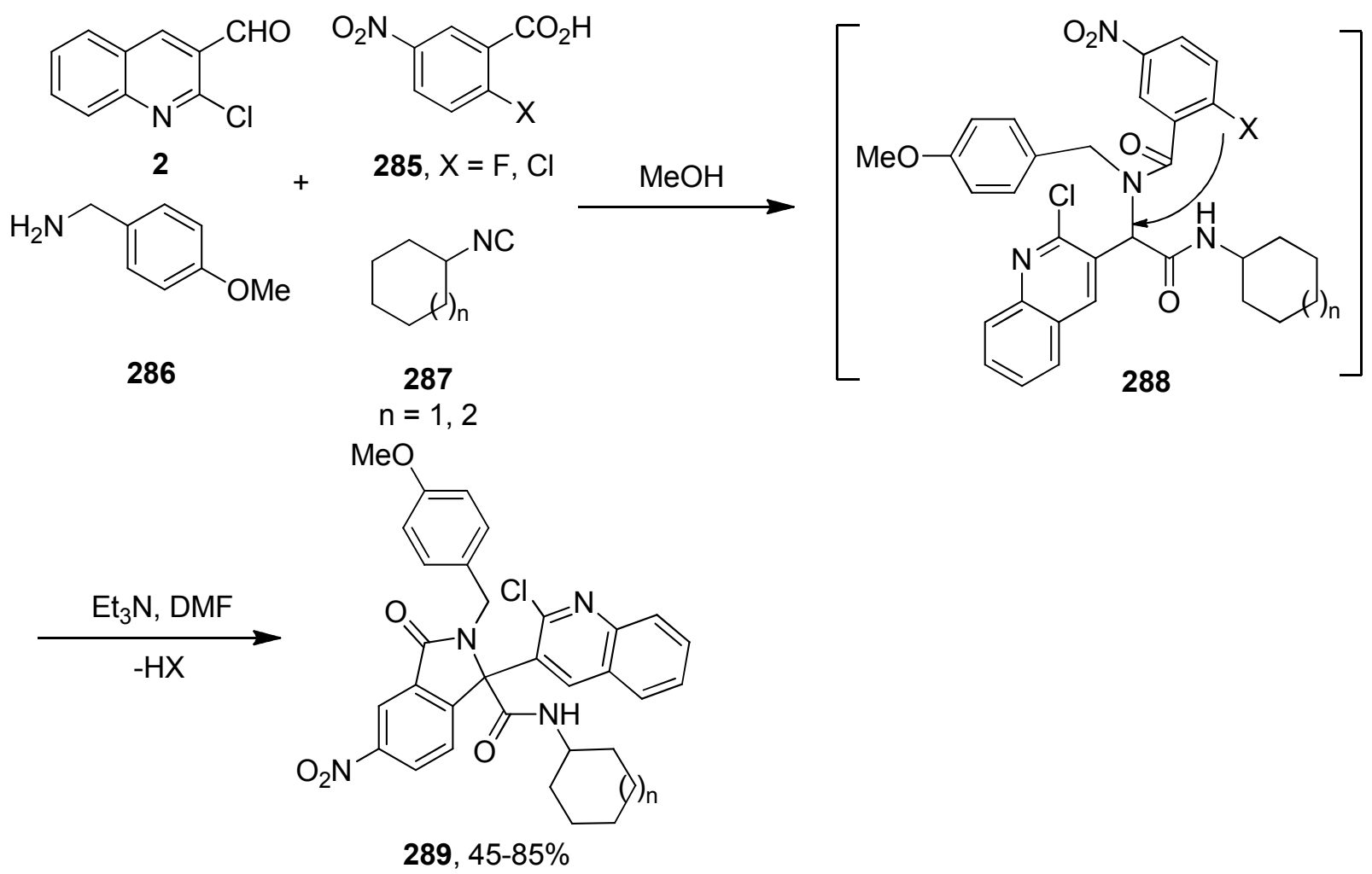

\section{Scheme 107}

\section{Conclusions}

2-Chloroquinoline-3-carbaldehydes are easily available and have high chemical reactivity due to the presence of both chloro and aldehyde groups. This survey is attempted to summarize the synthetic methods and reactions of 2-chloroquinoline-3-carbaldehydes during the last twelve 
years. We will publish the literature survey of the chemistry of 2-chloroquinoline-3carbaldehydes from the first to the end of 1999 in a separate review article in the near future.

\section{References}

1. Selvi, S. T.; Nadaraj, V.; Mohan, S.; Sasi, R. Hema, M. Bioorg. Med. Chem. 2006, 14, 3896 and references cited therein.

2. Pokalwar, R. U.; Hangarge, R. V.; Maske, P. V.; Shingare, M. S. Arkivoc 2006, (xi), 196 and references cited therein.

3. (a) Khidre, R. E.; Abu-Hashem, A. A.; El-Shazly, M. Eur. J. Med. Chem. 2011, 46, 5057.

(b) Kidwai, M.; Saxena, S.; Khalilur Rahman Khan, M.; Thukral, S. S. Eur. J. Med. Chem. 2005, 40, 816 .

4. Charris, J. E.; Lobo, G. M.; Camacho, J.; Ferrer, R.; Barazarte, A.; Dominguez, J. N.; Gamboa, N.; Rodrigues, J. R.; Angel, J. E. Lett. Drug Design. Discov. 2007, 4, 49.

5. Kaur, K.; Jain, M.; Reddy, R. P.; Jain, R. Eur. J. Med. Chem. 2010, 45, 3245.

6. Khidre, R. E.; Abdel-Wahab, B. F.; Badria, F. A.-R. Lett. Drug Design Discov. 2011, 8, 640.

7. Chen, Y.-L.; Chen, I.-L.; Lu, C.-M.; Tzeng, C.-C.; Tsao, L.-T.; Wang, J.-P. Bioorg. Med. Chem. 2004, 12, 387.

8. Bawa, S.; Kumar, S. Indian J. Chem. 2009, 48B, 142.

9. Abdou, W. M.; Khidre, R. E.; Shaddy, A. A. J. Heterocycl. Chem. 2011, DOI 10.1002/jhet.968.

10. Abdou, W. M.; Khidre, R. E. Kamel, A. A. Arch. Pharm. Chem. Life Sci. 2012, 345, 123.

11. (a) P. G. Goekjian, PCT Int. Appl. WO 2009090623, 2009;

http://worldwide.espacenet.com/numberSearch?locale=en_EP. (b) Patin, A.; Belmont, P. Synthesis 2005, 14, 2400.

12. Kouznetsov, V. V.; Méndez, L. Y. V.; Leal, S. M.; Cruz, U. M.; Coronado, C. A.; Gómez, C. M. M.; Bohórquez, A. R. R. Rivero, P. E. Lett. Drug Design Discov. 2007, 4, 293.

13. (a) Abdel-Wahab, B. F.; Khidre, R. E.; Farahat, A. A. Arkivoc 2011, (i), 196. (b) Dawood, K. M.; Elwan, N. M.; Abdel-Wahab, B. F. Arkivoc 2011, (i), 111. (c) Dawood, K. M.; Abdel-Wahab, B. F. Arkivoc 2010, (i), 333.

14. Ramesh, E.; Sree Vidhya, T. K.; Raghunathan, R. Tetrahedron Lett. 2008, 49, 2810.

15. Kidwai, M.; Negi, N. Monatsh. Chem. 1997, 128, 85.

16. Cohen, B. W.; Polyansky, D. E.; Zong, R.; Zhou, H.; Ouk, T.; Cabelli, D. E.; Thummel, R. P.; Fujita, E. Inorganic Chem. 2010, 49, 8034.

17. Rajakumar, P.; Raja, R. Tetrahedron Lett. 2010, 51, 4365.

18. Venkatesan, P.; Sumathi, S. J. Heterocycl. Chem. 2010, 47, 81.

19. Srivastava, A.; Singh, R. M. Indian J. Chem. 2005, 44B, 1868.

20. Nyerges, M.; Pinter, A.; Viranyi, A.; Gabor, B.; Toke, L. Tetrahedron 2005, 61, 8199. 
21. Krishnan, V. S. H.; Dubey, P. K.; Rao, S. S.; Aparna, V. Indian J. Heterocycl. Chem. 2003, 13,11 .

22. Krishnan, V. S. H.; Dubey, P. K.; Rao, S. S.; Reddy, P. V. P. Indian J. Heterocycl. Chem. 2003, 13, 5 .

23. Dubey, P. K.; Rao S. S.; Reddy, P. V. P. Indian Heterocycl. Commun. 2003, 9, 411.

24. Mogilaiah, K.; Reddy, N. V.; Rao, R. B. Indian J. Heterocycl. Chem. 2002, 11, 253.

25. Ali, M. M.; Sana, S.; Tasneem, R. K. C.; Saiprakash, P. K. Synth. Commun. 2002, 32, 1351.

26. Cao, H. T.; Grée, R. Tetrahedron Lett. 2009, 50, 1493.

27. Baruah, B.; Bhuyan, P. J. Tetrahedron 2009, 65, 7099.

28. Chandra, A.; Singh, B.; Khanna, R. S.; Singh, R. M. J. Org. Chem. 2009, 74, 5664.

29. Verma, A. K.; Rustagi, V.; Aggarwal, T.; Singh, A. P. J. Org. Chem. 2010, 75, 7691.

30. Verma, A. K.; Aggarwal, T.; Rustagi, V.; Larock, R. C. Chem. Commun. 2010, 46, 4064.

31. Chandra, A.; Singh, B.; Upadhyay, S.; Singh, R. M. Tetrahedron 2008, 64, 11680.

32. Rajakumar, P.; Raja, R.; Selvam, S.; Rengasamy, R.; S. Nagaraj, Bioorg. Med. Chem. Lett. 2009, 19, 3466.

33. Mandhane, P. G.; Joshi, R. S.; Mahajan, P. S.; Nikam, M. D.; Nagargoje, D. R.; Gill, C. H. Arabian J. Chem. 2011, doi:10.1016/j.arabjc.2011.01.025.

34. Rajakumar, P.; Raja, R. Tetrahedron Lett. 2010, 51, 4365.

35. Kalita, P. K.; Baruah, B.; Bhuyan, P. J. Tetrahedron Lett. 2006, 47, 7779.

36. Nandeshwarappa, B. P.; Kumar, D. B. A.; Naik, H. S. B.; Mahadevan, K. M. Phosphorus, Sulfur, Silicon, Relat Elem. 2006, 181, 1997.

37. Prakash Naik, H. R.; Bhojya Naik, H. S.; Ravikumar Naik, T. R.; Raghavendra, M.; Aravinda, T.; Lamani, D. S. Phosphorus, Sulfur, Silicon, Relat Elem. 2009, 184, 460.

38. Srivastava, A.; Chandra, A.; Singh, R. M. Indian J. Chem. 2007, 46B, 303.

39. Kiran, B. M.; Nandeshwarappa, B. P.; Prakash, G. K.; Vaidya, V. P.; Mahadevan, K. M. Phosphorus, Sulfur, Silicon, Relat. Elem. 2007, 182, 993.

40. Raghavendra, M.; Bhojya Naik, H. S.; Sherigara, B. S. Phosphorus, Sulfur, Silicon, Relat. Elem. 2008, 183, 1501.

41. Basavaraju, B.; Bhojyanaik, H. S.; Prabhakara, M. C. Molbank 2006, M518.

42. Kalluraya, B.; Nayak, J.; Adhikari, A.; Sujith, K. V.; Shetty, N. S.; Winter, M. Phosphorus, Sulfur, Silicon, Relat. Elem. 2008, 183, 1870.

43. Mali, J. R.; Pratap, U. R.; Jawale, D. V.; Mane, R. A. Tetrahedron Lett. 2010, 51, 3980.

44. Prakash, G. A.; Kumar, N. S.; Rajendran, S. P. Asian J. Chem. 2002, 14, 1303.

45. Liu, Z.-C.; Wang, B.-D.; Li, B.; Wang, Q.; Yang, Z.-Y.; Li, T.-R.; Li, Y. Eur. J. Med. Chem. 2010, 45, 5353.

46. Ibrahim, N. M.; Yosef, H. A. A.; Mahran, M. R. H. J. Chem. Res. 2009, 4, 220.

47. Sonar, S. S.; Sadaphal, S. A.; Pokalwar, R. U.; Shingate, B. B.; Shingare, M. S. J. Heterocycl. Chem. 2010, 47, 441. 
48. Bekhit, A. A.; El-Sayed, O. A.; Aboulmagd, E.; Park, J. Y. Eur. J. Med. Chem. 2004, 39, 249.

49. Kidwai, M.; Bhushan, K. R.; Sapra, P.; Saxena, R. K.; Gupta, R. Bioorg. Med. Chem. 2000, $8,69$.

50. Li, P.; Majireck, M. M.; Korboukh, I.; Weinreb, S. M. Tetrahedron Lett. 2008, 49, 3162.

51. Boulcina, R.; Belfaitah, A.; Rhouati, S.; Debache, A. J. Soc. Algeri. Chim. 2008, $18,61$.

52. Rodrigues Jr., M. T.; Gomes, J. C.; Smith, J.; Coelho, F. Tetrahedron Lett. 2010, 51, 4988.

53. Zhong, W.; Lin, F.; Chen, R.; Su, W. Synthesis 2009, 14, 2333.

54. Kohn, L. K.; Pavam, C. H.; Veronese, D.; Coelho, F.; De Carvalho, J. E.; Almeida, W. P. Eur. J. Med. Chem. 2006, 41, 738.

55. Coelho, F.; Veronese, D.; Pavam, C. H.; de Paula, V. I.; Buffon, R. Tetrahedron 2006, 62, 4563.

56. Eliseev, I. I.; Dar'in, D. V.; Selivanov, S. I.; Lobanov, P. S.; Potekhin, A. A. Chem. Heterocycl. Compd. 2008, 44, 442.

57. Listvan, V. N.; Listvan, V. V.; Shekel, A. N. Chem. Heterocycl. Compd. 2002, 38, 1480.

58. Menasra, H.; Kedjadja, A.; Debache, A.; Rhouati, S.; Belfaitah, A.; Carboni, B. Synth. Commun. 2005, 35, 2779.

59. Pokalwar, R. U.; Sadaphal, S. A.; Kategaonkar, A. H.; Shingate, B. B.; Shingare, M. S. Green Chem. Lett. Rev. 2010, 3, 33.

60. Sonar, S. S.; Kategaonkar, A. H.; Ware, M. N.; Gill, C. H.; Shingate, B. B.; Shingare, M. S. Arkivoc 2008, (ii), 138.

61. Mandhane, P. G.; Joshi, R. S.; Nagargoje, D. R.; Gill, C. H. Tetrahedron Lett. 2010, 51, 1490.

62. Sadaphal, S. A.; Sonar, S. S.; Pokalwar, R.; Shitole, N. V.; Shingare, M. J. Korean Chem. Soc. 2009, 53, 536.

63. Sonar, S. S.; Shelke, K. F.; Kakade, G. K.; Shingate, B. B.; Shingare, M. S. Chin. Chem. Lett. 2009, 20,1042.

64. Ramalingam, S.; Kumar, P. Catal. Lett. 2008, 125, 315.

65. Praveen, C.; Karthikeyan, K.; Perumal, P. T. Tetrahedron 2009, 65, 9244.

66. Praveen, C.; Wilson Sagayaraj, Y.; Perumal, P. T. Tetrahedron Lett. 2009, 50, 644.

67. Singh, M. K.; Chandra, A.; Singh, B.; Singh, R. M. Tetrahedron Lett. 2007, 48, 5987.

68. Singh, R. M.; Chandra, A.; Singh, M. K. Synth. Commun. 2007, 37, 1689.

69. (a) Roopan, S. M.; Khan, F. R. N. Arkivoc 2009, (xiii), 161. (b) Aravinda, T.; Naik, H. S. B.; Naik, H. R. P. Int. J. Pep. Res. Ther. 2009, 15, 273.

70. Zeynizadeh, B.; Setamdideh, D. Asian J. Chem. 2009, 21, 3588.

71. Zeynizadeh, B.; Setamdideh, D. J. Chin. Chem. Soc. 2005, 52, 1179.

72. Zeynizadeh, B.; Behyar, T. J. Brazilian Chem. Soc. 2005, 16, 1200.

73. Zeynizadeh, B.; Behyar, T. Bull. Chem. Soc. Jpn. 2005, 78, 307.

74. Zeynizadeh, B.; Behyar. T. Z. Naturforsch. B 2005, 60, 453. 
75. Aravinda, T.; Naik, H. S. B.; Naik, H. R. P.; Abu, V. V. S.; Hemantha, H. P. Int. J. Pep. Res. Ther. 2009, 15, 233.

76. Pokalwar, R. U.; Hangarge, R. V.; Kategaonkar, A. H.; Shingare, M. S. Russ. J. Org. Chem. 2009, 45, 430.

77. China Raju, B.; Suman, P. Chem.-A Eur. J. 2010, 16, 11840.

78. Kidwai, M.; Poddar, R.; Bhardwaj, S.; Singh, S.; Luthra, P. M. Eur. J. Med. Chem. 2010, 45, 5031.

79. Thore, S. N.; Gupta, A. K. Orient. J. Chem. 2010, 26, 613; Chem. Abstr. 2010, 153, 204251.

80. Charris, J. E.; Lobo, G. M.; Camacho, J.; Ferrer, R.; Barazarte, A.; Dominguez, J. N.; Gamboa, N.; Rodrigues, J. R., Angel, J. E. Lett. Drug Design Discov. 2007, 4, 49.

81. Datta, N. J.; Khunt, R. C.; Parikh, A. R. Orient. J. Chem. 2002, $18,131$.

82. Hemasri, Y. Heterocycl. Commun. 2009, 15, 423.

83. Tiwari, V.; Ali, P.; Meshram, J. Int. J. Chem. Tech. Res. 2010, 2, 1031.

84. Bawa, S.; Kumar, S.; Drabu, S.; Panda, B. P.; R. Kumar J. Pharm. Bioallied Sci. 2009, 1, 36.

85. Nadaraj, V.; Selvi, S. T. Org. Chem.: Indian J. 2010, 6, 39; Chem. Abstr. 2010, 153, 600641.

86. Dave, S. S.; Ghatole, A. M.; Rahatgaonkar, A. M.; Chorghade, M. S.; Chauhan, P. M. S.; Srivastava, K. Indian J. Chem. 2009, 48B, 1780.

87. Gupta, B.; Agarwal, A. K. Orient. J. Chem. 2009, 25, 381.

88. Azad, M.; Munawar, M. A.; Siddiqui, H. L. J. Appl. Sci. 2007, 7, 2485.

89. Kalluraya, B.; Gururaja, R.; Rai, G. Indian J. Chem. 2003, 42B, 211.

90. Nakum, S. D.; Pavagadhi, T. H.; Shah, V. H. Indian J. Heterocycl. Chem. 2002, 12, 75.

91. Kumar, N. V.; Rajendran, S. P. Asian J. Chem. 2003, 15, 111.

92. Bulbule, V. J.; Jnaneshwara, G. K.; Deshmukh, R. R.; Borate, H. B.; Deshpande, V. H. Synth. Commun. 2001, 31, 3623.

93. Selvi, S. T.; Mohan, P. S. Indian J. Chem. 2000, 39B, 703.

94. Ladani, N. K.; Patel, M. P.; Patel, R. G. Phosphorus, Sulfur, Silicon, Relat. Elem. 2010, $185,658$.

95. Ladani, N. K.; Patel, M. P.; Patel, R. G. Indian J. Chem. 2009, 48B, 261.

96. Volovnenko, T. A.; Tarasov A. V.; Zubatyuk, R. I.; Shishkin, O. V.; Turov, A. V.; Volovenko, Yu. M. Chem. Heterocycl. Cpd. 2009, 45, 1489.

97. Kidwai, M.; Saxena, S.; Mohan, R. J. Heterocycl. Chem. 2005, 42, 703.

98. Shah, N. K.; Patel, M. P.; Patel, R. G. Phosphorus, Sulfur, Silicon, Relat. Elem. 2009, 184, 2704.

99. Prakash Naik, H. R.; Bhojya Naik, H. S.; Aravinda, T. Afr. J. Pure Appl. Chem. 2009, 3, 202.

100. Nakum, S. D.; Shah, V. H. J. Inst. Chem. 2001, 73, 100.

101. Kidwai, M.; Saxena, S.; Mohan, R. Russ J. Org. Chem. 2006, 42, 52. 
102. Ladani, N. K.; Patel, M. P.; Patel, R. G. Arkivoc 2009, (vii), 292.

103. Kidwai, M.; Saxena, S.; Khan, M. K. R.; Thukral, S. S. Eur. J. Med. Chem. 2005, 40, 816.

104. Ramalingam, S.; Kumar, P. Synth. Commun. 2009, 39, 1299.

105. Gupta, R.; Paul, S.; Gupta, R. J. Mol. Catal. A: Chem. 2007, 266, 50.

106. Gupta, R.; Gupta, M.; Paul, S.; Gupta, R. Can. J. Chem. 2007, 85, 197.

107. Kategaonkar, A. H.; Sadaphal, S. A.; Shelke, K. F.; Shingate, B. B.; Shingare, M. S. Ukr. Bioorg. Acta 2009, 7, 3; Chem. Abstr. 2010, 153, 204298.

108. Kidwai, M.; Singhal, K.; Kukreja, S. Z. Naturforsch.B: Chem. Sci. 2007, 62, 732.

109. Patel, N. A.; Patel, R. G.; Patel, M. P. J. Envir. Res. Devel. 2009, 3, 851.

110. Nirmal, J. P.; Patel, M. P.; Patel, R. G. Indian J. Chem. 2009, 48B, 712.

111. Selvam, N. P.; Perumal, P. T. Arkivoc 2009, (x), 265.

112. Dominguez, J. N.; Leon, C.; Rodrigues, J.; Gamboa de Dominguez, N.; Gut, J.; Rosenthal, P. J. Eur. J. Med. Chem. 2009, 44, 1457.

113. Virsodia, V.; Manvar, A.; Upadhyay, K.; Loriya, R.; Karia, D.; Jaggi, M.; Singh, A.; Mukherjee, R.; Shaikh, M. S.; Coutinho, E. C.; Shah, A. Eur. J. Med. Chem. 2009, 44, 1355.

114. Vijayalakshmi, S.; Prabhavathi, S. Indian J. Heterocycl. Chem. 2008, 18, 149.

115. Ramalingam, S.; Kumar, P. Catal. Commun. 2008, 9, 2445.

116. Kakade, G. K.; Madje, B. R.; Pokalwar, R. U.; Ware, M. N.; Shingare, M. S. Indian J. Heterocycl. Chem. 2008, 17, 379.

117. Kiran, B. M.; Nandeshwarappa, B. P.; Vaidya, V. P.; Mahadevan, K. M. Phosphorus, Sulfur, Silicon, Relat. Elem. 2007, 182, 969.

118. Raghavendra, M.; Naik, H. S. B.; Sherigara, B. S. J. Sulfur Chem. 2006, 27, 347.

119. Charris, J.; Solana, M.; Dominguez, J.; Lobo, G.; Barazarte, A.; Gamboa, N.; Rodrigues, J.; Monasterios, M.; Angel, J.; Migliore, B. Ciencia 2007, 15, 109.

120. Wilson, J. M.; Henderson, G.; Black, F.; Sutherland, A.; Ludwig, R. L.; Vousden, K. H.; Robins, D. J. Bioorg. Med. Chem. 2007, 15, 77.

121. Kidwai, M.; Saxena, S. Synth. Commun. 2006, 36, 2737.

122. Kidwai, M.; Saxena, S.; Rahman Khan, M. K.; Thukral, S. S. Bioorg. Med. Chem. Lett. 2005, 15, 4295.

123. Kantevari, S.; Vuppalapati, S. V. N.; Bantu, R.; Nagarapu, L. J. Heterocycl. Chem. 2010, 47, 313.

124. Kidwai, M.; Singhal, K. Can. J. Chem. 2007, 85, 400.

125. 125.Raghavendra, M.; Naik, H. S. B.; Naik, T. R. R.; Sherigara, B. S. J. Sulfur Chem. 2007, 28, 165.

126. Selvi ,S. T.; Nadaraj, V.; Mohan, S.; Sasi, R.; Hema, M. Bioorg. Med. Chem. 2006, 14, 3896.

127. Paul, S.; Gupta, M.; Gupta, R.; Loupy, A. Tetrahedron Lett. 2001, 42, 3827.

128. Naik, H. R. P.; Naik, H. S. B.; Naik, T. R. R.; Naik, H. R.; Lamani, D. S.; Aravinda, T. J. Sulfur Chem. 2008, 29, 583. 
129. Selvi, S. T.; Nadaraj, V.; Mohan, S.; Sasi, R.; Hema, M. Bioorg. Med. Chem. 2006, 14, 3896.

130. Kedjadja, A.; Moussaoui, F.; Debache, A.; Rhouati, S.; Belfaitah, A. J. Soc. Alger. Chim. 2004, 14, 225.

131. Kumar, R. N.; Suresh, T.; Mohan, P. S. Indian J. Chem. 2003, 42B, 688.

132. Suresh, T.; Kumar, R. N.; Magesh, S.; Mohan, P. S. Indian J. Chem. 2003, 42B, 2133.

133. Afghan, A.; Baradarani, M. M.; Joule, J. A. Arkivoc 2008, (ii), 20.

134. Srivastava, A.; Singh, M. K.; Singh, R. M. Indian J. Chem. 2006, 45B, 292.

135. Lamani, D. S.; Venugopala Reddy, K. R.; Bhojya Naik, H. S.; Savyasachi, A.; Naik, H. R. Nucleos., Nucleot., Nucl., 2008, 27, 1197.

136. Mogilaiah, K.; Sudhakar, G. R.; Reddy, N. V. Indian J. Chem. 2003, 42B, 1753.

137. Dubey, P. K.; Rao, S. S.; Aparna, V. Heterocycl. Commun. 2003, 9, 281.

138. Kidwai, M.; Singhal, K.; Thakur, R. Lett. Org. Chem. 2005, 2, 419.

139. Raghavendra, M.; Naik, H. S. B.; Sherigara, B. S. Arkivoc 2006, (xv), 153.

140. Gururaja, R.; Hegde, J. C.; Vagdevi, H. M.; Kalluraya, B. Indian J. Heterocycl. Chem., 2004, 14, 97.

141. Ukhin, L. Yu.; Kuz'mina, L. G. Russ. Chem. Bull. 2006, 55, 1229.

142. Joshi, S. D.; Joshi, A.; Vagdevi, H. M.; Vaidya, V. P.; Gadaginamath, G. S. Indian J. Heterocycl. Chem. 2010, 19, 221.

143. Nayak, J.; Girish, K. S.; Babu, M.; Kalluraya, B. Indian J. Heterocycl. Chem. 2009, 19, 105.

144. Nagaraja, G. K.; Prakash, G. K.; Kumaraswamy, M. N.; Vaidya, V. P.; Mahadevan, K. M. ARKIVOC 2006, (xv), 160.

145. Amir, M. Orient. J. Chem. 2001, 17, 219.

146. Bhovi, V. K.; Bodke, Y. D.; Biradar, S.; Swamy, B. E. K.; Umesh, S. Phosphorus, Sulfur, Silicon, Relat. Elem. 2010, 185, 110.

147. Dubey, P. K.; Naidu, A.; Kumar, K. S. Org. Chem.: Indian J. 2008, 4, 475.

148. Sonar, S. S.; Sadaphal, S. A.; Labade, V. B.; Shingate, B. B.; Shingare, M. S. Phosphorus, Sulfur, Silicon, Relat. Elem. 2010, 185, 65.

149. Kumar, R. N.; Suresh, T.; Mohan, P. S. J. Indian Chem. Soc. 2002, 79, 774.

150. Sonar, S. S.; Sadaphal, S. A.; Pawar, S. S.; Shingate, B. B.; Shingare, M. S. Chin. Chem. Lett. 2009, 20, 557.

151. Lamani, D. S.; Venugopala Reddy, K. R.; Bhojya Naik, H. S.; Prakash Naik, H. R.; Naik, L. R. J. Sulfur. Chem. 2010, 31, 49.

152. Datta, N. J.; Khunt, R. C.; Parikh, A. R. Indian J. Chem. 2002, 41B, 433.

153. Sampathkumar, N.; Venkatesh Kumar, N.; Rajendran, S. P. Synth. Commun. 2004, 34, 2019.

154. Jia, Z.; Wei, S.; Zhu, Q. Peop. Rep. China. Biol. Pharm. Bull. 2010, 33, 725.

155. Gaddam, V.; Ramesh, S.; Nagarajan, R. Tetrahedron 2010, 66, 4218. 
156. Pokalwar, R. U.; Hangarge, R. V.; Madje, B. R.; Ware, M. N.; Shingare, M. S. Phosphorus, Sulfur, Silicon, Relat. Elem. 2008, 183, 1461.

157. Gupta, M.; Paul, S.; Gupta, R. Indian J. Chem. 2010, 49B, 475.

158. Naik, H. R. P.; Naik, H. S. B.; Aravinda, T.; Lamani, D. S. Nucleosides, Nucleotides, Nucleic Acids, 2010, 29, 39.

159. Abonia, R.; Castillo, J.; Cuervo, P.; Insuasty, B.; Quiroga, J.; Ortiz, A.; Nogueras, M.; Cobo, J. Eur. J. Org. Chem. 2010, 2, 317.

160. Raghavendra, M.; Naik, H. S. B.; Naik, T. R. R.; Sherigara, B. S. J. Sulfur Chem. 2007, 28, 165.

161. Thakor, S. F.; Patel, D. M.; Patel, M. P.; Patel, R. G. Saudi Pharm. J. 2007, 15, 48.

162. El-Sayed, O. A.; Aboul-Enein, H. Y. Arch. Pharm. 2001, 334, 117.

163. Savitha, G.; Perumal, P. T. Tetrahedron Lett. 2006, 47, 3589.

164. Nagaraja, G. K.; Prakash, G. K.; Vaidya, V. P.; Mahadevan, K. M. Indian J. Heterocycl. Chem. 2006, 15, 311.

165. Kalluraya, B.; Nayak, J.; Vagdevi, H. M. Indian J. Heterocycl. Chem. 2005, 14, 257.

166. Gupta, R.; Gupta, A. K.; Paul, S.; Somal, P. Indian J. Chem. 2000, 39B, 847.

167. Sampathkumar, N.; Ramalingam, S. T.; Rajendran, S. P. Indian J. Chem. 2005, 44B, 2608.

168. Pinter, A.; Nyerges, M.; Viranyi, A.; Toke, L. Tetrahedron Lett. 2003, 44, 2343.

169. Augustine, J. K.; Atta, R. N.; Ramappa, B. K.; Boodappa, C. Synlett 2009, 20, 3378.

170. Upadhyay, S.; Chandra, A.; Singh, R. M. Indian J. Chem. 2009, 48B,152.

171. Belmont, P.; Andrez, J.-C.; Allan, C. S. M. Tetrahedron Lett. 2004, 45, 2783.

172. Belmont, P.; Belhadj, T. Org. Lett. 2005, 7, 1793.

173. Kidwai, M.; Saxena, S.; Ruby, R.; Rastogi, S. Bull. Korean Chem. Soc. 2005, 26, 2051.

174. Lebrun, M.-E.; Le Marquand, P.; Berthelette, C. J. Org. Chem. 2006, 71, 2009.

175. Amaravathi, M.; Babu, M. M.; Chandramouli, G. Arkivoc, 2007, (i), 148.

176. Kirpichenok, M. A.; Genis, D. V.; Rodin, O. G.; Solov'ev, A. N.; Kochubei, V. S.; Fedotov, Y. A.; Afanas'ev, I. I. Russ. RU 2284325, 2006;

http://worldwide.espacenet.com/numberSearch?locale=en_EP

177. Trifilenkov, A. S.; Ilyin, A. P.; Kysil, V. M.; Sandulenko, Y. B.; Ivachtchenko, A. V. Tetrahedron Lett. 2007, 48, 2563. 


\section{Authors Biographies}

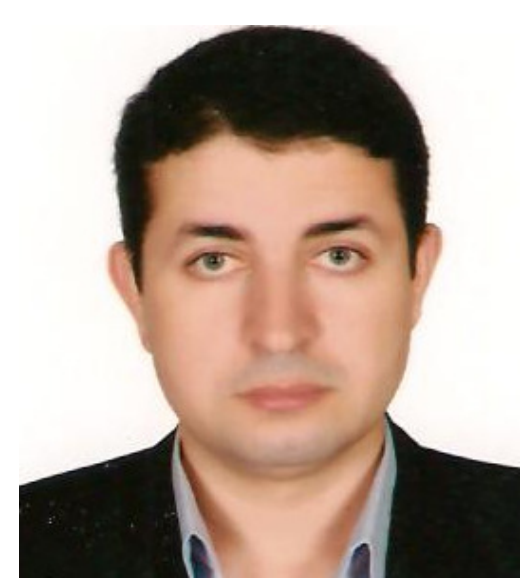

Bakr F. Abdel-Wahab was born in 1978 in Mansoura, Egypt. He is a researcher of organic chemistry at National Research Centre, Giza, Egypt. He has got his B.Sc. in 1999 from Chemistry Department, Faculty of Science, Mansoura University, Egypt. Received his M.Sc. in 2003 from the same University and he awarded his Ph.D. degree in 2007 from Ain-Shams University, Cairo. His current research interests cover the development of organic reactions and their applications in the synthesis of new biologically active heterocycles. He also worked as an assistant professor of organic chemistry at king Abdulaziz University at Saudia Arabia in the peroid from Sept. 2009 to July 2011; and now he returned back to his original work at National Research Centre, Dokki, Giza, Egypt. He has already published about 38 scientific papers, reviews and chapter in books in various distinguished international journals.

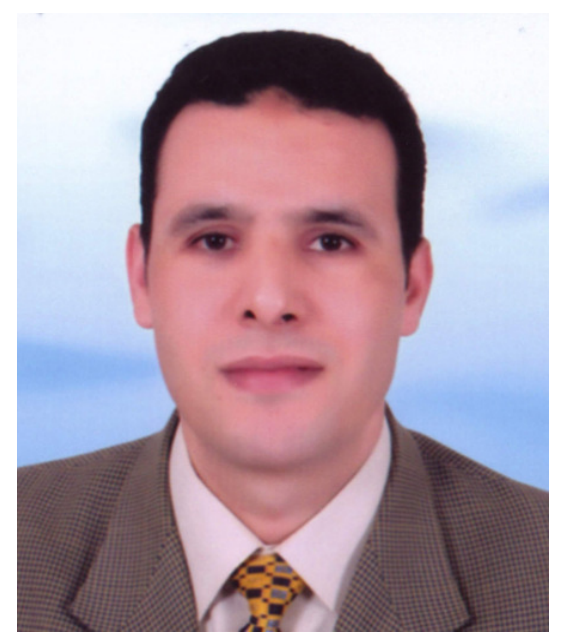

Rizk E. khidre is a researcher of organic chemistry at National Research Centre, Giza, Egypt. He was born in 1974 in Mansoura, Egypt and received both B.S. degree (1996) and M.S. degree (2002) from Mansoura University (Professor A. H. Abdel-Rahman), and his Ph.D. degree from Ain-Shams University, Cairo under supervision of Professor Mounir A. I. Salem and Professor Wafaa M. Abdou (D.Sc). He received his PhD in 2009 in "Synthesis of Pharmaceutically Active Nitrogen-Heterocycles and Their Relevant Phosphonates. His research interest is the synthesis of 
heterocyclic and organophosphours compounds with pharmaceutical interest using a variety of phosphorus reagents. Since 2010 he is associate professor of organic chemistry, Faulty of Science, Jazan University, Saudi Arabia.

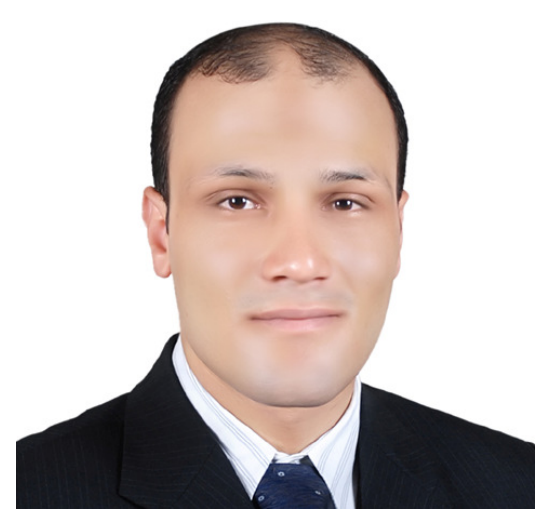

Abdelbasset A. Farahat was born in 1980 in Mansoura, Egypt. He is a post doc. Researcher of Medicinal Chemistry at Georgia State University, Atlanta, Georgia, USA. He has got his B.Sc. in 2002 from Faculty of Pharmacy, Mansoura University, Egypt. He received his M.Sc. in 2006 from Pharmaceutical Organic Chemistry Department, Faculty of Pharmacy, Mansoura University, under the supervision of Professor Hassan M. Eissa. He has awarded his Ph.D. degree in 2010 after a joint program between Mansoura University and Georgia State University, Atlanta, Georgia, USA, under the supervision of Professor David W. Boykin. He is working now in A GATES and NIH funded projects entitled, "Drug discovery for parasitic diseases" and "Synthesis of G-Recognition Units for DNA Minor-groove Recognition".

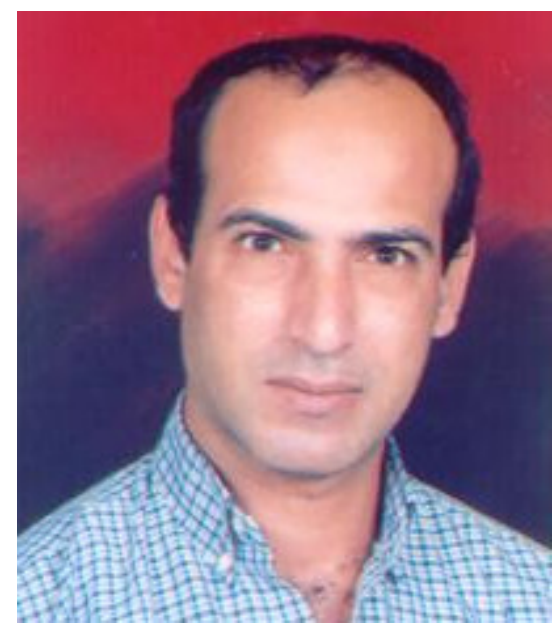

Professor Abdel-Aziz Sayed El-Ahl was born in Mansoura, Egypt in 1958. He received his M. Sc. degree from the University of Mansoura in1985 under the supervision of Professor A. M. Khalil. He performed his Ph.D. thesis on model studies for synthesis of mitomycin $\mathrm{C}$ in the research group of Professor H. J. Knoelker in Hannover, Germany under the scientific channel system between Egypt and Germany where he graduated in 1992. Since 1992, he has been a 
lecturer at theUniversity of Mansoura, Egypt. In 1997 he has became associate professor at the same institution. Professor A. S. El-Ahl has awarded the Fulbright fellowship January 1998- July 1998 to join the group of Professor William A. Donaldson for studying the application of tricarbnyliron diene complexes in synthesis of Macrolactin A at the chemistry department, Marquette University, Milwaukee, Wisconsin, USA. Since 2002 he moved to the chemistry department, University College Makkah, Umm Al-Qura University, Makkah, Saudi Arabia and he was promoted to full professor in 2004. His research interest is the synthesis of heterocyclic compounds with pharmaceutical interest using a variety of Silicon reagents derived from tetrachlorosilane and soft nucleophiles. 